Prepared in cooperation with the Oregon Water Resources Department

\title{
Simulation of Groundwater and Surface-Water Flow in the Upper Deschutes Basin, Oregon
}

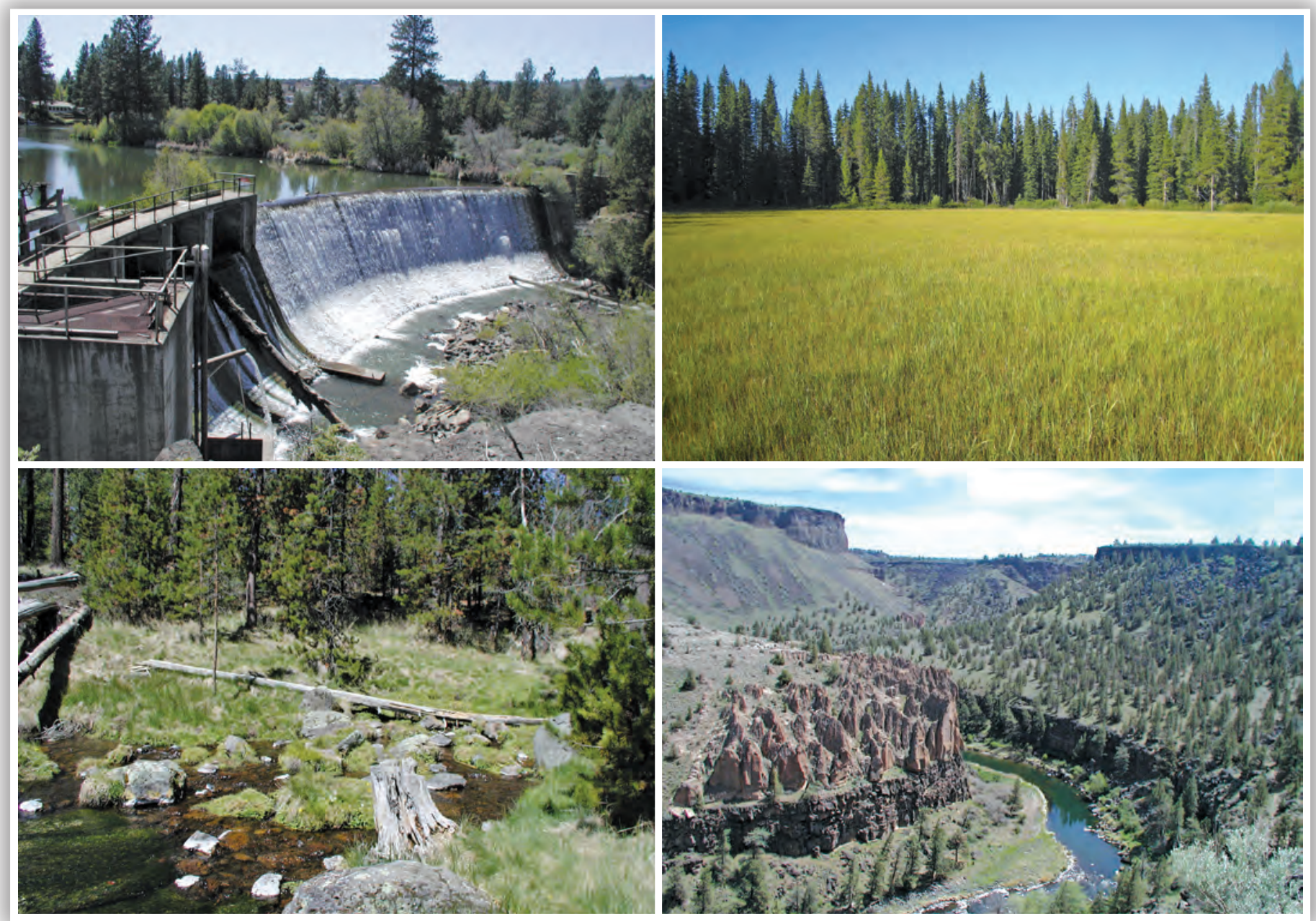

Scientific Investigations Report 2017-5097 


\section{Cover:}

Upper left: Irrigation diversion dam on the Deschutes River in Bend, Oregon,

May, 2002.

Upper right: Groundwater-fed wetland between Cultus Lake and Crane Prairie Reservoir, August 2012.

Lower left: Headwater spring feeding Fall River, Oregon, May 2002.

Lower right: Strata of the Deschutes Formation and overlying lavas exposed along the Crooked River, May 2002.

All photographs by Marshall Gannett, U.S. Geological Survey. 


\section{Simulation of Groundwater and Surface-Water Flow in the Upper Deschutes Basin, Oregon}

By Marshall W. Gannett, Kenneth E. Lite, Jr., John C. Risley, Esther M. Pischel, and Jonathan L. La Marche

Prepared in cooperation with the Oregon Water Resources Department

Scientific-Investigations Report 2017-5097 


\title{
U.S. Department of the Interior \\ RYAN K. ZINKE, Secretary
}

\section{U.S. Geological Survey William H. Werkheiser, Acting Director}

\author{
U.S. Geological Survey, Reston, Virginia: 2017
}

For more information on the USGS - the Federal source for science about the Earth, its natural and living resources, natural hazards, and the environment-visit https://www.usgs.gov or call 1-888-ASK-USGS.

For an overview of USGS information products, including maps, imagery, and publications, visit https://store.usgs.gov.

Any use of trade, firm, or product names is for descriptive purposes only and does not imply endorsement by the U.S. Government.

Although this information product, for the most part, is in the public domain, it also may contain copyrighted materials as noted in the text. Permission to reproduce copyrighted items must be secured from the copyright owner.

Suggested citation:

Gannett, M.W., Lite, K.E., Jr., Risley, J.C., Pischel, E.M., and La Marche, J.L., 2017, Simulation of groundwater and surface-water flow in the upper Deschutes Basin, Oregon: U.S. Geological Survey Scientific Investigations Report 2017-5097, 68 p., https://doi.org/10.3133/sir20175097.

ISSN 2328-0328 (online) 


\section{Contents}

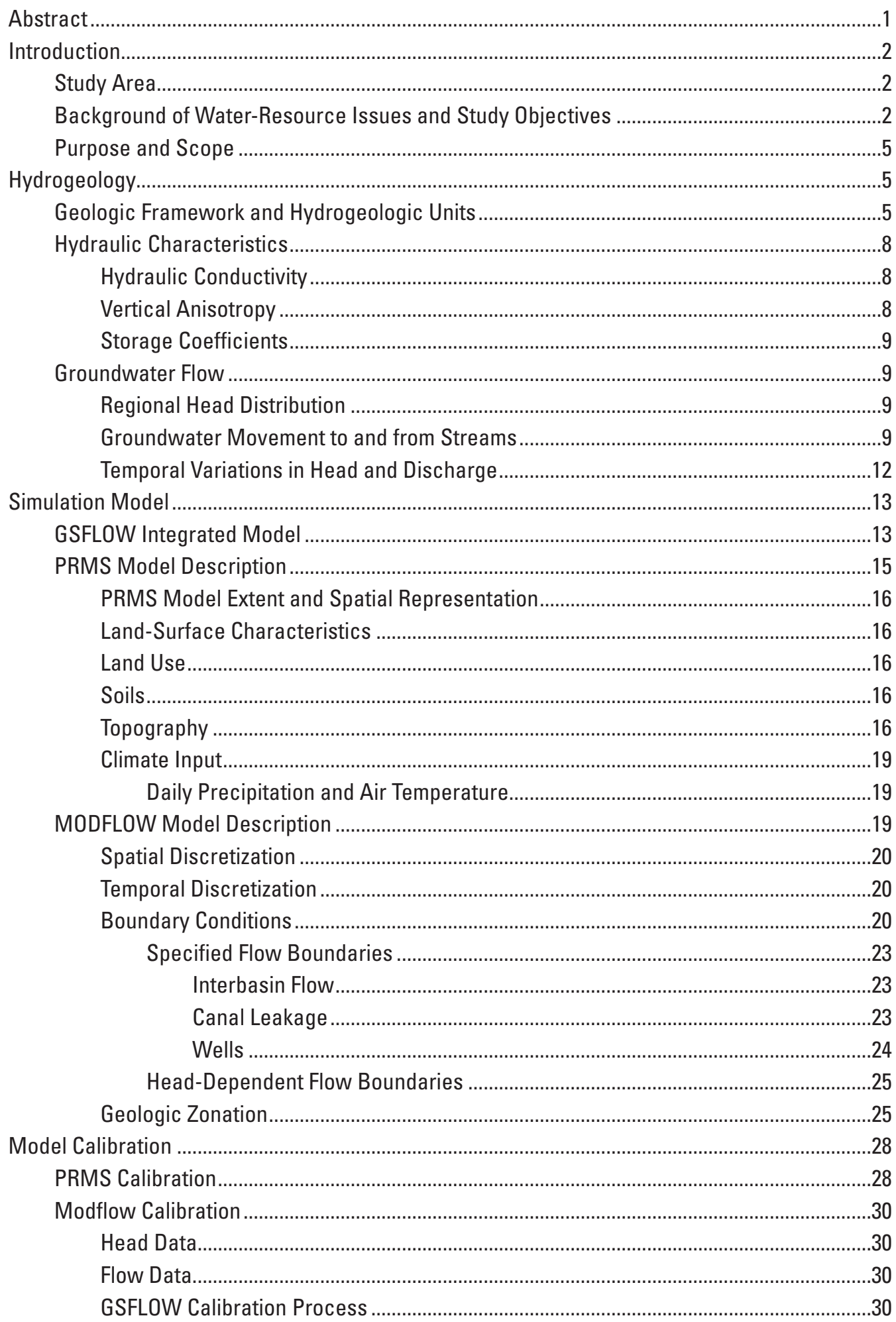




\section{Contents-Continued}

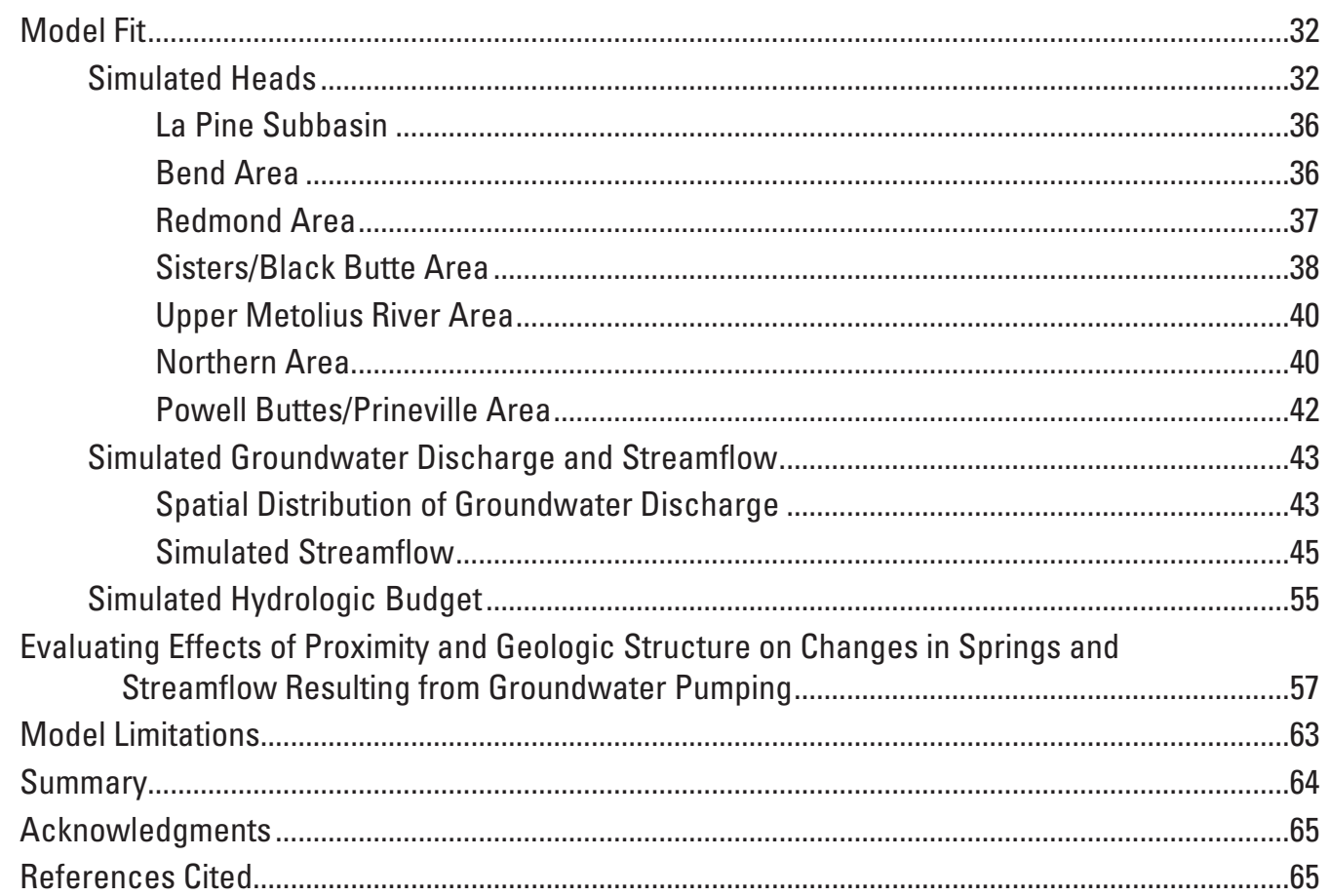

\section{Figures}

1. Map showing major geographic features in the upper Deschutes Basin, Oregon...........3

2. Map showing mean annual precipitation in the upper Deschutes Basin, Oregon, 1981-2010

3. Map showing hydrogeologic units and major faults in the upper Deschutes Basin, Oregon

4. Map showing the generalized water-table elevation in the upper Deschutes Basin, Oregon

5. Map showing distribution of stream gains due to groundwater discharge and stream losses due to seepage to underlying aquifers, upper Deschutes Basin, Oregon

6. Schematic diagram showing the exchange of flow among the three regions in GSFLOW

7. Map showing MODFLOW grid and boundary conditions and active PRMS hydrologic response units for GSFLOW model, upper Deschutes Basin, Oregon

8. Schematic diagram of Precipitation Runoff Modeling System climate inputs, watershed components, and flow paths

9. Model cross sections showing vertical discretization, upper Deschutes Basin, Oregon

10. Map showing zonation of hydrogeology used in the MODFLOW model, upper Deschutes Basin, Oregon.

11. Map showing head observation wells used for model calibration, upper Deschutes Basin, Oregon 


\section{Figures-Continue}

12. Graph showing simulated heads as a function of measured heads, 1980-2013, upper Deschutes Basin, Oregon ..

13. Graph showing head residuals as a function of measured heads, 1980-2013, upper Deschutes Basin, Oregon

14. Map of head residuals averaged for each observation well, upper Deschutes Basin, Oregon,model layers 1-2, model layers 3-8. MODFLOW, modular groundwater flow model.

15. Graph showing measured and simulated water levels in observation well 20S/10E-01DCA in the La Pine subbasin, Oregon

16. Graph showing measured and simulated water levels in observation well 17S/12E-23BBC near Bend, Oregon

17. Graphs showing measured and simulated water levels in observation wells 15S/13E-18ADD1 and 15S/13E-21ADB near Redmond, Oregon.

18. Graph showing measured and simulated water levels in observation well 14S/12E-09ACB near Lower Bridge, upper Deschutes Basin, Oregon

19. Graphs showing measured and simulated water levels observation wells 15S/10E-08ACD and 15S/10E-02CDA near Sisters, Oregon.

20. Graph showing measured and simulated water levels in observation well 14S/09E-08ABA near Black Butte, Oregon

21. Graph showing measured and simulated water levels in observation well 13S/09E-03AAC3 in the upper Metolius River Basin near Camp Sherman, Oregon

22. Graph showing measured and simulated water levels in observation well $11 \mathrm{~S} / 13 \mathrm{E}-24 \mathrm{BCD}$ east of Madras, Oregon

23. Graphs showing measured and simulated water levels in observation wells 15S/14E-23CAD $(A)$ and 15S/15E-03BA $(B)$ near Powell Butte, Oregon

24. Map showing spatial distribution of simulated groundwater discharge to streams, December 2013, and locations of selected streamgage locations, upper Deschutes Basin, Oregon

25. Graph showing simulated and naturalized daily mean flows of the Deschutes River near Madras, Oregon

26. Graph showing simulated and naturalized mean-monthly flows and mean-annual flows of the Deschutes River near Madras, Oregon

27. Graph showing simulated and gaged daily mean flows of the Metolius River near Grandview, Oregon

28. Graphs showing simulated and gaged mean-monthly flows and mean-annual flows of the Metolius River near Grandview, Oregon

29. Graph showing simulated and naturalized daily mean flows of the Crooked River below Opal Springs, Oregon

30. Graphs showing simulated and naturalized mean-monthly and mean-annual flows of the Crooked River below Opal Springs, Oregon

31. Graph showing simulated and naturalized daily mean flows of the Deschutes River near Culver, Oregon.

32. Graphs showing simulated and naturalized mean-monthly flows and mean-annual flows of the Deschutes River near Culver, Oregon

33. Graphs showing simulated and gaged mean-monthly flows and mean-annual flows of Whychus Creek near Sisters, Oregon 


\section{Figures-Continued}

34. Graphs showing simulated and naturalized mean-monthly flows and mean-annual flows of the Deschutes River near Benham Falls, Oregon

35. Graphs showing simulated and naturalized mean-annual flows of the Deschutes River below Wickiup Reservoir, Oregon

36. Graphs showing simulated and naturalized mean-monthly flows and mean-annual flows of the Little Deschutes River near La Pine, Oregon

37. Graphs showing simulated and gaged mean-monthly flows and mean-annual flows of Odell Creek near La Pine.....

38. Graph showing monthly average simulated components of the hydrologic budget, upper Deschutes Basin, Oregon....

39. Graph showing simulated monthly average components of streamflow, upper Deschutes Basin, Oregon

40. Map showing simulated average annual depletion of groundwater discharge to stream cells after 14 years of pumping 20 cubic feet per second April through October from a well about 3 miles east-southeast of Sisters, Oregon

41. Graph showing simulated depletion of streamflow to heavily affected stream reaches from pumping a well about 3 miles east-southeast of Sisters, Oregon

42. Map showing simulated average annual depletion of groundwater discharge to stream cells after 14 years of pumping 20 cubic feet per second April through October from a well about 3 miles south-southwest of Black Butte, Oregon....

43. Graph showing simulated depletion of streamflow to heavily affected stream reaches from pumping a well about 3 miles south-southwest of Black Butte, Oregon

44. Map showing simulated average annual depletion of groundwater discharge to stream cells after 14 years of pumping 20 cubic feet per second April through October from a well about 6.5 miles east-northeast of Sisters, Oregon

45. Graphs showing simulated depletion of streamflow to heavily affected stream reaches due to pumping a well about 6.5 miles east-northeast of Sisters, Oregon..

\section{Tables}

1. Names, numbers, areas, and anthropogenic impacts of subbasins used in the PRMS model

2. Precipitation Runoff Modeling System model parameter values determined from geospatial data or not at default values

3. Final MODFLOW parameter values and descriptions of MODFLOW zones used in the upper Deschutes Basin, Oregon, GSFLOW model

4. Sources of snowpack and solar radiation measurements used to calibrate the PRMS model, upper Deschutes Basin, Oregon.

5. Simulated and observed (gaged or naturalized) flows at selected USGS streamgages in the upper Deschutes Basin, Oregon. 


\section{Conversion Factors}

U.S. customary units to International System of Units

\begin{tabular}{|c|c|c|}
\hline Multiply & By & To obtain \\
\hline \multicolumn{3}{|c|}{ Length } \\
\hline inch (in.) & 2.54 & centimeter (cm) \\
\hline inch (in.) & 25.4 & millimeter (mm) \\
\hline foot (ft) & 0.3048 & meter (m) \\
\hline mile (mi) & 1.609 & kilometer (km) \\
\hline \multicolumn{3}{|c|}{ Area } \\
\hline square foot $\left(\mathrm{ft}^{2}\right)$ & 929.0 & square centimeter $\left(\mathrm{cm}^{2}\right)$ \\
\hline square foot $\left(\mathrm{ft}^{2}\right)$ & 0.09290 & square meter $\left(\mathrm{m}^{2}\right)$ \\
\hline square mile $\left(\mathrm{mi}^{2}\right)$ & 259.0 & hectare (ha) \\
\hline square mile $\left(\mathrm{mi}^{2}\right)$ & 2.590 & square kilometer $\left(\mathrm{km}^{2}\right)$ \\
\hline \multicolumn{3}{|c|}{ Volume } \\
\hline cubic foot $\left(\mathrm{ft}^{3}\right)$ & 28.32 & cubic decimeter $\left(\mathrm{dm}^{3}\right)$ \\
\hline cubic foot $\left(\mathrm{ft}^{3}\right)$ & 0.02832 & cubic meter $\left(\mathrm{m}^{3}\right)$ \\
\hline \multicolumn{3}{|c|}{ Flow rate } \\
\hline acre-foot per year (acre-ft/yr) & 1,233 & cubic meter per year $\left(\mathrm{m}^{3} / \mathrm{yr}\right)$ \\
\hline acre-foot per year (acre-ft/yr) & 0.001233 & cubic hectometer per year $\left(\mathrm{hm}^{3} / \mathrm{yr}\right)$ \\
\hline foot per day (ft/d) & 0.3048 & meter per day $(\mathrm{m} / \mathrm{d})$ \\
\hline cubic foot per second $\left(\mathrm{ft}^{3} / \mathrm{s}\right)$ & 0.02832 & cubic meter per second $\left(\mathrm{m}^{3} / \mathrm{s}\right)$ \\
\hline cubic foot per day $\left(\mathrm{ft}^{3} / \mathrm{d}\right)$ & 0.02832 & cubic meter per day $\left(\mathrm{m}^{3} / \mathrm{d}\right)$ \\
\hline gallon per minute (gal/min) & 0.06309 & liter per second (L/s) \\
\hline inch per year (in/yr) & 25.4 & millimeter per year (mm/yr) \\
\hline \multicolumn{3}{|c|}{ Hydraulic conductivity } \\
\hline foot per day (ft/d) & 0.3048 & meter per day (m/d) \\
\hline \multicolumn{3}{|c|}{ Transmissivity } \\
\hline foot squared per day ( $\left.\mathrm{ft}^{2} / \mathrm{d}\right)$ & 0.09290 & meter squared per day (m²/d) \\
\hline \multicolumn{3}{|c|}{ Leakance } \\
\hline foot per day per foot ([ft/d]/ft) & 1 & meter per day per meter $([\mathrm{m} / \mathrm{d}] / \mathrm{m})$ \\
\hline
\end{tabular}

Temperature in degrees Celsius $\left({ }^{\circ} \mathrm{C}\right)$ may be converted to degrees Fahrenheit $\left({ }^{\circ} \mathrm{F}\right)$ as follows:

$$
{ }^{\circ} \mathrm{F}=\left(1.8 \times{ }^{\circ} \mathrm{C}\right)+32
$$

Temperature in degrees Fahrenheit $\left({ }^{\circ} \mathrm{F}\right)$ may be converted to degrees Celsius $\left({ }^{\circ} \mathrm{C}\right)$ as follows:

$$
{ }^{\circ} \mathrm{C}=\left({ }^{\circ} \mathrm{F}-32\right) / 1.8 .
$$




\section{Datums}

Vertical coordinate information is referenced to the National Geodetic Vertical Datum of 1929 (NGVD 29).

Horizontal coordinate information is referenced to the, North American Datum of 1983 (NAD 83).

Elevation, as used in this report, refers to distance above the vertical datum.

\section{Supplemental Information}

Transmissivity: The standard unit for transmissivity is cubic foot per day per square foot times foot of aquifer thickness ([ft $\left.\left.{ }^{3} / \mathrm{d}\right] / \mathrm{ft}^{2}\right)$. In this report, the mathematically reduced form, foot squared per day ( $\left.\mathrm{ft}^{2} / \mathrm{d}\right)$, is used for convenience. 


\title{
Simulation of Groundwater and Surface-Water Flow in the Upper Deschutes Basin, Oregon
}

\author{
By Marshall W. Gannett', Kenneth E. Lite, Jr. ${ }^{2}$, John C. Risley', Esther M. Pischel', and Jonathan L. La Marche ${ }^{2}$
}

\section{Abstract}

This report describes a hydrologic model for the upper Deschutes Basin in central Oregon developed using the U.S. Geological Survey (USGS) integrated Groundwater and Surface-Water Flow model (GSFLOW). The upper Deschutes Basin, which drains much of the eastern side of the Cascade Range in Oregon, is underlain by large areas of permeable volcanic rock. That permeability, in combination with the large annual precipitation at high elevations, results in a substantial regional aquifer system and a stream system that is heavily groundwater dominated.

The upper Deschutes Basin is also an area of expanding population and increasing water demand for public supply and agriculture. Surface water was largely developed for agricultural use by the mid-20th century, and is closed to additional appropriations. Consequently, water users look to groundwater to satisfy the growing demand. The well-documented connection between groundwater and the stream system, and the institutional and legal restrictions on streamflow depletion by wells, resulted in the Oregon Water Resources Department (OWRD) instituting a process whereby additional groundwater pumping can be permitted only if the effects to streams are mitigated, for example, by reducing permitted surface-water diversions. Implementing such a program requires understanding of the spatial and temporal distribution of effects to streams from groundwater pumping. A groundwater model developed in the early 2000s by the USGS and OWRD has been used to provide insights into the distribution of streamflow depletion by wells, but lacks spatial resolution in sensitive headwaters and spring areas.

The integrated model developed for this project, based largely on the earlier model, has a much finer grid spacing allowing resolution of sensitive headwater streams and important spring areas, and simulates a more complete set of surface processes as well as runoff and groundwater flow. In addition, the integrated model includes improved representation of subsurface geology and explicitly simulates the effects of hydrologically important fault zones not included in the previous model.
The upper Deschutes Basin GSFLOW model was calibrated using an iterative trial and error approach using measured water-level elevations (water levels) from 800 wells, 144 of which have time series of 10 or more measurements. Streamflow was calibrated using data from 21 gage locations. At 14 locations where measured flows are heavily influenced by reservoir operations and irrigation diversions, so called "naturalized" flows, with the effects of reservoirs and diversion removed, developed by the Bureau of Reclamation, were used for calibration. Surface energy and moisture processes such as solar radiation, snow accumulation and melting, and evapotranspiration were calibrated using national datasets as well as data from long-term measurement sites in the basin. The calibrated Deschutes GSFLOW model requires daily precipitation, minimum and maximum air temperature data, and monthly data describing groundwater pumping and artificial recharge from leaking irrigation canals (which are a significant source of groundwater recharge).

The calibrated model simulates the geographic distribution of hydraulic head over the 5,000 ft range measured in the basin, with a median absolute residual of about $53 \mathrm{ft}$. Temporal variations in head resulting from climate cycles, pumping, and canal leakage are well simulated over the model area. Simulated daily streamflow matches gaged flows or calculated naturalized flows for streams including the Crooked and Metolius Rivers, and lower parts of the mainstem Deschutes River. Seasonal patterns of runoff are less well fit in some upper basin streams. Annual water balances of streamflow are good over most of the model domain. Model fit and overall capabilities are appropriate for the objectives of the project.

The integrated model results confirm findings from other studies and models indicating that most streamflow in the upper Deschutes Basin comes directly from groundwater discharge. The integrated model provides additional insights about the components of streamflow including direct groundwater discharge to streams, interflow, groundwater discharge to the land surface (Dunnian flow), and direct runoff (Hortonian flow). The new model provides improved capability for exploring the timing and distribution of
${ }^{1}$ U.S. Geological Survey.

${ }^{2}$ Oregon Water Resources Department. 
streamflow capture by wells, and the hydrologic response to changes in other external stresses such as canal operation, irrigation, and drought. Because the model uses basic meteorological data as the primary input; and simulates surface energy and moisture balances, groundwater recharge and flow, and all components of streamflow; it is well suited for exploring the hydrologic response to climate change, although no such simulations are included in this report.

The model was developed as a tool for future application; however, example simulations are provided in this report. In the example simulations, the model is used to explore the influence of well location and geologic structure on stream capture by pumping wells. Wells were simulated at three locations within a 12-mi area close to known groundwater discharge areas and crossed by a regional fault zone.

Simulations indicate that the magnitude and timing of stream capture from pumping is largely controlled by the geographic location of the wells, but that faults can have a large influence on the propagation of pumping stresses.

\section{Introduction}

\section{Study Area}

The upper Deschutes Basin study area spans the part of central Oregon extending eastward from the crest of the Cascade Range to older low-permeability volcanic uplands to the east (fig. 1). The study area encompasses approximately 4,500 $\mathrm{mi}^{2}$ and is drained by the Deschutes River and its major tributaries: the Little Deschutes River, Tumalo and Whychus Creeks, and the Metolius River from the west; and the Crooked River from the east. Land-surface elevation ranges from less than 1,300 ft near Gateway in the northern part of the study area to more than $10,000 \mathrm{ft}$ in the Cascade Range. The study area includes the major population centers in the basin, including Bend, Redmond, Sisters, Madras, Prineville, and La Pine.

The study area boundaries were chosen to coincide as much as possible with natural hydrologic boundaries across which groundwater flow can be reasonably estimated or assumed to be negligible. The study area is bounded on the north by Jefferson Creek, the Metolius River, the Deschutes River, and Trout Creek; on the east by the generalized contact between the Deschutes Formation and the older, much less permeable John Day Formation; on the south by the drainage divide between the Deschutes Basin and the Fort Rock and Klamath Basins; and on the west by the Cascade Range crest.

There are about 169,000 acres irrigated with surface water in the study area. The largest source of irrigation water is the Deschutes River. Irrigation water is stored in Crane Prairie and Wickiup Reservoirs in the southern part of the study area. From the reservoirs, water flows down the
Deschutes River and is diverted near Bend and distributed through several hundred miles of canals. Smaller amounts of irrigation water are diverted from Tumalo and Whychus Creeks, the Crooked River, and Ochoco Creek.

The climate in the Deschutes Basin is controlled primarily by air masses that move eastward from the Pacific Ocean, across western Oregon, and into central Oregon. The climate is moderate, with cool, wet winters and warm, dry summers. Orographic processes result in large amounts of precipitation in the Cascade Range in the western part of the basin, with precipitation locally exceeding 125 inches per year (in/yr), mostly as snow during the winter (Taylor, 1993). Precipitation rates diminish rapidly toward the east to less than $10 \mathrm{in} / \mathrm{yr}$ in the central part of the basin (fig. 2). Climate in the Deschutes Basin, and the resulting hydrology, exhibit yearto-year and longer-term variability. This variability generally parallels regional climate signals in the Pacific Northwest that have been correlated with large-scale, ocean-atmosphere climate variability patterns in the Pacific Basin such as the El Niño/Southern Oscillation (Redmond and Koch, 1991) and the Pacific Decadal Oscillation (Mantua and others, 1997). Recent studies have concluded that general warming in the area is resulting in diminished winter snowpack (Mote and others, 2005; Knowles and others, 2006). Studies have also demonstrated that warming and consequent changes in snowpack will affect the groundwater hydrology (Tague and others, 2008; Waibel and others, 2013). Groundwater level declines measured in wells in the basin since the mid-1990s have been attributed in part to climate-driven reductions in groundwater recharge, in addition to groundwater pumping and canal piping (Gannett and Lite, 2013).

The large amount of precipitation in the Cascade Range combined with the highly permeable Quaternary volcanic rocks results in a substantial regional groundwater system. As a consequence, most streams originating from the Cascade Range are groundwater dominated with very consistent yearround flows relative to the more runoff-dominated streams entering the basin from the east (Gannett and others, 2003).

\section{Background of Water-Resource Issues and Study Objectives}

The upper Deschutes Basin has experienced considerable development and population increase in recent decades, resulting in increased demand for water. Streams in the basin, however, have been closed for further appropriation for many years. As a consequence, water users have turned to groundwater to meet growing demand. Even though streamflow depletion by wells is a common and widely recognized phenomenon (Barlow and Leake, 2012), it is a particular challenge in the upper Deschutes Basin because of the large degree to which streams rely on groundwater discharge and the regulatory protections on streamflow. 


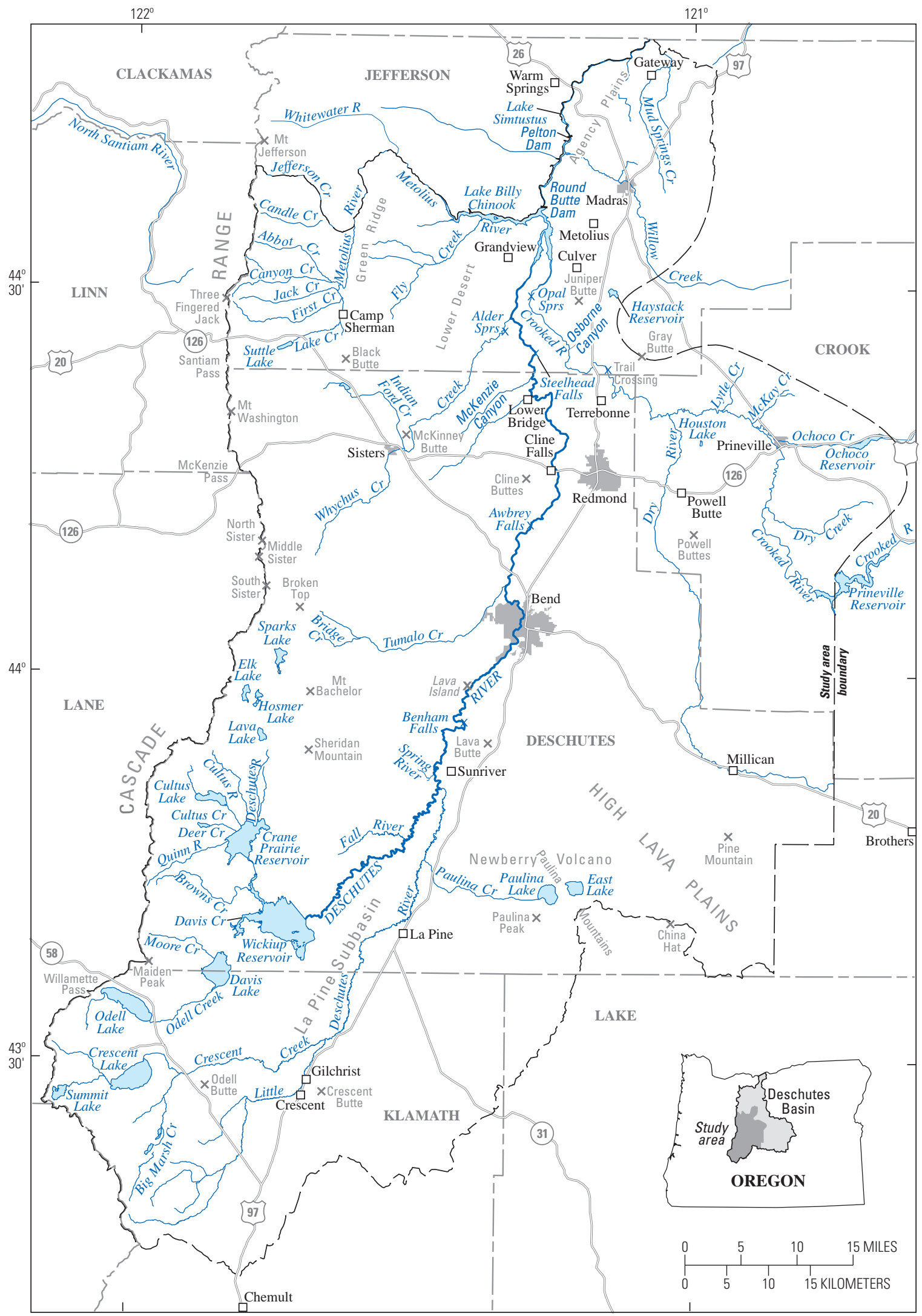

Base modified from U.S. Geological Survey data and other digital sources.

Figure 1. Major geographic features in the upper Deschutes Basin, Oregon. 


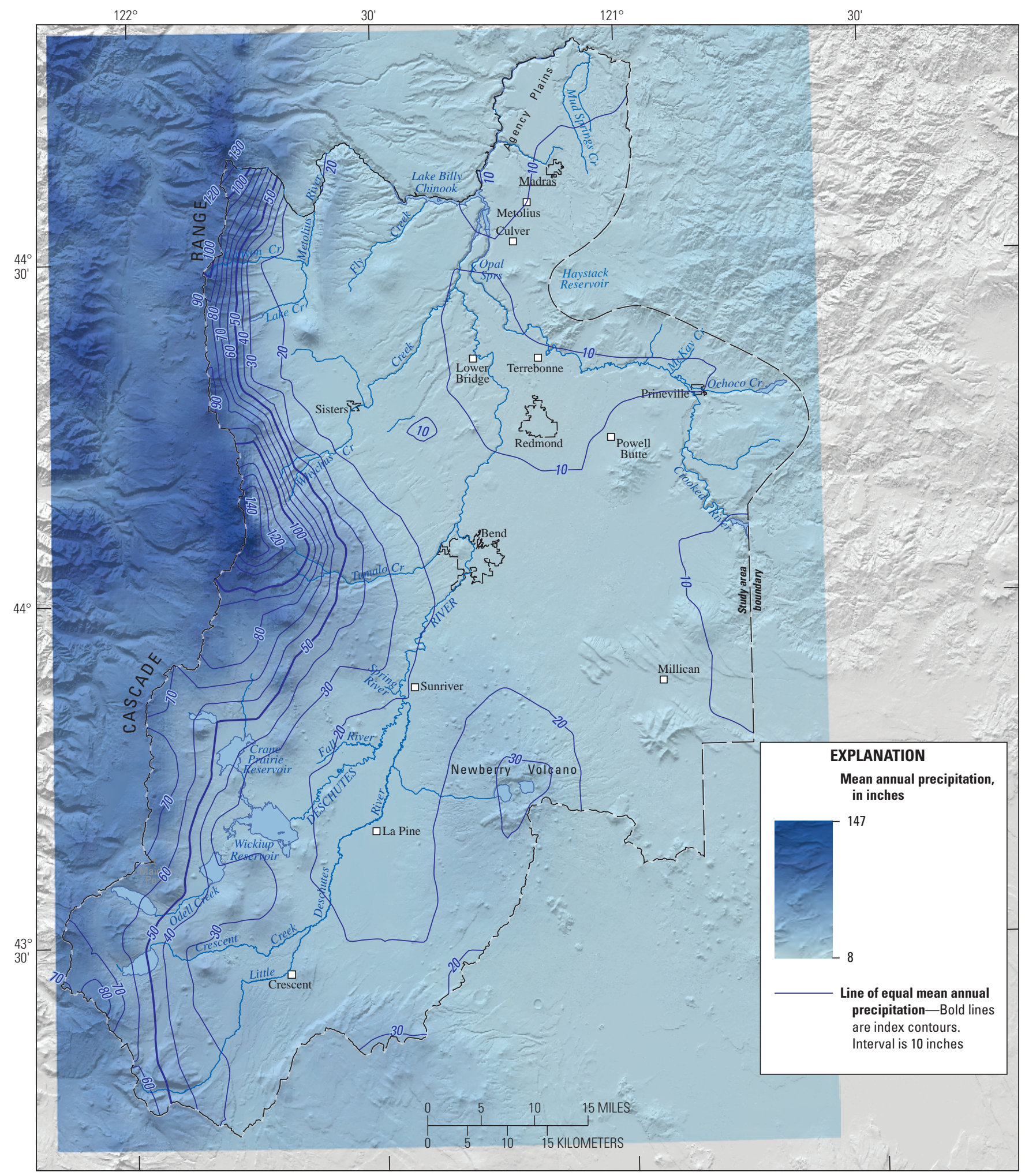

Coordinate reference system: Universal Transverse Mercator Zone

10 North, horizontal datum is North American Datum of 1983.

Figure 2. Mean annual precipitation in the upper Deschutes Basin, Oregon, 1981-2010. Data from PRISM Climate Group (2017). 
To accommodate growing water demand in the basin, and shifting priorities for water, the Oregon Water Resources Department (OWRD) instituted a program in 2002 whereby new groundwater uses can be permitted if the resulting impacts to the stream system are mitigated, for example by retiring a surface-water right (or portion thereof) and offsetting the impact to the affected stream reach. Implementing such a program requires knowledge of the probable magnitude and distribution of groundwater pumping impacts to help ensure mitigation occurs at the correct location. A groundwater flow model for the upper Deschutes Basin developed cooperatively by the U.S. Geological Survey (USGS) and OWRD (Gannett and Lite, 2004) provided useful insights regarding the spatial and temporal distribution of these impacts, and was used to inform development of a mitigation strategy in conjunction with other data and general understanding of the basin hydrology.

Since development of the 2004 groundwater model, there has been increased focus on geographically smaller areas such as specific ecologically important stream reaches or spring complexes. Mitigation of impacts to spring complexes is not part of the current OWRD program, but has been recognized by stakeholders and legislators as a crucial issue. This is particularly important in the northern part of the study area around Sisters and the Metolius River area where private land (and associated commercial or agricultural development potential) is close to potentially vulnerable streams and springs. The 2004 model is not well suited for this more refined-scale analysis because of the coarse spatial discretization in some of the areas of interest including the Cascade Range. The grid spacing of the 2004 model, which is as large as $10,000 \mathrm{ft}$ in some areas, precludes discrimination of individual streams in many locations.

Interest in understanding the possible hydrologic response to projected future climate has also increased. Although the 2004 model has been used to evaluate the spatial variability in response of the groundwater system to projected future climate (Waibel and others, 2013) and the influence of climate on observed water-level declines (Gannett and Lite, 2013), the limitations of the coarse scale were still present. In addition, the 2004 model simulates the groundwater component of streamflow and not other components that are important to the overall response. Moreover, because groundwater recharge was calculated using a separate surface-process model, the Deep Percolation Model (DPM) of Bauer and Vaccaro (1987), using the 2004 groundwater model for future climate simulations requires operation and maintenance of a separate model.

The modeling effort described in this report was intended to address shortcomings of the 2004 model. Specific objectives were to (1) refine the spatial resolution of the groundwater model to allow better representation of streams in the Cascade Range (most importantly the Metolius River); (2) simulate a more complete set of hydrologic and energy processes including snowpack, evapotranspiration, and runoff; (3) update model input datasets such as pumping and canal leakage; and (4) provide for more efficient exploration of the hydrologic response to climate. These objectives were met by developing a coupled groundwater/surface-water model (based on the 2004 model) using the Groundwater and Surface-Water Flow (GSFLOW) modeling environment (Markstrom and others, 2008).

\section{Purpose and Scope}

This report is intended to document the simulation model and provide example applications. Because the model and underlying hydrogeologic framework stem from pre-existing efforts, background information is kept brief and the reader is referred to previous reports as needed. Similarly, discussion of the fundamental aspects of hydrologic modeling is also limited and the reader is referred to basic texts and documentation of modeling systems used in this project.

\section{Hydrogeology}

\section{Geologic Framework and Hydrogeologic Units}

The stratigraphic and structural framework of the upper Deschutes Basin influences many aspects of groundwater recharge, flow, and discharge. Episodic volcanic activity in the region over the past several million years has resulted in a variety of volcanic, volcaniclastic, and volcanically derived sedimentary deposits. The geologic framework of the regional groundwater system in the upper Deschutes Basin is described by Lite and Gannett (2002), in which they defined seven regional hydrogeologic units (fig. 3). The lowermost unit (the Pre-Deschutes Formation deposits) consists of volcanic and volcanic-derived deposits of the Oligocene John Day Formation and Eocene Clarno Formation. This unit has markedly low permeability and is considered the basement of the regional groundwater system except beneath the Cascade Range and Newberry Volcano. The depth to the John Day and Clarno Formations is not well known in the central and western parts of the study area. Mapping shows that where they are exposed, strata in the lower part of the overlying Deschutes Formation are nearly flat-lying with a southward dip of less than 1 degree (Smith, 1986). The elevation of the top of the John Day Formation in the central part of the basin, therefore, is not far below the elevation where it is exposed in canyons in the northern part of the study area. 


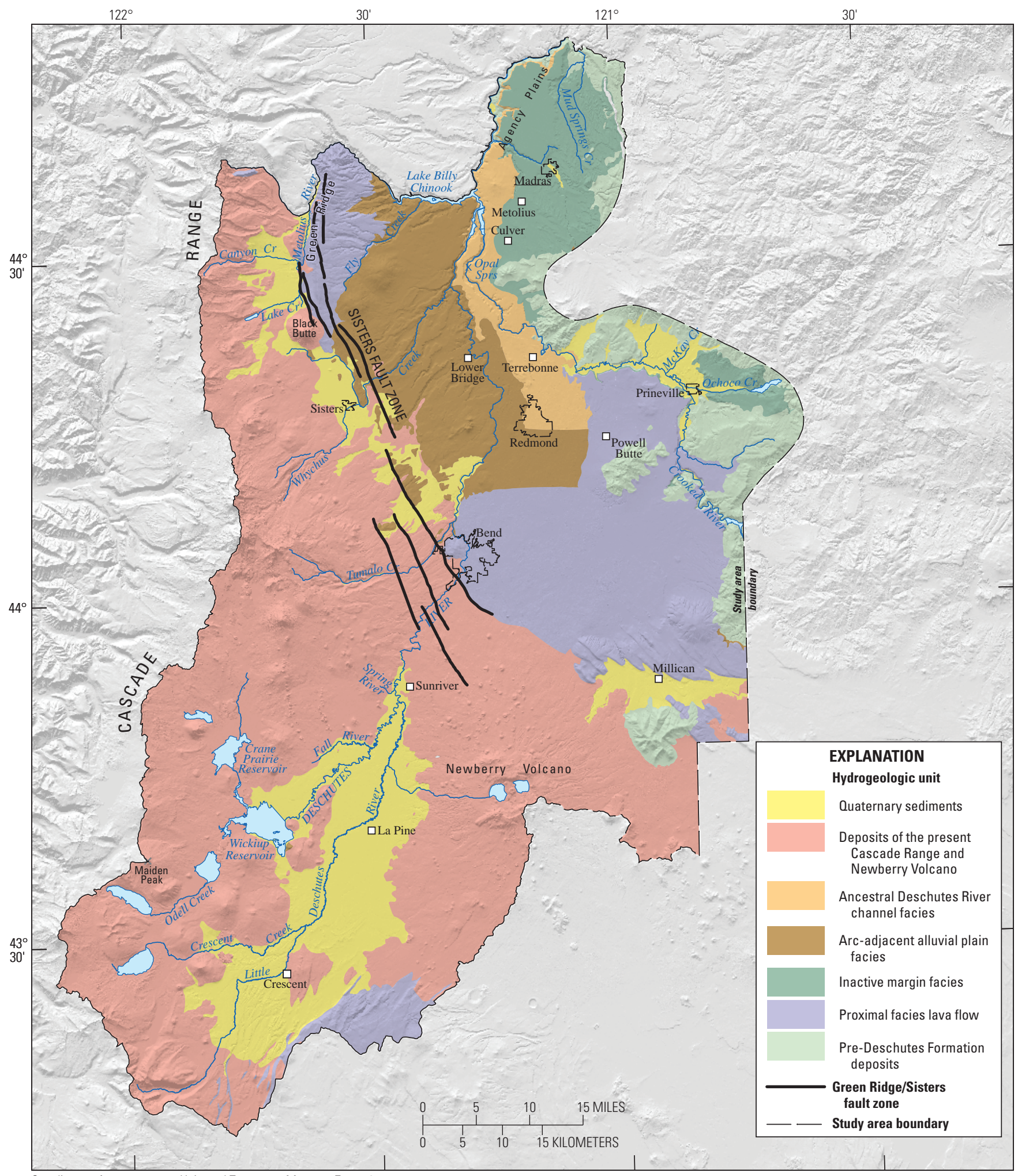

Coordinate reference system: Universal Transverse Mercator Zone 10 North, horizontal datum is North American Datum of 1983.

Figure 3. Hydrogeologic units and major faults in the upper Deschutes Basin, Oregon. 
In the Cascade Range, and beneath Newberry Volcano, the basement is not defined by the top of the John Day Formation, but instead the top of the region where the permeability of younger strata is greatly diminished by hydrothermal alteration and secondary mineralization. The transition from permeable to impermeable rock is indicated in temperature profiles of deep wells, and is identified by a change from isothermal conditions (where convective movement of heat by groundwater flow dominates) to regions that exhibit a linear temperature increase with depth (where conduction dominates). Blackwell (1992) notes that isothermal sections in deep boreholes extend as deep as $1,600 \mathrm{ft}$ at sites in the High Cascades (the Quaternary part of the volcanic arc), but typically extend to depths of less than 1,300 ft. Blackwell and Priest (1996) suggest that groundwater flow at velocities sufficient to affect heat flow is restricted to local regions, except in the $0-1,600 \mathrm{ft}$ depth range in the high Cascade Range. The volume of water moving through low-permeability strata at depths greater than 1,600 ft in the Cascade Range is sufficiently small to be considered negligible compared to the overall groundwater budget, and these low-permeability strata are considered in this study to be the base of the regional groundwater flow system. The younger, permeable near-surface strata in the Cascade Range are included in both the model of Gannett and Lite (2004) and the present model.

The basement deposits are overlain by deposits of the Pliocene Deschutes Formation and age-equivalent strata. Lite and Gannett (2002) subdivide these deposits into four groups based largely on the depositional facies model of Smith (1986), lithologies observed in wells, and borehole geophysics. The Deschutes Formation is largely derived from the ancestral Cascade Range and includes lava flows and domes, ash flows, vent deposits, debris flows, and volcaniclastic alluvial deposits, most of which are permeable. The hydrogeologic units within the Deschutes Formation correspond to the proximal facies (predominantly lava flows), the arc-adjacent alluvial plain facies (largely lava, ash, and debris flows, and volcanic sediment), the ancestral Deschutes River channel facies (primarily coarse sand and gravel deposits and intracanyon lava flows), and, in the northeast part of the study area, an inactive margin facies composed largely of material eroded from the older volcanic uplands to the east. This latter unit has generally lower permeability than the other facies. Most groundwater extraction in the basin is from Deschutes Formation deposits.

The hydrogeologic units of the Deschutes Formation are overlain by a hydrogeologic unit consisting of deposits of the present-day Cascade Range and Newberry Volcano. These deposits consist largely of highly permeable lava flows and domes, vent deposit, pyroclastic deposits, and sedimentary interbeds. These deposits form the surface of most of the upper Deschutes Basin.
The youngest hydrogeologic unit in the study area, the Quaternary sediment, mostly consists of glacial till, glacial outwash, and alluvium. These deposits primarily occur, and are generally saturated, in the La Pine subbasin in the southern part of the study area, in the Cascade Range, and as valley fill deposits along the Crooked River.

In addition to the stratigraphic controls on groundwater flow, there are also effects from geologic structure. The La Pine subbasin, in the southern part of the study area, is underlain by a set of sediment-filled grabens between Newberry Volcano and the Cascade Range crest. They are largely inferred from negative gravity anomalies that suggest 1,800-2,400 ft of structural relief (Couch and Foote, 1985). That inference is consistent with data from deep (555-1,460 ft) water wells in the La Pine area that penetrate large thicknesses of fine-grained sediment (Lite and Gannett, 2002). The presence of this thick sequence of low-permeability strata likely affects groundwater movement and may be partly responsible for the large amount of groundwater discharge at the margins of the Cascade Range in the area.

Another prominent structural feature of the basin is Green Ridge, a 20-mi north-trending fault zone and associated escarpment in the northwestern part of the study area (fig. 3). The feature represents the east margin of an intra-arc graben within the Cascade Range (Allen, 1966; Taylor, 1981; Smith and others, 1987). The region to the west of Green Ridge, which includes the present Cascade Range, has dropped as much as 3,000 ft (Conrey, 1985). Virtually all the groundwater that is recharged in the Metolius subbasin discharges west of the Green Ridge escarpment (Gannett and others, 2001). Over 1,200 cubic feet per second $\left(\mathrm{ft}^{3} / \mathrm{s}\right)$ of groundwater discharges to the Metolius River and its tributary springs and creeks between the headwaters and the confluence with Jefferson Creek, 10 mi downstream (fig. 1). The groundwater discharge is partly a result of topography, but is also likely due in part to the permeability contrast between Deschutes Formation rocks forming the escarpment and flooring the eastern margin of the intra-arc graben and the Pliocene and Pleistocene volcanic and volcaniclastic material filling the graben. Another explanation is that the fault zone and associated dikes form a boundary to horizontal groundwater flow. It is likely that a combination of these mechanisms is responsible.

Groundwater flow is also affected by the Sisters fault zone (fig. 3), which trends about $37 \mathrm{mi}$ north-northwest from the north flank of Newberry Volcano to the vicinity of Black Butte, where it merges with the southern part of Green Ridge fault zone. The Sisters fault zone comprises about 50 mapped faults, one of which, the Tumalo fault, is continuous for about $30 \mathrm{mi}$ (Sherrod and others, 2004). Movement along the Tumalo fault was chiefly dip slip. As much as $180-200 \mathrm{ft}$ of dip separation has occurred in places. Quaternary lava 
flows younger than 0.78 million years exhibit escarpments of 20-30 ft (Sherrod and others, 2004). The influence of the Sisters fault zone on regional groundwater flow is spatially variable and not always clear. The trace of the fault zone is coincident with the eastern edge of a steep precipitation (and recharge) gradient. Differentiating the effects of the recharge gradient and the fault zone is difficult. There are areas, such as in the vicinity of McKinney Butte near the town of Sisters, where groundwater-level data from wells indicate the fault impedes lateral groundwater flow.

The westernmost fault strands of the Sisters fault zone that exhibit down-to-the-west displacement (notably the Tumalo fault) were partial barriers to streams flowing eastward from the Cascade Range and, thus, formed depositional centers for Pleistocene volcanic and glacial outwash deposits. The permeability contrast between the Pleistocene deposits and the upper Miocene to Pliocene Deschutes Formation strata has formed several shallow aquifers, the most extensive of which is in the glacial outwash in the vicinity of Sisters. The geologic framework summarized here provided the basis for the 2004 regional groundwater model by Gannett and Lite (2004) and is largely retained in the present model.

\section{Hydraulic Characteristics}

The hydraulic characteristics of hydrogeologic units in the upper Deschutes Basin as determined from aquifer testing, well-yield analysis, and model analysis are discussed at length by Gannett and others (2001) and Gannett and Lite (2004). In their analysis, they evaluated aquifer test data from the basin, data from yield tests on water well logs, and information in the literature pertinent to the basin and nearby areas.

\section{Hydraulic Conductivity}

Hydraulic conductivity estimates for the basin are derived from transmissivity values from aquifer tests and permeability estimates from modeling studies. Transmissivity values from aquifer tests summarized by Gannett and others (2001) range from 180 to 300,000 feet squared per day $\left(\mathrm{ft}^{2} / \mathrm{d}\right)$, equating to hydraulic conductivity values of about 9-2,300 feet per day $(\mathrm{ft} / \mathrm{d})$. The highest values occurred in the ancestral Deschutes River channel deposits near Redmond.

Analysis of specific capacity data from 959 well-yield tests gave median transmissivity values for most Deschutes Formation wells ranging from 1,900 to $2,300 \mathrm{ft}^{2} / \mathrm{d}$ depending on location. Wells in the inactive margin facies of the Deschutes Formation and in alluvial deposits in the La Pine subbasin had median transmissivity values of about 800 and $900 \mathrm{ft}^{2} / \mathrm{d}$ respectively (Gannett and others, 2001).
There are very few direct measurements of hydraulic conductivity in the Cascade Range, and most knowledge of the large-scale permeability structure there is inferred from analysis of geothermal gradients in exploration wells and heat-flow studies. In simulating groundwater flow and heat transport in the Cascade Range, Ingebritsen and others (1992) estimated the permeability of rocks younger than $2.3 \mathrm{Ma}$ (mega annum, or million years before present) to be about $10^{-13} \mathrm{ft}^{2}$, which is equivalent to a hydraulic conductivity of about $0.018 \mathrm{ft} / \mathrm{d}$ assuming a water temperature of $5^{\circ} \mathrm{C}$. Higher near-surface permeability, on the order of $10^{-13}$ to $10^{-11} \mathrm{ft}^{2}$ (equating to a hydraulic conductivity of about $0.018-1.8 \mathrm{ft} / \mathrm{d}$ ), was required in their simulation to match groundwater recharge estimates. Higher near-surface permeabilities are also suggested by well-test data. A specific-capacity test of a well near Mount Bachelor (18S/09E-20BDA) yielded a hydraulicconductivity estimate of $9 \mathrm{ft} / \mathrm{d}$ (Gannett and others, 2001).

Mathematical modeling of groundwater discharge to spring-fed streams in the Cascade Range by Manga (1996, 1997) yielded permeability values for near-surface rocks less than about 2.0 Ma of about $10^{-10} \mathrm{ft}^{2}$, which equates to a hydraulic conductivity of about $18 \mathrm{ft} / \mathrm{d}$ assuming a water temperature of $5{ }^{\circ} \mathrm{C}$. This estimate is an order of magnitude larger than the upper value of Ingebritsen and others (1992) for near-surface rocks, where most groundwater flow occurs. The permeability estimates of Manga $(1996,1997)$ and Ingebritsen and others (1992) are considered to be a reasonable range of values for the younger, near-surface strata in the Cascade Range.

Calibrated hydraulic conductivities from the groundwater model of Gannett and Lite (2004) range from about 0.6 to $984 \mathrm{ft} / \mathrm{d}$, with most zones in the $10-300 \mathrm{ft} / \mathrm{d}$ range. These are all consistent with the independently derived values. The lowest calibrated value was associated with the central part of Newberry Volcano and the largest was for the part of the model representing the ancestral Deschutes River Deposits.

\section{Vertical Anisotropy}

Values of vertical anisotropy (the ratio of horizontal to vertical hydraulic conductivity) vary widely with geologic settings, although vertical hydraulic conductivity is almost always less than horizontal. Anderson and Woessner (1992) state that vertical anisotropy commonly ranges from 1 to 1,000 . Studies in other volcanic terranes in the Pacific Northwest, however, suggest vertical anisotropy values can exceed 100,000 (Ely and others, 2014). Very large vertical hydraulic head gradients occur in places in the upper Deschutes Basin, suggesting that large vertical anisotropy occurs at least locally. Calibrated values in the 2004 model 
ranged from 1,000 to 42,200 (Gannett and Lite, 2004). Morgan and others (2007) found a vertical anisotropy value of 100 worked well for the near-surface fluvial deposits in the La Pine subbasin in transport models.

\section{Storage Coefficients}

Aquifer tests in the basin indicated a range of storage coefficient values suggesting both confined and unconfined conditions and are summarized by Gannett and Lite (2004). A well in Madras, which produces from a confined sand and gravel aquifer, yielded a storage coefficient of $10^{-4}$. A well in Redmond producing from both lava and interbedded sand and gravel, yielded storage coefficient values ranging from $5 \times 10^{-2}$ to $6 \times 10^{-2}$. Another well, producing from sand and gravel, yielded a storage coefficient of 0.1. The 2004 groundwater model had calibrated storage coefficient values ranging from $4 \times 10^{-6}$ to 0.3 , although most values are in the range of $10^{-4}$ to $10^{-2}$.

\section{Groundwater Flow}

The groundwater hydrology of the upper Deschutes Basin is described in detail by Gannett and others (2001, 2003), building on field observations and interpretations of Russell (1905), Stearns (1931), and Sceva (1960, 1968). Regional groundwater flow in the upper Deschutes Basin is primarily controlled by the distribution of recharge, topography, geology, and location and elevation of streams to which groundwater discharges.

Groundwater discharge is primarily to streams, with the basin-wide total averaging about 4,300 $\mathrm{ft}^{3} / \mathrm{s}$ (Gannett and others, 2003). Groundwater pumping by wells is small in comparison. As of 2008, approximately 55,000 acre-feet per year (acre-ft/yr; a mean annual rate of about $76 \mathrm{ft}^{3} / \mathrm{s}$ ) was pumped for municipal and agricultural use.

\section{Regional Head Distribution}

In this report, the term head elevation, or head, is used to describe the potential energy in an aquifer which results chiefly from elevation of the aquifer and the internal pressure. The term Groundwater-level elevation is generally used herein to refer to the measurements of head obtained from wells.

Regional groundwater movement is from the principal recharge areas in the Cascade Range and Newberry Volcano toward discharge areas along the margin of the Cascade Range and near the confluence of the Deschutes, Crooked, and Metolius Rivers (fig. 4).
At the regional scale, the distribution of recharge mimics that of precipitation. The annual precipitation rate shows considerable geographic variation throughout the upper Deschutes Basin (fig. 2). The Cascade Range, which constitutes the western boundary of the basin, locally receives in excess of $125 \mathrm{in} / \mathrm{yr}$, mostly as snow. The young Quaternary volcanic deposits and thin soils in the Cascade Range allow rapid infiltration of much of the rain and snowmelt, making the Cascades the locus of groundwater recharge for the basin. Gannett and others (2001) and Manga (1997) estimate that as much as 70 percent of the annual precipitation in the Cascade Range becomes recharge. In the central part of the study area, in contrast, precipitation is commonly less than $10 \mathrm{in} / \mathrm{yr}$, providing little or no groundwater recharge.

Although precipitation provides relatively little groundwater recharge in the low-elevation areas in the central part of the basin, leaking irrigation canals are a significant local source of recharge. Estimates of the total mean annual canal loss rate in the mid-1990s ranged from 490 to $520 \mathrm{ft}^{3} / \mathrm{s}$ (Gannett and others, 2001; this study). Piping efforts throughout the area in the past two decades have reduced the mean annual canal loss rate by about $100 \mathrm{ft}^{3} / \mathrm{s}$.

The distribution of recharge, and associated downward flow, locally results in large downward vertical head gradients. Most knowledge of downward flow and vertical head gradients in the Cascade Range, where most recharge occurs, comes from geothermal exploration drilling. For example, data collected during drilling of a 4,006 ft geothermal well in the Cascade Range by Robison and others (1981) indicate vertical gradients ranging from 0.3 to 0.6 . Similar large downward gradients in the areas of substantial canal leakage are reported by Gannett and others (2001).

\section{Groundwater Movement to and from Streams}

A stream reach to which groundwater discharges is referred to as gaining. Conversely, a stream reach that loses water through leakage to underlying aquifers is referred to as losing. Gaining and losing stream reaches in the upper Deschutes Basin mapped by Gannett and others (2001) are shown in figure 5. Roughly half of the groundwater recharged in the Cascade Range discharges to spring-fed streams at lower elevations in the range and along margins of adjacent lowlands. The remaining groundwater continues in the subsurface toward the central part of the basin, where most of it discharges to the Deschutes, Crooked, and Metolius Rivers in the vicinity of their confluence (fig. 5). It should be noted that some of the estimated gains and losses in figure 5 are from single seepage runs and represent a snapshot in time. All the gains and losses shown on figure 5 vary to some degree with time. 


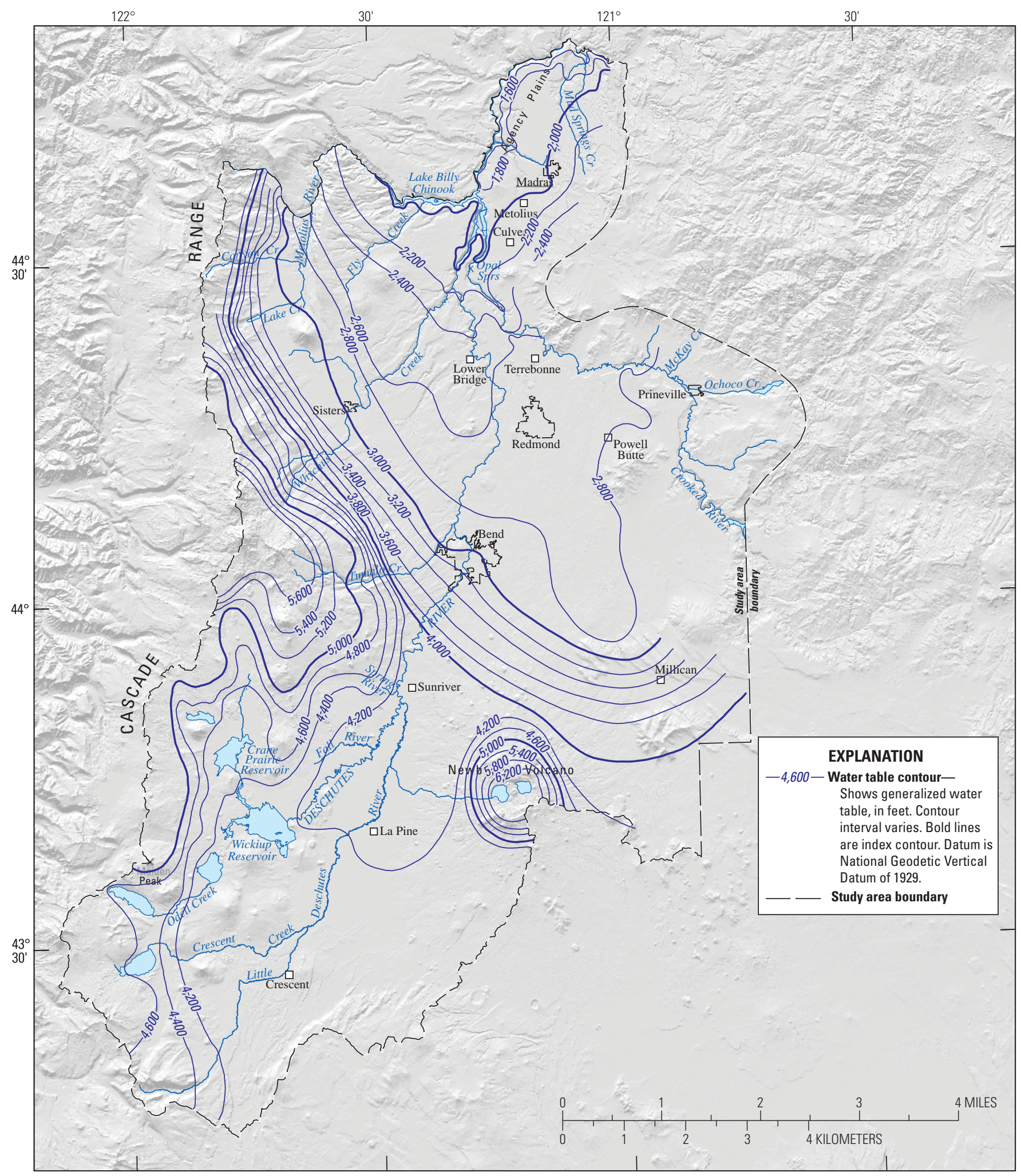

Coordinate reference system: Universal Transverse Mercator Zone 10

North, horizontal datum is North American Datum of 1983.

Figure 4. Generalized water-table elevation in the upper Deschutes Basin, Oregon. Data from Gannett and others, 2001. 


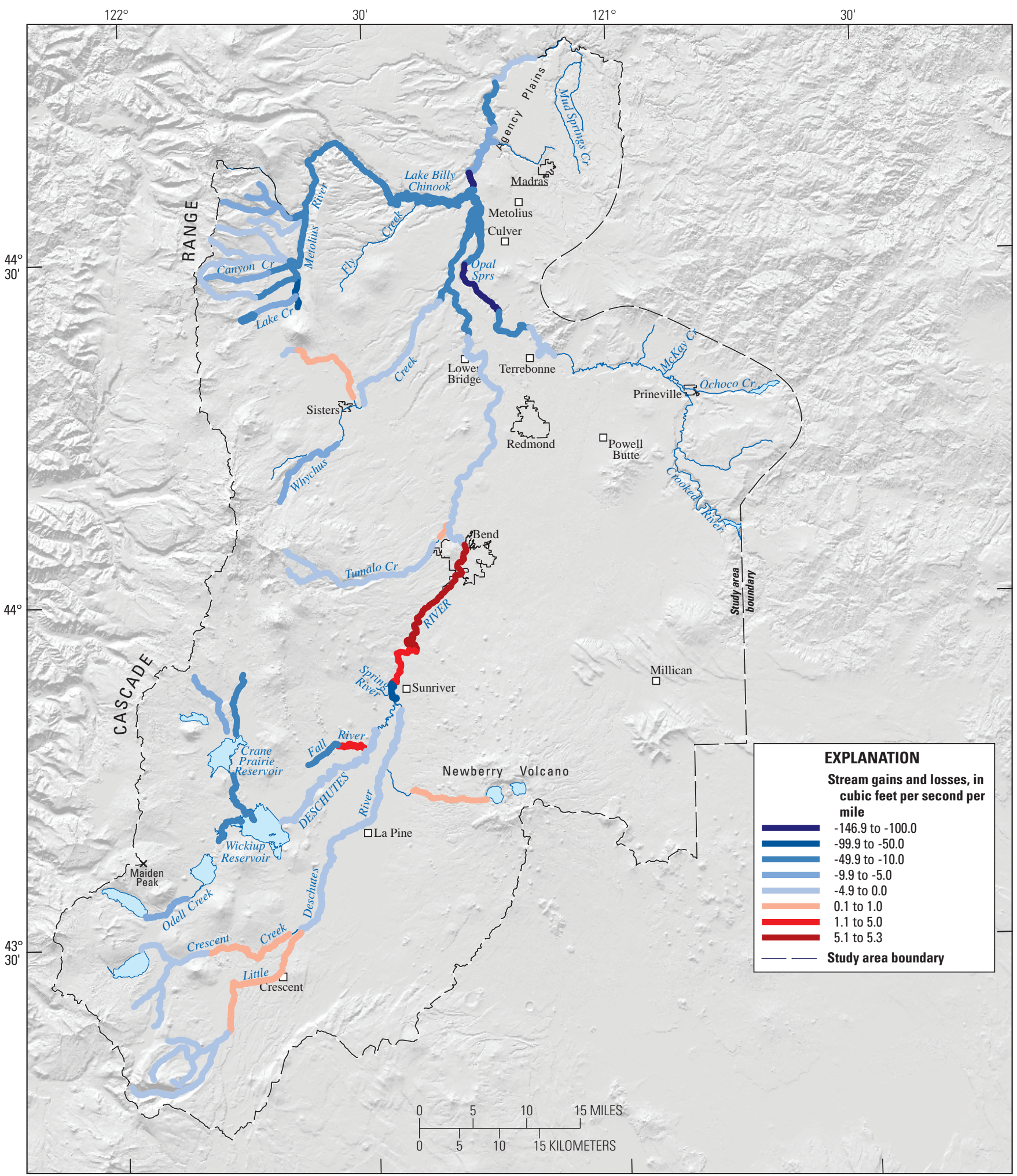

Coordinate reference system: Universal Transverse Mercator Zone 10

North, horizontal datum is North American Datum of 1983.

Figure 5. Distribution of stream gains due to groundwater discharge and stream losses due to seepage to underlying aquifers, upper Deschutes Basin, Oregon. Negative values indicate groundwater discharge to streams (gaining reaches) and positive values indicate seepage from streams to the groundwater system (losing reaches). Data from Gannett and others, 2001. 
The principal groundwater fed streams along the topographic margin of the Cascade Range include the upper Deschutes River and its tributaries upstream of Wickiup Reservoir, Fall and Spring Rivers farther downstream, and the upper Metolius River and its tributaries. Combined groundwater discharge along the margin of the Cascade Range is estimated to average about $2,600 \mathrm{ft}^{3} / \mathrm{s}$, which is roughly one-half the total groundwater discharge of the upper Deschutes Basin (Gannett and others, 2001).

Stream gains and losses along the Deschutes and Little Deschutes Rivers in the La Pine subbasin east of the Cascade Range are small, indicating relatively little net exchange between groundwater and surface water. North of Sunriver, however, the northward slope of the water table is larger than the slope of the land surface, so depths to groundwater generally increase northward toward Bend (fig. 4). In this same reach, however, water is diverted from the Deschutes River into irrigation canals. The combination of leakage from canals, and perhaps from the river itself, supports local shallow, possibly perched, saturated zones that leak water back to the river. Data from several streamgages operated along the Deschutes River between Benham Falls and Bend from 1944 to 1953 (Oregon Water Resources Department, 1965) show that this reach contains both losing and gaining segments. The net loss between Benham Falls and Bend averaged about $90 \mathrm{ft}^{3} / \mathrm{s}$ based on comparison of streamgages at Benham Falls and downstream of Bend between 1945 and 1995.

The Deschutes and Crooked Rivers have incised canyons in the northern part of the study area. The canyons become increasingly deep northward toward Lake Billy Chinook, reaching depths of several hundred feet below the surrounding terrain. About 10-15 mi upstream of their confluence, the canyons of the Deschutes and Crooked Rivers are of sufficient depth to intersect the regional water table, and both streams gain flow from groundwater discharge. Streamflow measurements show that the Deschutes River and lower Whychus Creek combined gain of about $400 \mathrm{ft}^{3} / \mathrm{s}$ from groundwater discharge in this area prior to entering Lake Billy Chinook, and the lower Crooked River gains about 1,100 ft $\mathrm{ft}^{3} / \mathrm{s}$ before entering the lake. Groundwater discharge to Lake Billy Chinook is roughly $420 \mathrm{ft}^{3} / \mathrm{s}$ (Gannett and others, 2001). The total groundwater discharge in the confluence area is approximately 2,300 ft $3 / \mathrm{s}$. This groundwater discharge, along with the 1,200-1,400 ft $3 / \mathrm{s}$ flow of the Metolius River (which is predominantly groundwater discharge), makes up virtually all the flow of the Deschutes River at Madras during the summer and early autumn.

Geologic factors are the primary cause of the large groundwater discharge in the area near the confluence of the Deschutes, Crooked, and Metolius Rivers. The permeable Deschutes Formation strata, through which nearly all regional groundwater flows, thins northward as the low permeability
John Day Formation nears the surface. About 10 miles north of Lake Billy Chinook, the Deschutes River has incised completely through the Deschutes Formation down to the low permeability strata of the John Day Formation, marking the northern extent of the permeable regional aquifer system. Most of the regional groundwater in the upper basin discharges to the Deschutes and Crooked Rivers south of this location. There is no appreciable groundwater discharge directly to the Deschutes River downstream of this point, and the gains in streamflow that do occur result primarily from tributary inflow.

\section{Temporal Variations in Head and Discharge}

Groundwater head elevations and groundwater discharge in the Deschutes Basin both fluctuate in response to seasonal pumping and climate patterns, as well as decadal climate cycles and longer-term climate trends. Head elevations in the Cascade Range and groundwater discharge to major springs, which drive the overall basin behavior, fluctuate primarily in response to decadal climate cycles and longer-term climate trends (Gannett and others, 2001). Decadal head fluctuations in the Cascade Range can exceed $20 \mathrm{ft}$. Groundwater discharge varies in response. For example, August mean groundwater discharge to the Deschutes River between Bend and gage near Culver (USGS streamgage 14076500) varied over $100 \mathrm{ft}^{3} / \mathrm{s}$ during the period between 1962 and 1997 due to climate cycles. Groundwater discharge to the Metolius River, based on October mean flows, varied over $400 \mathrm{ft}^{3} / \mathrm{s}$ during the period between 1962 and 1997. Combined, climate-driven groundwater discharge fluctuations could account for variations in late-season monthly mean flows of the Deschutes River at Madras of about 1,000 $\mathrm{ft}^{3} / \mathrm{s}$ (Gannett and others, 2001).

The groundwater system also responds to longer term climate trends. Climate driven reductions in groundwater recharge in recent decades manifest as a decrease in discharge of most spring-fed streams. For example, mean annual discharge of Fall River, an entirely spring-fed stream, decreased from $150 \mathrm{ft}^{3} / \mathrm{s}$ in the $1970 \mathrm{~s}$ to $110 \mathrm{ft}^{3} / \mathrm{s}$ in the 2000s, a decrease of 27 percent (Gannett and Lite, 2013). Decreases in recharge from precipitation and discharge to spring-fed streams in the upper Deschutes Basin are consistent with decreased discharge of groundwater-dominated streams over the past 50 years elsewhere in the Cascade Range described by Mayer and Naman (2011).

Head elevations also fluctuate in response to local stresses such as canal operation, canal piping, and stream-stage variations. The relative contributions of these various stresses in different areas of the basin between 1997 and 2008 were described by Gannett and Lite (2013). 


\section{Simulation Model}

\section{GSFLOW Integrated Model}

Simultaneous simulation of groundwater and surface water was accomplished using GSFLOW, a model that integrates the USGS Precipitation Runoff Modeling System (PRMS) and the USGS three-dimensional modular groundwater flow model MODFLOW. The version of GSFLOW (version 1.2.1) used for this study integrates PRMS (Markstrom and others, 2015) and Newton formulation of the modular groundwater flow model (MODFLOW-NWT; Niswonger and others, 2011).

For calculations, GSFLOW partitions the hydrologic system into three regions (fig. 6): region 1 (which includes most surface processes) includes the plant canopy, snowpack, surface depression storage, and soil zone processes; region 2 (surface-water bodies) includes streams and lakes; and region 3 includes subsurface processes such as water movement and storage in the unsaturated and saturated zones beneath the soil zone. Water moves between regions depending on soil moisture conditions and head relations. Region 1 is simulated by the PRMS part of the model while regions 2 and 3 are handled by MODFLOW. For a thorough description of GSFLOW, including mathematical formulations, see Markstrom and others (2008).
Both PRMS and MODFLOW require that the simulated domain be spatially subdivided. In PRMS, these subdivisions are known as hydrologic response units (HRUs). HRUs correspond to areas of the land surface across which key characteristics (such as precipitation, temperature, slope, aspect, soil, and vegetation) are considered uniform. In MODFLOW, the finite-difference formulation requires that the subsurface be divided into a three-dimensional rectilinear array of cells known as the model grid. As with HRUs in PRMS, the MODFLOW cells correspond to regions where key characteristics such as permeability, storage characteristics, and boundary conditions are considered uniform. To resolve issues with the 2004 model related to the coarse grid spacing (as much as 10,000 ft), the new MODFLOW model uses a uniform grid spacing of $1968.5 \mathrm{ft}$ (600 m) (fig. 7). This dimension represents the balance between maximizing the spatial resolution of the model and keeping the number of active cells within practical computational and data handling limits. Elevations of the grid cells were determined by generalizing a 10-meter digital elevation model (DEM; https:// nationalmap.gov/3DEP/3dep_prodserv.html). A geographic information system (GIS) was then used to develop a rasterized stream network that was then used for both the PRMS and MODFLOW models.

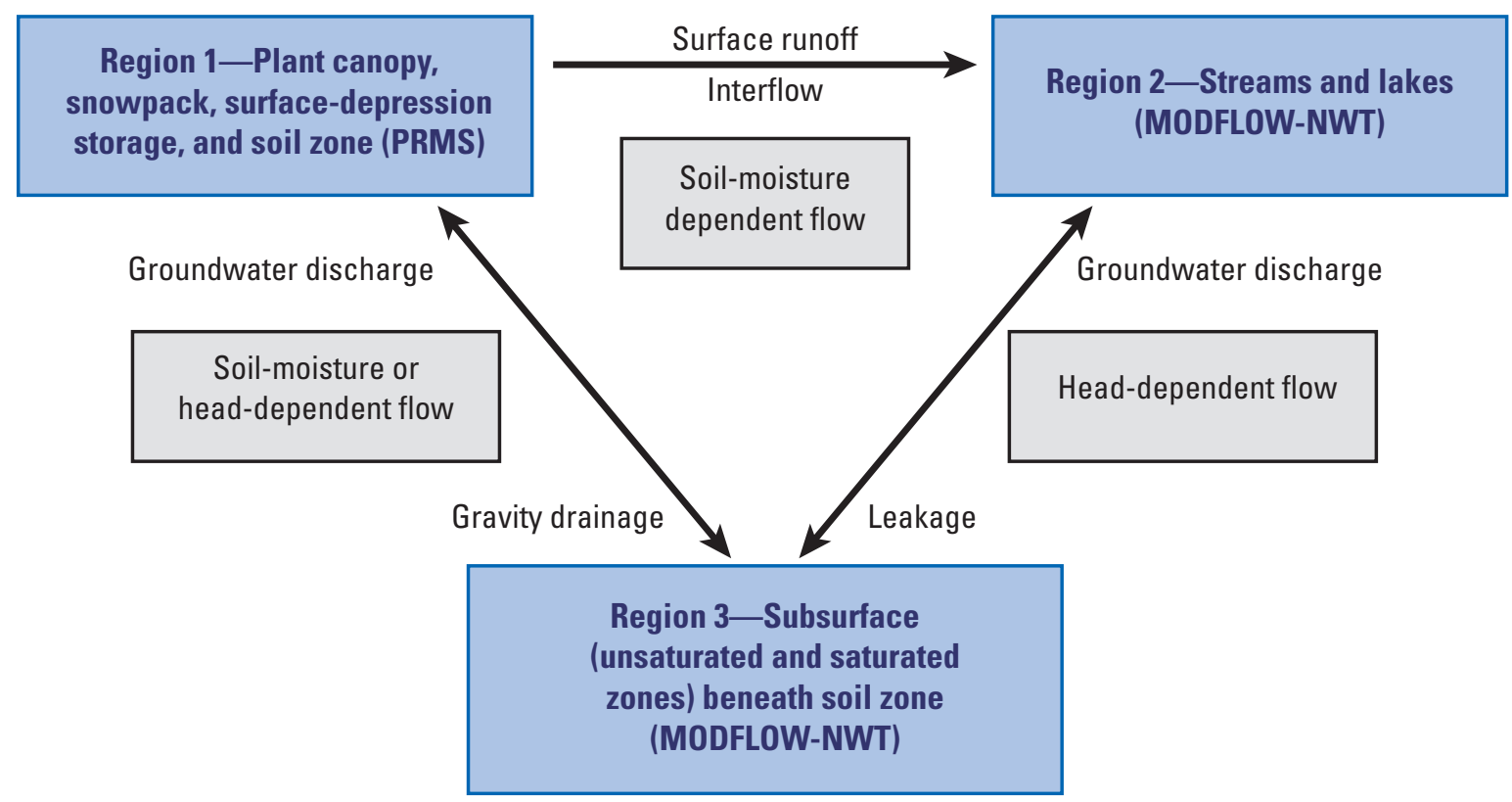

Figure 6. Exchange of flow among the three regions in GSFLOW (from Markstrom and others, 2008). GSFLOW, groundwater and surface-water flow model. 


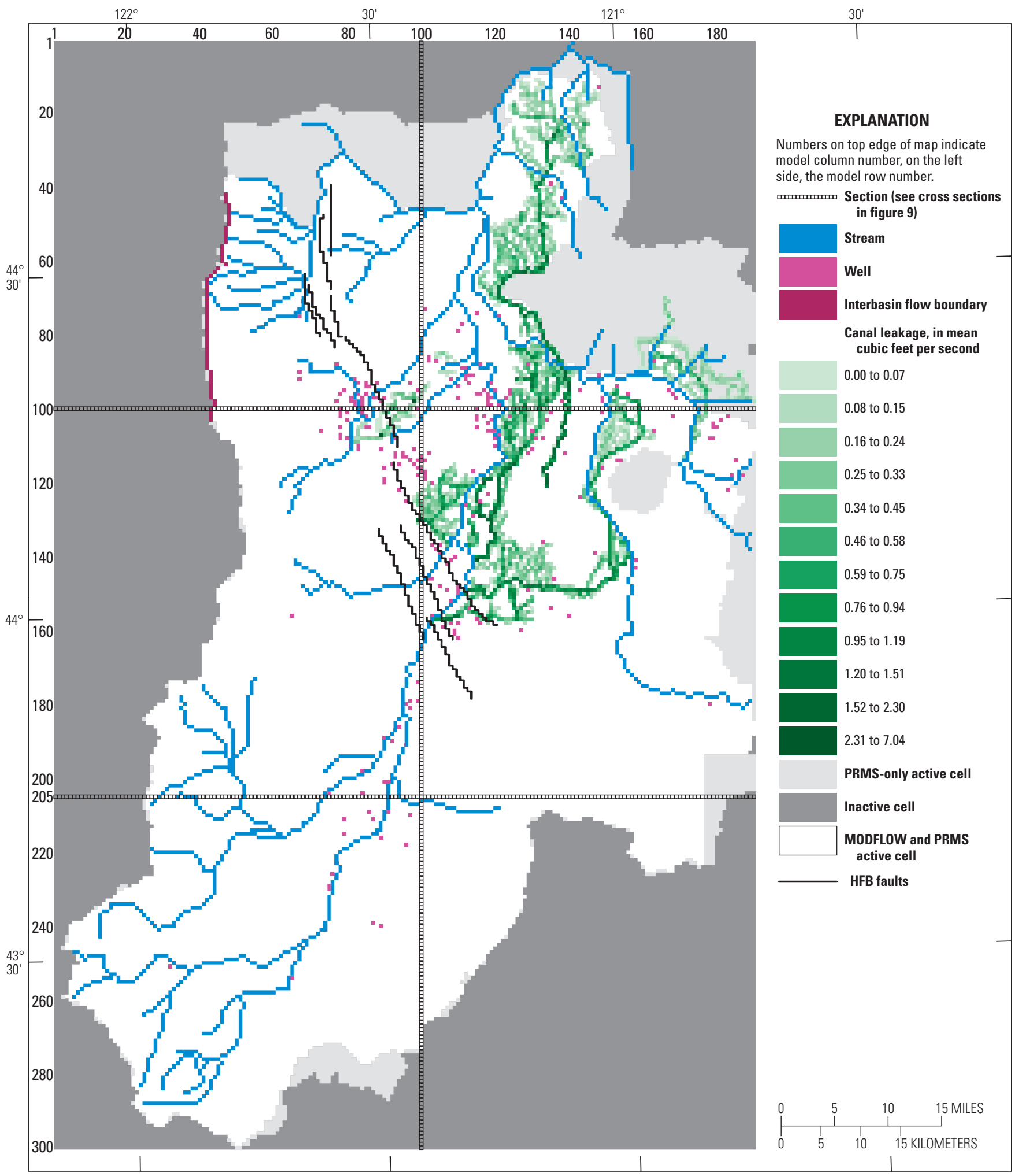

Coordinate reference system: Universal Transverse Mercator Zone

10 North, horizontal datum is North American Datum of 1983.

Figure 7. MODFLOW grid and boundary conditions and active PRMS hydrologic response units for GSFLOW model, upper Deschutes Basin, Oregon. See cross sections in figure 9. GSFLOW, groundwater and surface-water flow model; HFB, horizontal flow barrier; PRMS, precipitation runoff modeling system; MODFLOW, modular groundwater flow model. 
Although PRMS allows any number and shape of HRUs, for this project the PRMS HRUs were delineated as individual grid cells that exactly corresponded to the MODFLOW grid. This allowed the use of the cascade option in GSFLOW that simulates the movement of runoff and shallow subsurface flow from one cell to another along specific paths determined by topography. Without the cascade option, lateral flow is routed directly to the nearest stream without considering the effects of topography and topology. Cascade relations were calculated using the Cascade Routing Tool of Henson and others (2013).

\section{PRMS Model Description}

PRMS (Markstrom and others, 2015) is a physically based, spatially distributed model that takes daily minimum and maximum air temperature and precipitation data and simulates streamflow in a basin. To accomplish this, watershed processes in the model are divided into major components shown schematically in figure 8. Climate inputs consist of precipitation, air temperature, and solar radiation; and surface processes consist of vegetative canopy interception and throughfall, snowpack accumulation, snowmelt, sublimation, evaporation, plant transpiration, soil-zone recharge, and detention storage on impervious surfaces. Movement and storage of water is determined by a daily moisture and energy balance. For example, accumulation, melting, and sublimation of snow are determined by daily temperatures and solar radiation. The model also simulates the daily storage and movement of water between the soil-zone and groundwater reservoirs. Runoff to a stream or lake is the derived combination of surface, subsurface, and groundwater outflows from these three storage reservoirs. A thorough description of PRMS can be found in Markstrom and others (2015).

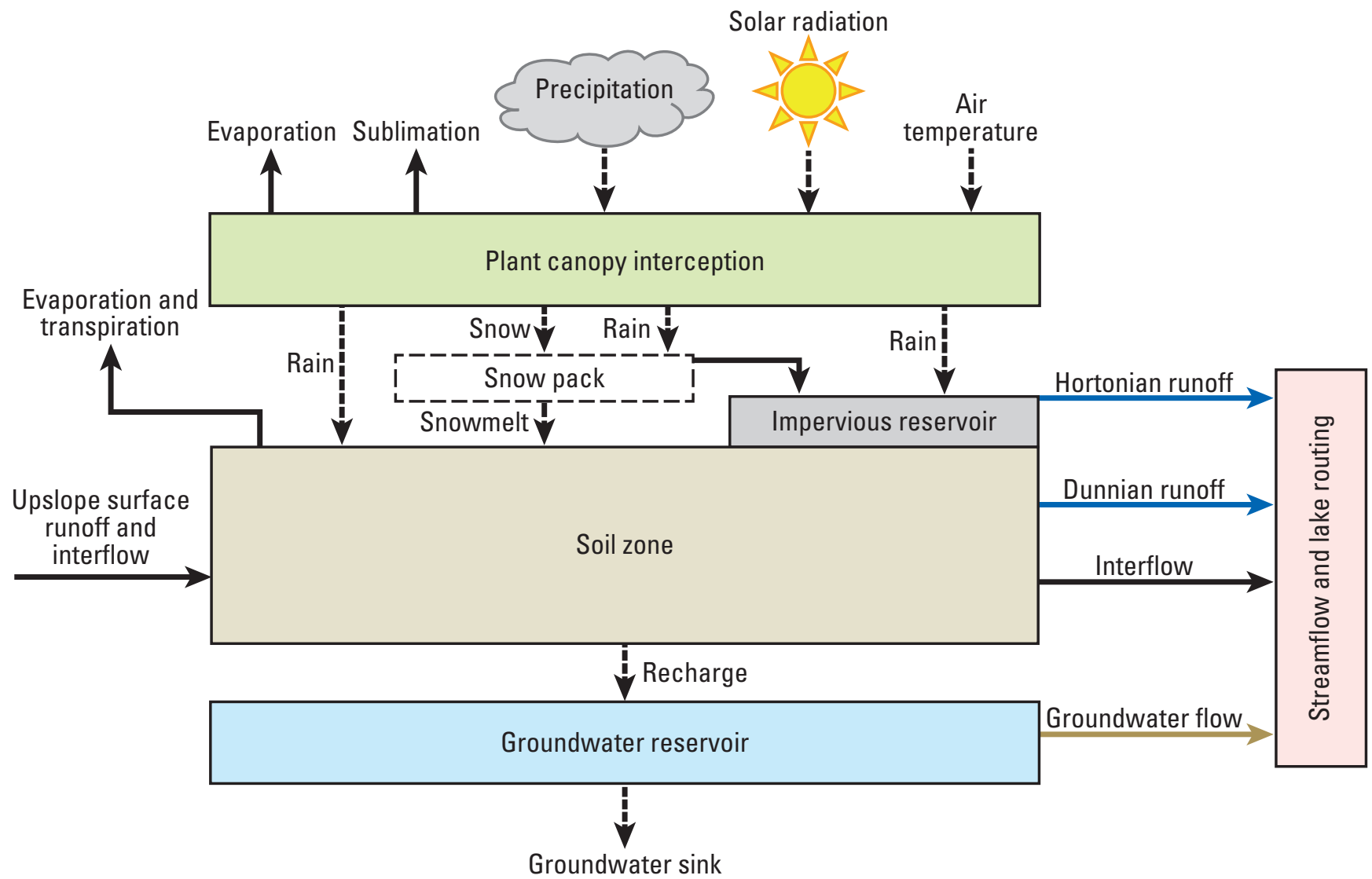

Figure 8. Precipitation Runoff Modeling System climate inputs, watershed components, and flow paths. From Markstrom and others, 2008. 
As a stand-alone model (or when run in "PRMS-only" mode in GSFLOW), groundwater recharge simulated by PRMS is routed to a groundwater reservoir that then discharges to the stream. In GSFLOW, groundwater recharge is routed to the MODFLOW part of the model.

\section{PRMS Model Extent and Spatial Representation}

The PRMS model includes the MODFLOW model domain as well as catchments of some small tributaries to the Metolius, Deschutes, and lower Crooked Rivers in the northern part of the study area not included in the active MODFLOW domain (fig. 7). This aided preliminary calibration of the PRMS model and allows simulation of runoff from those catchments. The PRMS model includes 35,219 active HRUs, 29,930 of which correspond to active MODFLOW cells; and is divided into 22 subbasins corresponding to major streamgages in the basin (table 1).

\section{Land-Surface Characteristics}

Geospatial data layers were used to define land-surface characteristics in the PRMS model. These data layers were derived from the National Land Cover Database (NLCD) 2006 (Fry and others, 2011), State Soil Geographic Database (STATSGO) general soil maps (U.S. Department of Agriculture, 1994), and the National Elevation Dataset (NED) 10-meter digital elevation model (U.S. Geological Survey, 2012). Parameters in the PRMS model used to describe land-surface characteristics based on geospatial data layers are listed in table 2. A full description of PRMS parameters is provided in Markstrom and others (2015).

\section{Land Use}

Sixteen land-use classes from the NLCD; open water, ice/snow, open, low intensity, median intensity, high intensity, barren, deciduous, evergreen, mixed, shrub/ scrub, grass, pasture, crops, wetlands, and herbaceous wetlands) were used to determine appropriate values for HRU dimensioned land-type and vegetative parameters. The plant type parameter (cov_type, $0=$ bare, $1=$ grass, $2=$ shrub, $3=$ trees) value was determined by consolidating the 16 NLCD land-use classes into these 4 classes and then assigning the HRU with the most dominant class code.
Winter and summer cover density parameters (covden_win and covden_sum) and winter and summer interception parameters (wrain_intcp and srain_intcp) were computed by multiplying the fraction of the dominant cov_type class by a weight for that class. Bare ground, grass, shrub, and trees were weighted as $0.05,0.1,0.5$, and 0.9 , respectively. As an example, if an HRU was 96 percent trees, the computed covden_win and covden_sum parameter values would be: $0.96 \times 0.9=0.87$. Because there were no HRUs having a NLCD deciduous tree classification the covden_win and covden_sum parameters were always identical in each HRU. The winter and summer interception HRU parameters (wrain_intcp and srain_intcp) were computed as a function of the cov_type parameter. HRUs that were classified as bare or grass had wrain_intcp and srain_intcp parameter values of zero.

However, HRUs classified as shrub or trees had wrain_intcp and srain_intcp parameter values of 0.05 or 0.1 , respectively. Like the cover density parameters, the winter and summer interception parameters (wrain_intcp and srain_intcp) were also always identical in each HRU because trees in the study area are overwhelmingly conifer. An additional classification from the NLCD included the percent impervious area. These data were used to populate the PRMS hru_percent_imperv parameter for every active HRU.

\section{Soils}

The STATSGO soils geospatial data layers included percent imperviousness, soil composition (sand, clay, or silt), available water capacity fraction, and soil depth data for each HRU. From these data it was possible to compute measured values for the HRU soil parameters. The parameter soil_type was determined as the most dominant soil composition (sand, clay, or silt) in the HRU. The precalibration values for the soil_moist_max and soil_rechr_max parameters were computed as the fraction of available water capacity times the average soil depth. Values for these parameters were then adjusted during calibration.

\section{Topography}

The DEM geospatial data layer derived from the 10-meter NED was used to compute remaining measured HRU dimensioned parameters that included the latitude centroid ( $\left.h r u \_l a t\right)$, mean elevation ( $\left.h r u \_e l e v\right)$, mean aspect ( $\left.h r u \_a s p e c t\right)$, and mean slope ( $\left.h r u \_s l o p e\right)$ of each HRU. 


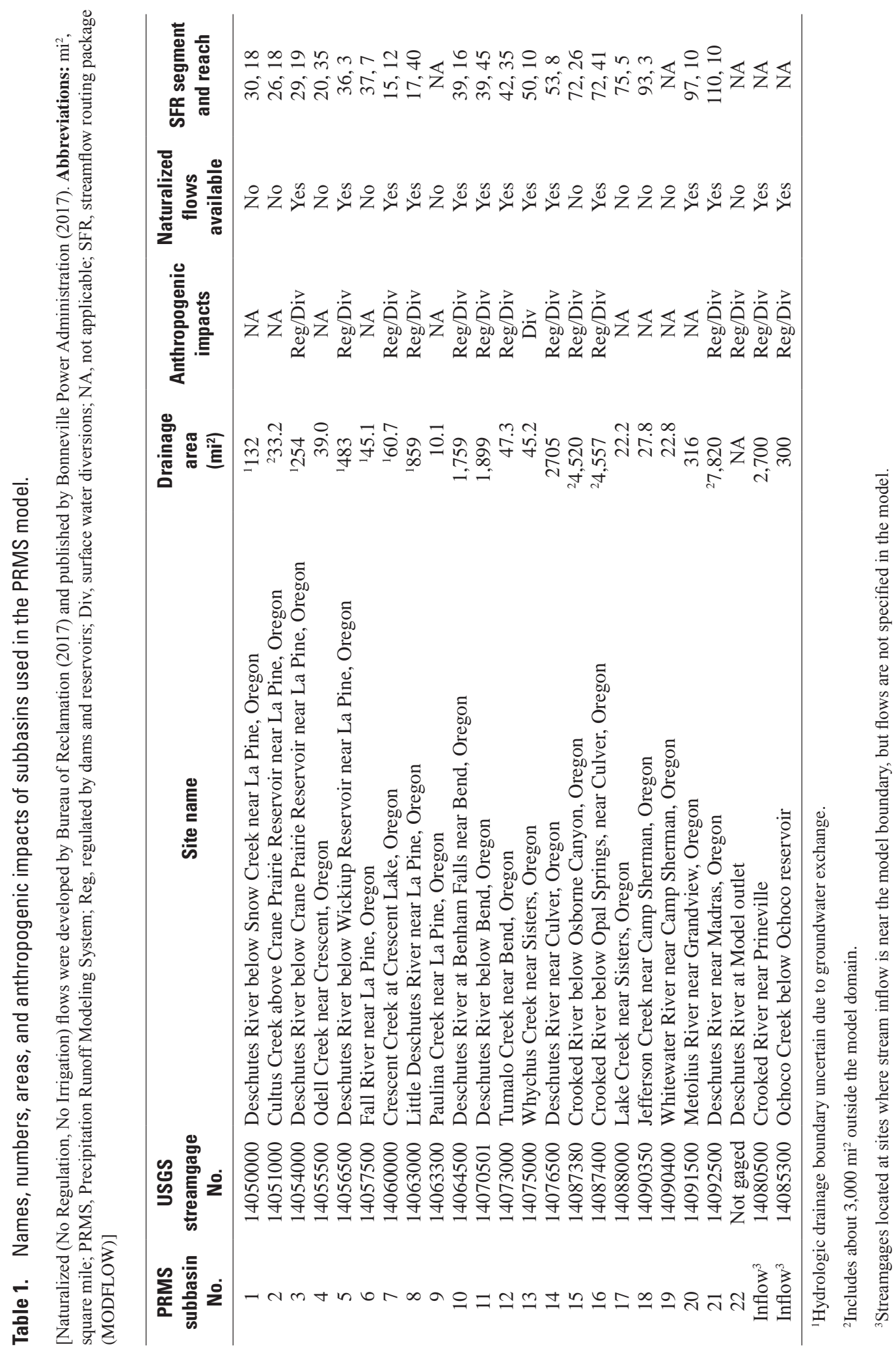


Table 2. Precipitation Runoff Modeling System model parameter values determined from geospatial data or not at default values.

[Source: C, parameters that cannot be estimated from available data and are adjusted during calibration; GC, parameters that are initially computed in GIS and are adjusted, preserving relative spatial variation during calibration; G, parameters measured from GIS data and not adjusted during calibration]

\begin{tabular}{|c|c|c|c|c|}
\hline Dimension & Parameter & Value & Source & \\
\hline one & $\begin{array}{l}\text { basin_solsta } \\
\text { circle_switch } \\
\text { fastcoef_lin } \\
\text { fastcoef_sq } \\
\text { gwflow_coef } \\
\text { gwstor_init } \\
\text { hru_area } \\
\text { imperv_stor_max } \\
\text { melt_force } \\
\text { melt_look } \\
\text { potet_sublim } \\
\text { pref_flow_den } \\
\text { radadj_intcp } \\
\text { sat_threshold } \\
\text { slowcoef_lin } \\
\text { slowcoef_sq } \\
\text { smidx_coef } \\
\text { smidx_exp } \\
\text { snarea_thresh } \\
\text { snowinfil_max } \\
\text { soil_moist_init } \\
\text { soil_rechr_init } \\
\text { soil2gw_max } \\
\text { ssr2gw_rate } \\
\text { tmax_allsnow } \\
\text { transp_beg } \\
\text { transp_end }\end{array}$ & $\begin{array}{c}1.00 \\
0.000 \\
0.005 \\
0.01 \\
0.05 \\
5.0 \\
88.96 \\
0.000 \\
180.00 \\
180.00 \\
0.75 \\
0.0 \\
1.0 \\
15.00 \\
0.01 \\
0.01 \\
0.0001 \\
0.2 \\
40 \\
5.0 \\
1.50 \\
1.45 \\
3.00 \\
1.00 \\
35 \\
4 \\
10\end{array}$ & $\begin{array}{l}\text { C } \\
C \\
C \\
C \\
C \\
C \\
\text { G } \\
\text { C } \\
\text { C } \\
\text { C } \\
\text { C } \\
\text { C } \\
\text { C } \\
\text { C } \\
\text { C } \\
\text { C } \\
\text { C } \\
\text { C } \\
\text { C } \\
\text { C } \\
\text { C } \\
\text { C } \\
\text { C } \\
\text { C } \\
\text { C } \\
\text { C } \\
\text { C }\end{array}$ & \\
\hline Dimension & Parameter & Minimum & Maximum & Source \\
\hline NHRU & $\begin{array}{l}\text { cov_type } \\
\text { covden_sum } \\
\text { covden_win } \\
\text { hru_aspect } \\
\text { hru_elev } \\
\text { hru_lat } \\
\text { hru_psta } \\
\text { hru_slope } \\
\text { hru_subbasin } \\
\text { hru_percent_imperv } \\
\text { hru_tsta } \\
\text { hru_type } \\
\text { jh_coef_hru } \\
\text { soil_moist_max } \\
\text { soil_rechr_max } \\
\text { soil_type } \\
\text { srain_intcp }\end{array}$ & $\begin{array}{c}0 \\
0.00 \\
0.00 \\
0.0 \\
1,394.0 \\
43.21 \\
1 \\
0.00 \\
0 \\
0 \\
1 \\
0 \\
5.00 \\
2.99 \\
1.495 \\
1 \\
0.00\end{array}$ & $\begin{array}{c}3 \\
0.90 \\
0.90 \\
315.0 \\
10,209.0 \\
44.84 \\
587 \\
0.59 \\
22 \\
0.574 \\
587 \\
2 \\
5.00 \\
18.03 \\
9.015 \\
3 \\
0.10\end{array}$ & $\begin{array}{c}\text { G } \\
G \\
G \\
G \\
G \\
G \\
G \\
G \\
G \\
G \\
G \\
G \\
C \\
G C \\
G C \\
G \\
G\end{array}$ \\
\hline
\end{tabular}


Table 2. Precipitation Runoff Modeling System model parameter values determined from geospatial data or not at default values.-Continued

\begin{tabular}{llccc}
\hline \multicolumn{1}{c}{ Dimension } & Parameter & Minimum & Maximum & Source \\
\hline \multirow{2}{*}{ nmonths } & wrain_intcp & 0.00 & 0.10 & $\mathrm{G}$ \\
& cecn_coef & 1.0 & 1.0 & $\mathrm{C}$ \\
& dday_intcp & -30.0 & -10.0 & $\mathrm{C}$ \\
& dday_slope & 0.30 & 0.45 & $\mathrm{C}$ \\
& jh_coef & 0.00380 & 0.00811 & $\mathrm{C}$ \\
nmonths by nhru & tmax_allrain & 43.0 & 43.0 & $\mathrm{C}$ \\
& rain_adj & 0.65 & 1.10 & $\mathrm{C}$ \\
ntemp & snow_adj & 0.65 & 1.10 & $\mathrm{C}$ \\
\hline
\end{tabular}

\section{Climate Input}

\section{Daily Precipitation and Air Temperature}

Daily climate inputs to the PRMS model included precipitation, and minimum and maximum air temperature. Because of the limited availability of meteorological stations at many locations in the study modeling area, a gridded climate station approach was used in this study. Gridded daily precipitation and minimum and maximum air temperature times series data (January 1, 1980, to December 31, 2013) for 587 hypothetical climate stations covering the model domain were downloaded from the USGS Geo Data Portal (GDP) (Blodgett and others, 2011; https://cida.usgs.gov/ gdp/, accessed February 26, 2017). The precipitation and air temperature data were interpolated by the GDP from 1-km $\times$ 1-km Daymet model climate output (Thornton and others, 2016). The 587 hypothetical climate stations were located and spaced every 3 arc-minutes by both latitude and longitude over the modeling area. To download the Daymet time series files it was necessary to upload a geospatial shape file containing 587 point locations of the climate stations which were each buffered with a $0.5 \mathrm{mi}$ radius area. The GDP overlaid the buffered circled areas over the Daymet grid and computed a weighted average of the climate data. Output from the GDP included three sets of 587 columns of daily data for precipitation and minimum and maximum air temperature. This output was reformatted into the PRMS input data file.

The dimensions for the number of precipitation (nrain) and air temperature (ntemp) stations in PRMS were both set to 587. Each HRU was associated with a precipitation and temperature station (using the hru_psta and hru_tsta parameters) based on proximity. The effect of elevation on air temperature differences between an HRU and a corresponding climate station were accounted for within PRMS with minimum (tmin_lapse) and maximum (tmax_lapse) air temperature monthly lapse rates. All the lapse rates were set to the default value of $3^{\circ} \mathrm{F}$ for every $1,000 \mathrm{ft}$ change in elevation. The impact of differences in elevation between an HRU and the corresponding climate station for rain and snow were accounted for in PRMS using the rain_adj and snow snow_adj parameters that have the dimensions of months times the number of HRUs. At the start of the calibration, both parameters were set to their default values of 1.0 for all HRUs and all months.

\section{MODFLOW Model Description}

Movement of water in the unsaturated and saturated zones below the soil zone, and to and from surface-water bodies, is simulated using MODFLOW, the USGS modular groundwater flow modeling system. MODFLOW simulates groundwater flow through porous media in three dimensions using the finite-difference method. A full description of MODFLOW and the underlying governing equations can be found in McDonald and Harbaugh (1988) and Harbaugh (2005). This model uses the Newton formulation of MODFLOW, MODFLOW-NWT (Niswonger and others, 2011). This section describes some of the key elements of the MODFLOW model including the subdivision of the model domain into discrete regions or grid cells (spatial discretization), the subdivisions of time (temporal discretization), the hydraulic characteristics assigned to individual grid cells, and the boundary conditions. 


\section{Spatial Discretization}

The spatial extent of the MODFLOW model corresponds to the entire study area as previously described. This approximately $4,500 \mathrm{mi}^{2}$ area is subdivided into $1968.5 \times 1968.5 \mathrm{ft}(600 \times 600 \mathrm{~m})$ square cells in a rectangular array of 190 north-south columns by 300 east-west rows covering an area of about $71 \times 112 \mathrm{mi}$ (fig. 7). For comparison, the 2004 model, which had the same geographic extent, had cells ranging in size from 2,000 to $10,000 \mathrm{ft}$ on a side in an array of 87 columns and 127 rows.

The model domain is divided vertically into eight layers of varying thickness to represent specific strata, to allow the geometry of hydrogeologic units to vary with depth, and to allow simulation of vertical head gradients and vertical flow (fig. 9 and table 3). Layers 2 through 8 cover the entire model area except where they terminate against impermeable bedrock near the model margins. Layer 1 is used only in specific areas where needed to represent surficial sediments or near-surface volcanic deposits.

Of the 456,000 grid cells that make up the model mesh (300 rows by 190 columns by 8 layers), 195,407 are active, meaning they are within the study area (which is not rectangular) and correspond to regions of permeable geologic materials through which groundwater flows. The groundwater flow equation is solved for the active cells and the remaining "inactive" cells are not included in the simulations.

The top of the uppermost active layer in the model (either layer 1 or 2) corresponds to land surface. The base of layer 2 was set to be approximately $150 \mathrm{ft}$ below the expected top of the saturated zone to help with numerical stability. The remaining layers (3 through 8) each represent one-sixth of the thickness between the base of layer 2 and the top of the underlying impermeable basement. The thickness of layer 1 ranges from 10 to 2,272 ft with a median of $66 \mathrm{ft}$, layer 2 ranges from 11 to $3,842 \mathrm{ft}$ with a median of $564 \mathrm{ft}$, and layers 3 through 8 range from 10 to $274 \mathrm{ft}$ with a median of 170. The thick regions in layers 1 and 2 correspond to local volcanic centers such as large cinder cones that are largely unsaturated. A minimum cell thickness of $10 \mathrm{ft}$ was used to help with numerical stability. The surface elevations of the individual cells in the model grid represent the average elevations of the 10-m digital elevation model (DEM) from which the model grid was generalized.

\section{Temporal Discretization}

In MODFLOW, time is divided into "stress periods" and "time steps." Stress periods are lengths of time over which boundary stresses, such as pumping, are assumed constant. Stress periods are divided into time steps. MODFLOW solves the groundwater flow equation and all the associated heads and flows each time step. The 2004 model used semiannual stress periods (181-184 days long depending on the year), with 5 time steps of increasing length each stress period, ranging from approximately 14 to 71 days. The present GSFLOW model uses monthly stress periods that correspond to monthly pumping estimates. In a stand-alone MODFLOW application, time-step lengths can be variable and are chosen to provide heads and flows at useful intervals, allow reasonable model run times, ensure numerical stability, and minimize budget errors. GSFLOW requires MODFLOW to operate on daily time steps to correspond to the requirements of PRMS. Unlike stand-alone MODFLOW applications where recharge is specified each stress period, GSFLOW routes groundwater recharge from PRMS to MODFLOW each daily time step. As presently configured, the upper Deschutes Basin GSFLOW model is configured to run from January 1, 1980 through December 31, 2013.

\section{Boundary Conditions}

Boundary conditions control the flow of water into and out of the groundwater system in a MODFLOW simulation. MODFLOW boundary conditions for the GSFLOW model are in two categories: specified flow and head-dependent flow. At specified flow boundaries, flow into or out of the model remains fixed during each stress period, independent of the head in the groundwater system. Pumping wells are an example of a typical specified flow boundary. Head-dependent flow boundaries, in contrast, are those across which the rate of flow varies according to the simulated head in the associated model cell. Streams are an example of head-dependent flow boundaries, where the movement of groundwater between the stream and the aquifer depends on the head in the aquifer relative to the stream stage. Boundary conditions are shown in figure 7. 


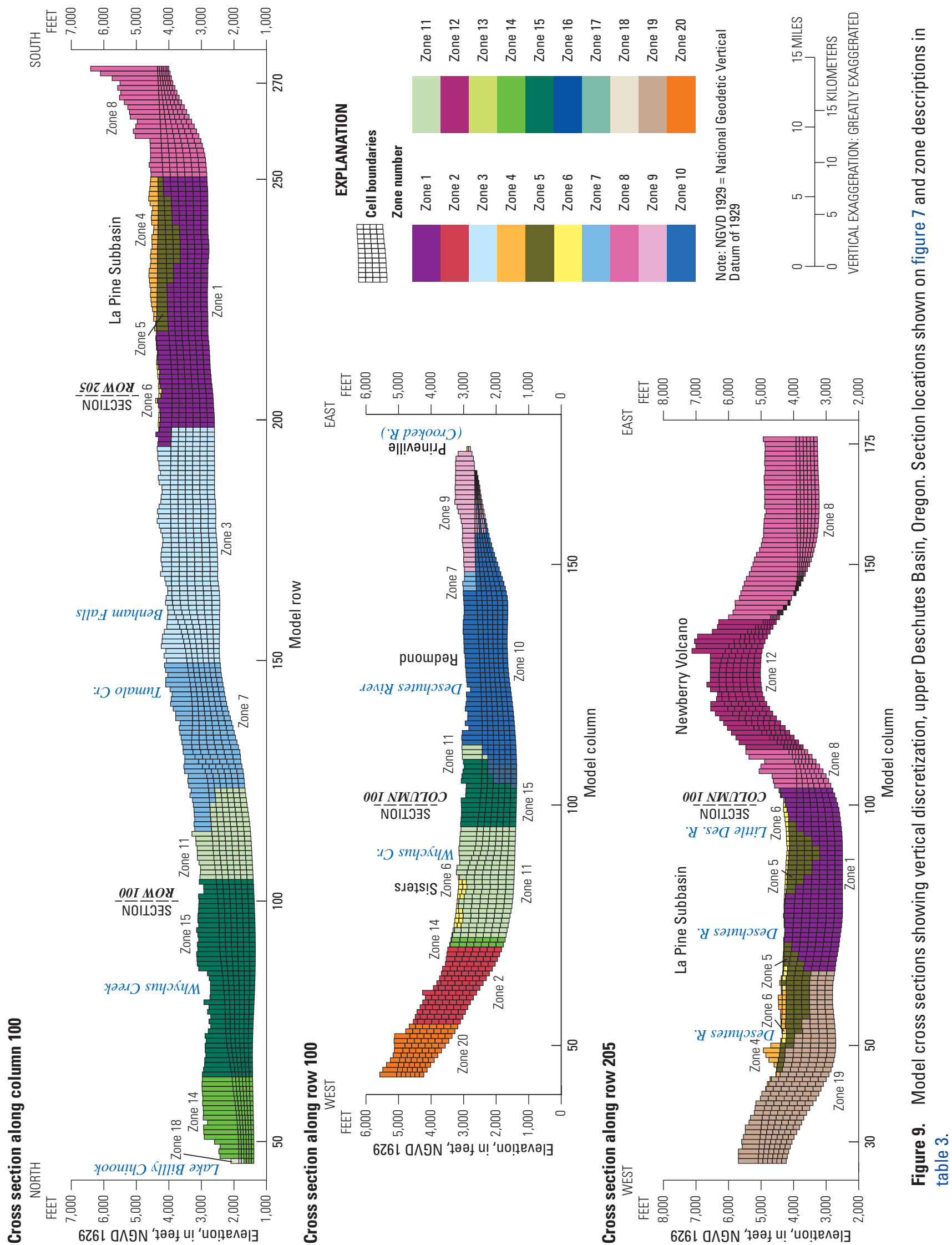


Table 3. Final MODFLOW parameter values and descriptions of MODFLOW zones used in the upper Deschutes Basin, Oregon, GSFLOW model.

[A bbreviations: HFB, horizontal flow barrier package; K, hydraulic conductivity (in feet per second); SS, specific storage (1/foot); SY, specific yield (dimensionless); SFR, streamflow routing package; VANI, vertical anisotropy (dimensionless)]

\begin{tabular}{crlrrrr}
\hline Zone & Layer(s) & Zone Description & K & VANI & SS & SY \\
\hline 1 & $2-8$ & La Pine subbasin, deep volcanic strata & $5.79 \mathrm{E}-5$ & 100 & $2.5 \mathrm{E}-5$ & $1.0 \mathrm{E}-1$ \\
2 & $2-8$ & Central Cascades & $5.00 \mathrm{E}-5$ & 10,000 & $2.5 \mathrm{E}-6$ & $1.0 \mathrm{E}-1$ \\
3 & $2-8$ & Benham Falls area & $1.00 \mathrm{E}-4$ & 10,000 & $2.5 \mathrm{E}-6$ & $1.0 \mathrm{E}-1$ \\
4 & $1-2$ & La Pine subbasin, shallow volcanic strata & $5.72 \mathrm{E}-5$ & 100 & $2.5 \mathrm{E}-6$ & $1.0 \mathrm{E}-1$ \\
5 & $2-7$ & La Pine subbasin, graben-filling sedimentary deposits & $1.16 \mathrm{E}-5$ & 100 & $2.5 \mathrm{E}-6$ & $1.0 \mathrm{E}-1$ \\
6 & $1-2$ & Glacial outwash and alluvium & $1.94 \mathrm{E}-2$ & 1,000 & $2.5 \mathrm{E}-6$ & $1.0 \mathrm{E}-1$ \\
7 & $2-7$ & Bend area & $1.04 \mathrm{E}-3$ & 10,000 & $2.5 \mathrm{E}-6$ & $1.0 \mathrm{E}-1$ \\
8 & $2-8$ & Newberry Volcano flanks & $1.00 \mathrm{E}-4$ & 10,000 & $2.5 \mathrm{E}-6$ & $1.0 \mathrm{E}-1$ \\
9 & $2-8$ & Powell Buttes area, north and east & $4.66 \mathrm{E}-5$ & 1,102 & $2.5 \mathrm{E}-6$ & $1.0 \mathrm{E}-1$ \\
10 & $2-8$ & Redmond area & $6.94 \mathrm{E}-3$ & 10,000 & $2.5 \mathrm{E}-6$ & $1.0 \mathrm{E}-1$ \\
11 & $2-8$ & Sisters area & $2.79 \mathrm{E}-4$ & 1,000 & $2.5 \mathrm{E}-6$ & $1.0 \mathrm{E}-1$ \\
12 & $2-8$ & Newberry Volcano central core & $3.83 \mathrm{E}-6$ & 1,000 & $2.5 \mathrm{E}-6$ & $1.0 \mathrm{E}-1$ \\
13 & $2-8$ & Madras area & $6.73 \mathrm{E}-4$ & 1,000 & $2.5 \mathrm{E}-6$ & $1.0 \mathrm{E}-1$ \\
14 & $2-8$ & Upper Metolius and Green Ridge area & $8.00 \mathrm{E}-4$ & 1,000 & $2.5 \mathrm{E}-6$ & $1.0 \mathrm{E}-1$ \\
15 & $2-8$ & Lower Whychus Creek area & $5.79 \mathrm{E}-4$ & 9,754 & $2.5 \mathrm{E}-6$ & $1.0 \mathrm{E}-1$ \\
16 & $2-8$ & Deschutes and Crooked Rivers confluence area & $6.94 \mathrm{E}-3$ & 3,757 & $2.5 \mathrm{E}-6$ & $1.0 \mathrm{E}-1$ \\
17 & 1 & Davis-Wickiup interlake lava flow & $2.53 \mathrm{E}-2$ & 1,000 & $1.0 \mathrm{E}-1$ & $1.0 \mathrm{E}-1$ \\
18 & $2-8$ & Lake Billy Chinook & $3.34 \mathrm{E}-2$ & 1,000 & $1.0 \mathrm{E}-1$ & $1.0 \mathrm{E}-1$ \\
19 & $2-8$ & Southern Cascades & $4.63 \mathrm{E}-4$ & 8,005 & $2.5 \mathrm{E}-5$ & $1.0 \mathrm{E}-1$ \\
20 & $2-8$ & Northern Cascades & $4.63 \mathrm{E}-4$ & 10,000 & $2.5 \mathrm{E}-5$ & $1.0 \mathrm{E}-1$
\end{tabular}

\section{SFR stream segment}

\section{Description of segment or segments}

Little Deschutes River Drainage to unnamed tributary south of Gilchrist

Little Deschutes River from unnamed tributary south of Gilhrest to Crescent Creek

Crescent Creek Drainage above (and including) Big Marsh Creek

Little Deschutes River Drainage below Crescent Creek, and Crescent Creek below Big Marsh Creek

Odell Creek and Moore Creek

Artificial stream segment between Davis Lake and Wickiup Reservoir

Browns Creek

Charlton Creeek

Tributaries to Crane Prairie Reservoir (except Charlton Creek) and Deschutes River above Wickiup Reservoir

Stream confluences in Wickiup Reservoir

Deschutes River between Wickiup Reservoir and Little Deschutes River confluence

Deschutes River between the Little Deschutes confluence and Tumalo Creek

Tumalo Creek above (and including) Bridge Creek

Tumalo Creek below Bridge Creek

Deschutes River and tributaries between Tumalo Creek and Lower Bridge

Deschutes River and tributaries between Lower Bridge and McKenzie Canyon

Intermittent stream in McKenzie Canyon

Deschutes River McKenzie Canyon to Whychus Creek

Upper Whychus Creek and tributaries

Whychus Creek from gage to Indian Ford Creek

Indian Ford Creek

Whychus Creek from Indian Ford Creek to the Deschutes River confluence

Deschutes River from Whychus Creek to Crooked River confluence
Median

streambed

K

1.00E-3

$1.00 \mathrm{E}-10$

2.24E-5

1.00E-10

2.24E-5

$1.00 \mathrm{E}-8$

$1.00 \mathrm{E}-3$

$1.00 \mathrm{E}-4$

$1.00 \mathrm{E}-3$

$1.00 \mathrm{E}-8$

$1.00 \mathrm{E}-3$

1.32E-4

$1.00 \mathrm{E}-3$

$1.00 \mathrm{E}-6$

$1.00 \mathrm{E}-10$

6.00E-6

$1.00 \mathrm{E}-10$

6.00E-6

7.53E-4

7.53E-7

7.53E-4

$1.00 \mathrm{E}-10$

6.00E-6 
Table 3. Final MODFLOW parameter values and descriptions of MODFLOW zones used in the upper Deschutes Basin, Oregon, GSFLOW model.-Continued

\begin{tabular}{|c|c|c|c|}
\hline $\begin{array}{l}\text { SFR stream } \\
\text { segment }\end{array}$ & & Description of segment or segments & $\begin{array}{c}\text { Median } \\
\text { streambed } \\
\text { K }\end{array}$ \\
\hline 72 & & Crooked River from Lone Pine Creek to the Deschutes River confluence & $1.00 \mathrm{E}-3$ \\
\hline 73 & & Deschutes River between the Crooked and Metolius River confluences & $6.00 \mathrm{E}-6$ \\
\hline 74-99 & & Metolius River and tributaries above Fly Creek & $1.88 \mathrm{E}-4$ \\
\hline $107-118$ & & Deschutes River and tributaries below Metolius River confluence & $1.86 \mathrm{E}-5$ \\
\hline $\begin{array}{l}\text { HFB fault } \\
\text { segment }\end{array}$ & Layers & Description of fault segments & Fault K \\
\hline North & $1-8$ & Green Ridge/Black Butte area & $1.38 \mathrm{E}-7$ \\
\hline
\end{tabular}

\section{Specified Flow Boundaries}

There are four types of specified flow boundaries in the model: no-flow boundaries, interbasin-flow boundaries, pumping wells, and recharge from leaking canals. No-flow boundaries correspond to the edges and base of the model where groundwater flow is assumed negligible (fig. 7). No-flow boundaries occur where the model boundary coincides with surface drainage divides, including most of the crest of the Cascade. The contact between the Deschutes Formation (and age-equivalent rocks) and the John Day and Clarno Formations and other low-permeability strata is also a no-flow boundary.

\section{Interbasin Flow}

Interbasin flow across the Cascade Range crest is specified in the uppermost Metolius River drainage (fig. 7). While developing the earlier model, Gannett and Lite (2004) estimated that groundwater discharge to the upper Metolius River exceeded calculated recharge in the associated drainage area by about $800 \mathrm{ft}^{3} / \mathrm{s}$, and discussed reasons why the surface drainage divide may not correspond precisely to the groundwater divide. They specified an $800 \mathrm{ft}^{3} / \mathrm{s}$ flow across the model boundary corresponding the Cascade Range crest in that area. During calibration of the present model, it was determined that a specified flow of $994 \mathrm{ft}^{3} / \mathrm{s}$ improved the model fit. This flow is divided between cells in layers 2 through 5 along the western edge of the active model domain corresponding to rows 42 through 103 (fig. 7). This flow does not vary with time in the simulations.

\section{Canal Leakage}

Leakage from irrigation canals is a significant source of groundwater recharge in some areas and is simulated as a specified flow boundary. There are approximately $720 \mathrm{mi}$ of canals and laterals that carry water diverted from the Deschutes and Crooked Rivers to about 120,000 acres of irrigated lands in the basin. Many of the canals are constructed in young, highly fractured basaltic lava, and consequently leak large quantities of water. Most of the leakage percolates to the water table and is a significant source of groundwater recharge in the irrigated parts of the basin.

Gannett and others (2001) estimated canal leakage during the mid-1990s using several sources of information, including: (1) diversions into canals measured at gaging stations, (2) estimates of irrigated acreage and crop-water applications from satellite imagery, (3) estimates of canal leakage rates from ponding experiments and surveys of canal-bottom geology by the Bureau of Reclamation (Reclamation; Bureau of Reclamation, 1991a, 1991b), and (4) estimates of irrigation efficiency by Reclamation (Bureau of Reclamation, 1993). 
The canal leakage volume was calculated as the residual of the volume of water diverted into canals minus the volume of water delivered to farms. Methods used to estimate on-farm deliveries are described in detail by Gannett and others (2001). The areal distribution of canal leakage in the main canals and laterals (fig. 7) was estimated on the basis of information on canal-bottom geology and canal geometry.

Canal leakage in the upper Deschutes Basin has diminished since the mid-1990s due to conservation efforts, chiefly piping of unlined canals. Gannett and Lite (2013) used information on reduction in canal leakage due to piping from the mid-1990s through 2008 to simulate the effects of canal piping on the groundwater system using the 2004 model. Loss rates to individual cells were reduced with time as piping efforts for associated canal segments were completed. Their data were updated through 2013 using OWRD records and remapped to the GSFLOW model grid. Canal leakage in the mid-1990s is estimated to have been about 379,000 acre-ft/yr, a mean annual rate of about $520 \mathrm{ft}^{3} / \mathrm{s}$. The 2013 leakage volume is estimated to be 72,500 acre-ft/yr $\left(100 \mathrm{ft}^{3} / \mathrm{s}\right)$ less than in 1994, a reduction of about 19 percent. The annual leakage volumes were parsed into monthly volumes based on average monthly diversion rates by the major irrigation districts. Annual rates were not adjusted for climatic variations.

Canal leakage was specified for the associated model grid location each stress period using the MODFLOW WEL package. The canal loss was added to layer 2 , because it is the uppermost active layer in most of the affected area. Groundwater levels in wells have been shown to rapidly respond to canal operation, indicating rapid movement of water through the unsaturated fractured bedrock (see Gannett and others, 2001, fig. 34).

Wells

Pumping by wells is also a specified flow boundary. As of 2013, pumping for public water supply and irrigation use totaled about 29,585 and 25,535 acre-ft/yr (41 and $35 \mathrm{ft}^{3} / \mathrm{s}$ ), respectively. Public water suppliers are required to provide groundwater pumping information to OWRD. Pumping volumes were reported for single wells or group of wells. Each reported volume was associated with a well log or set of logs, so the location and depth of pumping could be established. In cases where data were missing from the record, values were estimated by interpolating between prior and later periods. In instances where a single pumping volume was reported for a group of wells, the volume was proportioned between the wells on the basis of their reported capacities. Private domestic wells were not included in the model because of its extremely small influence. Gannett and others (2001) estimated total private domestic well pumping at about $5.3 \mathrm{ft}^{3} / \mathrm{s}$ (3,800 acre-ft/yr) based on census data. Much of this returns to the saturated zone through on-site septic systems. A more complete description of methods used to estimate public water supply pumping is in Gannett and others (2001). Recent trends in pumping and associated impacts are described by Gannett and Lite (2013).

Irrigation pumping from 1978 through 1997 was estimated by Gannett and others (2001) for use in the 2004 model. Pumping volumes were based on irrigation water-use estimates determined using satellite imagery, water-rights maps, field data collection, and information on irrigation methods and associated efficiency. High- and mediumwater-use crops were identified using two satellite images from the 1994 growing season. These crop classifications were-associated with specific crops based on county crop statistics and field visits. Crop water requirements were based on literature values for the area (for example, Cuenca and others, 1992). To estimate water application rates, the crop water requirements were adjusted to account for irrigation efficiency. Water-use estimates were compared with water-rights maps from OWRD to establish the source as either surface water or groundwater for specific land parcels. For groundwater rights, the required water volumes for the irrigated parcels included in the right were assigned specific wells associated with the right. It was assumed that pumping did not exceed the crop water requirement adjusted for irrigation efficiency. Annual pumping estimates from the 1994 analysis were extrapolated forward and backward in time for the 2004 model based on the priority dates of associated water rights. Interannual rates were varied to reflect year-toyear climate variability using potential evapotranspiration (PET) estimates from the Reclamation AgriMet station near Madras (Bureau of Reclamation, 2016). Estimates include primary groundwater rights only. Supplemental rights are not included. Gannett and others (2001) provide a more complete description of the methods used to estimate irrigation pumping.

The period of estimated irrigation pumping was extended from 1978 to 1997 through 2008 for an analysis of groundwater level changes by Gannett and Lite (2013). For that effort, statistics on crop types and associated water use for each county determined in the 2001 study were used to calculate the additional use by new water rights established each year. There was no adjustment for year-to-year variations due to climate.

Annual irrigation pumping estimates were extended through 2013 for this project as previously described here. Whereas the previous two studies required only total annual or irrigation season volumes, the present effort required monthly 
data. Annual totals were parsed into monthly volumes during the irrigation season using PET estimates from AgriMet stations at Madras, Powell Buttes, and Bend (Bureau of Reclamation, 2016). The total volume of water pumped from a well was distributed monthly based on each month's percentage of total irrigation season PET.

Groundwater pumping is applied to the model using the MODFLOW WEL package. Row, column, and layers were assigned based on the geographic location and depth of each well. Many wells have open intervals that span more than one model layer. Upper model layers are commonly not saturated, and analysis of well logs suggests that production zones are commonly near or at the bottom of the well. For these reasons, the pumping was assigned to the lowermost layer for a particular well.

\section{Head-Dependent Flow Boundaries}

Head-dependent flow boundaries are those across which the flow to or from the groundwater system varies with the head in the associated grid cell. In the GSFLOW model, streams are the only head-dependent flow boundary explicitly simulated by MODFLOW.

Streams are simulated in the model using the MODFLOW streamflow-routing package (SFR2; Niswonger and Prudic, 2010). This package simulates movement of water between the stream and the aquifer system, and routes water through the stream network. The rate of water movement between the stream and aquifer system is the product of the difference between the stage of the stream and the head in the underlying aquifer and the streambed conductance. Streambed conductance is the product of the reach length, reach width, and hydraulic conductivity, divided by the streambed thickness.

The simulated stream network includes 118 stream segments (sections of stream from the headwaters to a confluence, or between confluences) and 1,969 stream reaches (sections of a stream in a particular model cell). Streams occupy 1,852 cells in the model (a single cell can contain more than one stream reach). The MODFLOW stream network matches the rasterized stream network developed from the model grid used with the cascade routing tool.

Streambed elevations and slopes were determined using the 10-m DEM, assuming a 5-ft stream depth. A constant streambed thickness of $10 \mathrm{ft}$ was used throughout the model. Channel widths were measured using aerial images. Stream stage in each reach is calculated by the model using Manning's equation for open-channel flow assuming a rectangular channel and a constant roughness coefficient of 0.04 .
Lakes and reservoirs are not simulated in the model. At the time of this project, the MODFLOW reservoir package was not available for use with GSFLOW, and implementing the lake package (which requires significant data) was not warranted given the original intent and scope of the project. The lakes and reservoirs in the southern part of the study area, including Crescent Lake, Odell Lake, Davis Lake, Cultus Lake, and Crane Prairie and Wickiup Reservoirs, are represented as simple stream reaches as part of the SFR2 package previously described. Groundwater can move to or from the stream system in the areas of the lakes and reservoirs and water is routed through them. There is no capability to simulate storage in these features. This capability could be added in the future by implementing the lake package.

Lake Billy Chinook, the reservoir behind Round Butte Dam that inundates the confluence of the Deschutes, Crooked, and Metolius Rivers, is explicitly simulated in the model. The reservoir is quite deep (350 ft near the dam) and spans multiple MODFLOW model layers. Lake Billy Chinook is an important head-dependent boundary in this area and the locus of significant groundwater discharge. Round Butte Dam is operated for hydroelectric generation and not flood control, consequently, the reservoir elevation is held relatively constant at about 1,945 ft. Changes in reservoir storage are small and not important to the simulations.

Lake Billy Chinook was simulated by assigning all model cells associated with the lake with very large vertical and horizontal hydraulic conductivities and setting the SFR2 elevation to correspond to the normal pool elevation. In this manner, the reservoir behaves as a constant head boundary and groundwater entering the lake domain is routed to the stream.

\section{Geologic Zonation}

The hydraulic characteristics of subsurface geologic materials, vertical and horizontal hydraulic conductivity and storage characteristics, are represented in the model using a zone approach in which the model domain is divided into 20 zones. Hydraulic characteristics are considered homogeneous in each zone. Although hydraulic characteristics actually vary continuously in space, there are no data with which to practically create such a representation. The zones in this model (fig. 10 and table 3) are largely inherited from the 2004 model that were based on the hydrogeologic unit mapping of Lite and Gannett (2002), depositional facies of the Deschutes Formation from Smith (1986), stratigraphy, and hydraulic head distribution. The zonation from the 2004 model was refined for this project based on improved understanding of the hydrogeology, as well as improved capabilities of MODFLOW to simulate faults. 

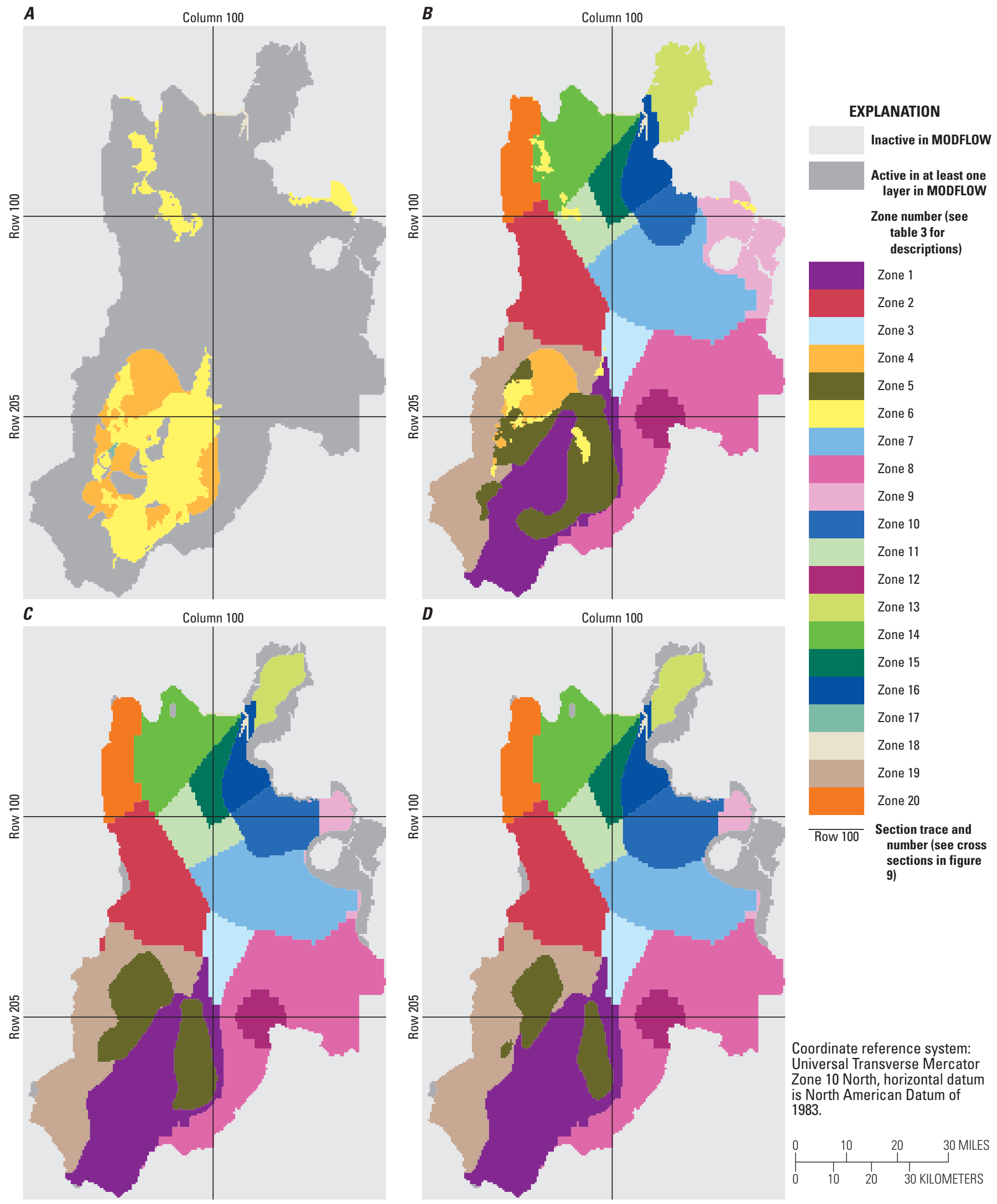

Figure 10. Zonation of hydrogeology used in the MODFLOW model, upper Deschutes Basin, Oregon. Figures $10 A-H$ correspond to model layers 1 through 8. Cells that are active in at least one layer or are inactive in MODFLOW are also shown. 

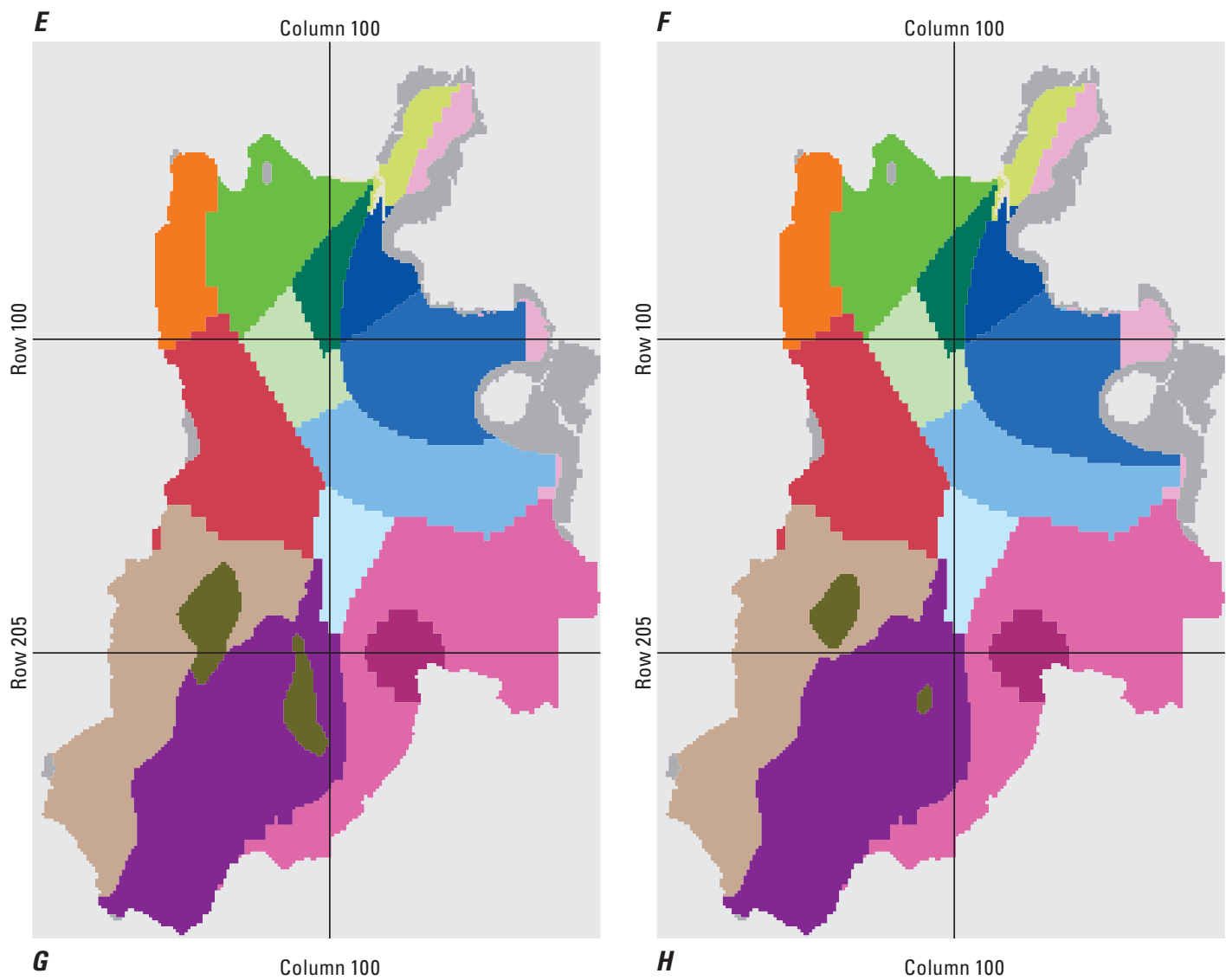

\begin{tabular}{|c|}
\hline $\begin{array}{c}\text { EXPLANATION } \\
\text { Inactive in MODFLOW }\end{array}$ \\
$\begin{array}{c}\text { Active in at least one } \\
\text { layer in MODFLW } \\
\text { Zone number (see } \\
\text { table } 3 \text { for } \\
\text { descriptions) } \\
\text { Zone } 1 \\
\text { Zone } 2 \\
\text { Zone } 3 \\
\text { Zone } 5 \\
\text { Zone } 7 \\
\text { Zone } 8 \\
\text { Zone } 9 \\
\text { Zone } 10 \\
\text { Zone } 11 \\
\text { Zone } 12 \\
\text { Zone } 13 \\
\text { Zone } 14 \\
\text { Zone } 15 \\
\text { Zone } 16 \\
\text { Zone } 18 \\
\text { Zone } 19 \\
\text { Zone } 20 \\
\text { Section trace and } \\
\text { number (see cross } \\
\text { sections in figure 9) }\end{array}$ \\
\hline Row 100 \\
\hline
\end{tabular}
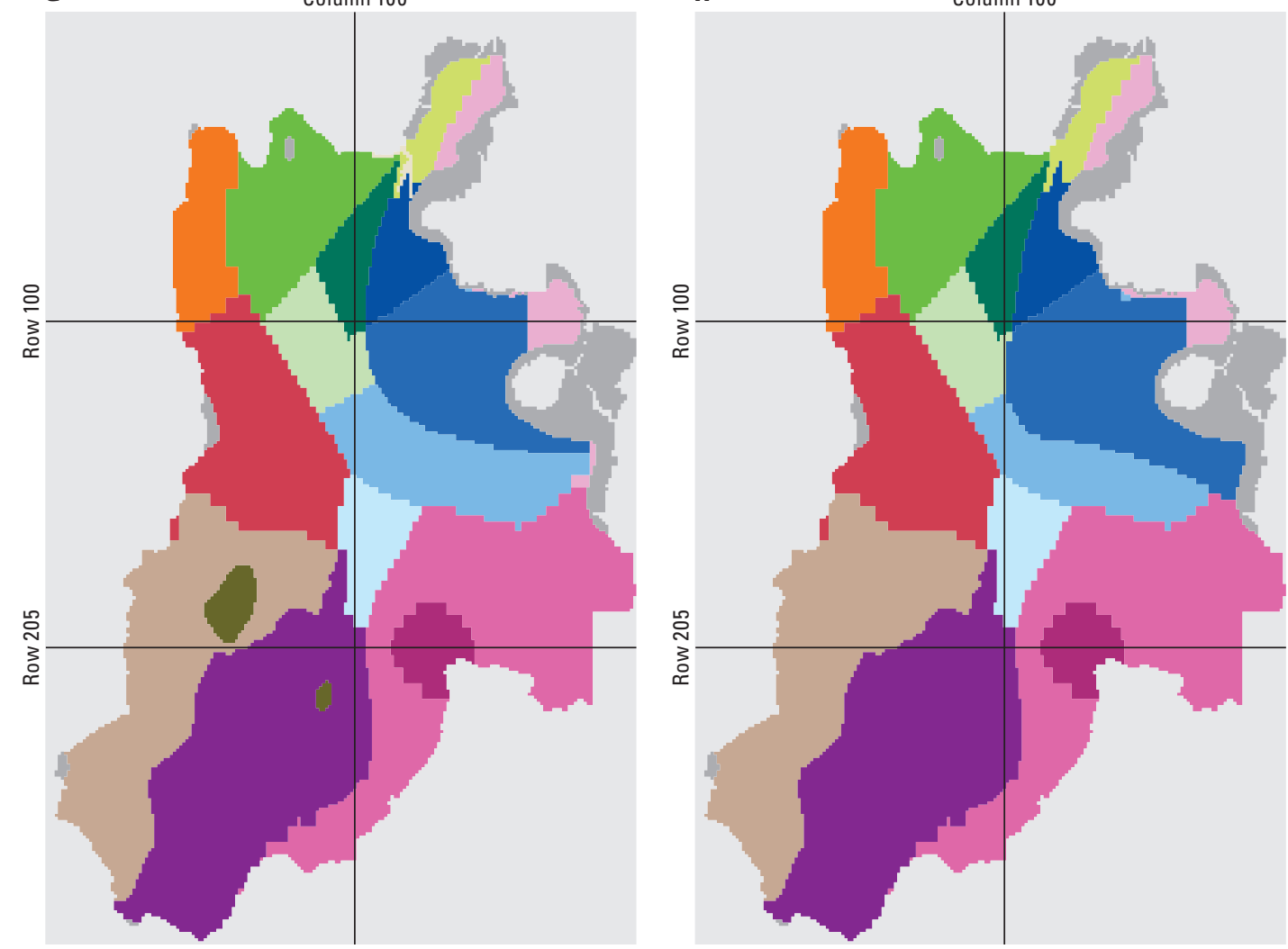

Coordinate reference system: Universal Transverse Mercator Zone 10 North, horizontal datum is North American Datum of 1983.

\begin{tabular}{|c|c|c|c|}
\hline ? & 10 & 20 & 30 MILES \\
\hline & 10 & & $O M E$ \\
\hline
\end{tabular}

Figure 10.-Continued 
The original 2004 model contained 17 separate zones, one of which consisted of a section of low-permeability cells to represent the Green Ridge fault zone. The current model has 20 zones. The Green Ridge and Sisters fault zones are now simulated in all layers using the Horizontal Flow Barrier (HFB) package (Hsieh and Freckleton, 1993), so there is no corresponding zone in the current model. There is, however, a separate zone in the new model to represent Lake Billy Chinook, as previously described.

The current zonation scheme differs from the 2004 model in two ways. First, the representation of surficial deposits is improved by better information on, and representation of, the thickness and distribution of the glacial outwash and alluvial deposits. In the original model, these deposits were represented as a uniform 100-ft thick in the uppermost layer. In the current model, they vary in thickness and are included in multiple layers based on surface geologic mapping and well information. The second principal change to the zonation scheme is in the representation of the previously described graben-filling sediments in the La Pine subbasin in the southern part of the study area. In the 2004 model, this mass of sediment was represented by a single zone that encompassed much of the entire southern part of the model and penetrated the entire model thickness below layer 1 . In the present model, the graben-filling deposits have a more complex geometry, change extent with depth, and do not extend to the bottommost layer of the model.

There are other small changes to boundaries between zones made during calibration. The Cascade Range now comprises three zones instead of two. Zone 9, which included a small area north of Powell Buttes in the 2004 model, now extends eastward to include Prineville and areas east of Powell Buttes (fig. 10).

\section{Model Calibration}

The model was calibrated using traditional trial and error methods. Parameter estimation techniques were not practical for the coupled GSFLOW model because of the long run times, and were not useful for PRMS-only runs because of the large groundwater influences on gaged flows. The calibration process started with the calibration of surface processes and basin-wide mass balance in PRMS-only runs. Once integrated with GSFLOW, further calibration of PRMS was carried out to obtain necessary groundwater recharge for MODFLOW. After groundwater recharge was reasonably close, the MODFLOW model was calibrated to improve the fit to the distribution and magnitude of discharge to streams and observed hydraulic heads.

\section{PRMS Calibration}

The initial calibration of PRMS ensured that surface processes were being simulated properly and that the basinwide water balance was correct. Calibrating subbasin water balances in PRMS-only runs was not possible because of the large volumes of groundwater moving between subbasins. Flow at the northern extent of the model, however, includes all runoff and regional groundwater flow from the upper basin, so a comparison of annual water balances at that point was useful for initial calibration.

Calibration data for the PRMS model consisted of precipitation, solar radiation, evapotranspiration estimates, and snowpack measurements (table 4), and streamflow (table 1). Precipitation and snowpack data were available from seven snow telemetry (SNOTEL) sites operated by the Natural Resources Conservation Service in or immediately adjacent to the active model domain (Natural Resources Conservation Service, 2016). Solar radiation data were available from three AgriMet sites operated by the Reclamation near Bend, Powell Butte, and Madras (Bureau of Reclamation, 2016). Evapotranspiration estimates were from Farnsworth and others (1982).

The data previously described here were used to check the associated surface processes in PRMS. The spatial distribution of precipitation in the PRMS model was highly constrained by the dense placement of the 587 meteorological data input locations on 3 arc-minute centers as previously described. Simulated seasonal distribution of precipitation from 2000-13 compared favorably with observations at 9 sites evaluated. Simulated mean monthly precipitation was generally close to or slightly larger than measured. Annual totals were within 4 percent at 5 sites including all those with the most precipitation (63-74 in/yr). Simulated mean annual totals exceeded measured totals at 4 sites by 14-26 percent. It is possible these discrepancies result from errors in the distribution of precipitation in the DayMet dataset. Adjustments to precipitation are discussed later in this section.

The PRMS model simulated solar radiation using the modified degree-day (ddsolrad) option (Markstrom and others, 2015). The monthly parameters for this option (dday_slope and dday_intcp) were initially set using monthly estimated normal incident solar radiation data (National Renewable Energy Laboratory, 2017). Model default values for these two parameters were iteratively adjusted until the mean-monthly values of simulated daily basin-wide solar radiation (basin potsw) closely matched monthly National Renewable Energy Laboratory (NREL) estimated solar radiation data. The NREL data were downloaded from the GDP. These parameters were then further adjusted to improve fit to measured solar radiation 
Table 4. Sources of snowpack and solar radiation measurements used to calibrate the PRMS model, upper Deschutes Basin, Oregon.

[Data type: Snow water equivalent and precipitation data from the Natural Resources Conservation Service (www.nrcs.usda.gov/wps/portal/ nrcs/detail/or/snow/); Solar radiation and precipitation data from the Bureau of Reclamation (www.usbr.gov/pn/agrimet/). Elevation in feet above National Geodetic Vertical Datum of 1929. L atitude and L ongitude in decimal degrees. HR U is hydrologic response unit]

\begin{tabular}{|c|c|c|c|c|c|c|}
\hline Data type & $\begin{array}{l}\text { Site name and (or) } \\
\text { agency designation }\end{array}$ & $\begin{array}{l}\text { Period of } \\
\text { record }\end{array}$ & Elevation & Latitude & Longitude & HRU \\
\hline \multirow[t]{7}{*}{ Snow water equivalent and precipitation } & Cascade Summit & 1981-present & 5,100 & 43.59 & 122.06 & 44095 \\
\hline & Chemult Alternate & 1981-present & 4,850 & 43.23 & 121.81 & 56670 \\
\hline & Hogg Pass & 1980-present & 4,790 & 44.42 & 121.86 & 14860 \\
\hline & Irish Taylor & 1979-present & 5,540 & 43.8 & 121.95 & 36701 \\
\hline & New Crescent Lake & 1981-present & 4,910 & 43.51 & 121.98 & 46956 \\
\hline & Summit Lake & 1979-present & 5,610 & 43.45 & 122.14 & 49024 \\
\hline & Three Creeks Meadow & 1981-present & 5,690 & 44.14 & 121.64 & 24580 \\
\hline \multirow[t]{3}{*}{ Solar radiation and precipitation } & Bend, OR (bewo) & 2003-present & 3,619 & 44.05 & 121.32 & 27853 \\
\hline & Madras, OR (mrso) & 1984-present & 2,439 & 44.68 & 121.15 & 5453 \\
\hline & Powell Butte, OR (pobo) & 1993-present & 3,199 & 44.25 & 120.95 & 20491 \\
\hline
\end{tabular}

values at AgriMet sites near Bend, Madras and Powell Butte. Solar radiation parameters were not further adjusted during subsequent calibration steps.

The PRMS model simulated PET using the Jensen-Haise option (Markstrom and others, 2015). The monthly parameter for this option (jh_coef) was calibrated using mean-monthly PET data (Farnsworth and others, 1982; Farnsworth and Thompson, 1982). These monthly evaporation values were available and downloaded using the GDP. The GDP also computed weighted-average estimates of potential evaporation for the entire study area. The $j h \_$coef parameter was iteratively adjusted until the mean-monthly values of simulated daily basin-wide potential evapotranspiration (basin_potet) closely matched monthly evaporation data from the GDP. A second parameter (jh_hru_coef) was adjusted during calibration of the integrated model to improve overall hydrologic budget fit.

Simulated snow accumulation was adjusted using the parameters tmax_allsnow, which defines the monthly maximum air temperature below which precipitation is simulated as all snow, and tmax_allrain, which defines the maximum air temperature above which all precipitation is simulated as rain. These were adjusted to provide a reasonable overall fit to monthly snow totals at the seven SNOTEL sites (table 4). Snow parameters were adjusted during the initial PRMS calibration and then further adjusted during the calibration of the integrated model.

Streamflow data were of limited use during the initial PRMS calibration phase because of the large amount of groundwater moving between subbasins and its influence on distribution and timing of discharge. This issue was not a problem during calibration of the integrated model because the groundwater component of flow was simulated. Flow at the lowermost gage point in the model (the Deschutes River near Madras) includes virtually all the groundwater discharge from the upper Deschutes Basin, so groundwater exchange between subbasins has less effect on the annual mass balance at that location. Because of this, the simulated and observed annual flows of the entire basin could be checked during initial PRMS calibration steps. Once the PRMS surface processes were being simulated correctly and the overall mass balance was close, effort focused on the MODFLOW calibration. Final PRMS parameters are in table 2. 


\section{Modflow Calibration}

\section{Head Data}

Simulated heads were calibrated using 5,485 water-level measurements from 800 wells (fig. 11). Only static water levels were used. Time-series measurements were available for 501 wells, 144 of which had 10 or more measurements. Of the wells with 10 or more measurements, the periods of record ranged from 1.4 to 34 years, with a median of 13.4 years. Many of the wells were monitored intensively during previous projects so there were periods of more frequent monitoring activity in the late 1970s and early 1990s. About 65 wells with various periods of record were being monitored as of 2012. All water-level data were from the USGS National Water Information System (U.S. Geological Survey 2017) and from the OWRD groundwater data base (Oregon Water Resources Department, 2017).

\section{Flow Data}

The GSFLOW model was calibrated using information on daily streamflow values throughout the basin as well as additional information from miscellaneous streamflow measurements and seepage runs. Streamflow data provide information on the temporal variations in groundwater discharge and runoff, whereas the miscellaneous measurements and seepage runs provide additional information on the geographic distribution of stream gains and losses.

This model was set up to simulate, as closely as practical, natural conditions in the basin. This means that reservoir operations and diversions are not simulated. Certain anthropogenic factors that affect water levels in wells, such as pumping and canal leakage, were included in the model because their effects cannot be practically removed from the water-level measurements. In contrast, the effects of reservoirs and diversions on streamflow could be removed using reconstructed flow time series developed by Reclamation at 14 locations in the basin (table 1) (Bonneville Power Administration, 2017; Bureau of Reclamation, 2017). These corrected flows are referred to as naturalized flows throughout this report. The naturalized flows do not account for bank storage effects at reservoirs. The naturalized flows provide reasonable calibration targets for this model, but should not be expected to have the accuracy of actual streamgage data.
The geographic distribution of groundwater discharge to streams described in the preceding section, "Groundwater Movement to and from Streams," was developed primarily from seepage runs made by OWRD and summarized by Gannett and others (2001), and augmented by more recent data for Tumalo Creek collected by OWRD (Rich Marvin, Oregon Water Resources Department, written commun., 2015). This information was used during the MODFLOW calibration to help ensure that the geographic distribution of gaining and losing stream reaches was simulated properly.

\section{GSFLOW Calibration Process}

The MODFLOW model was initially set up using parameter values from the 2004 model. The initial GSFLOW calibration phase consisted of adjusting PRMS and MODFLOW parameters that control the movement of water from the soil zone to the saturated zone. Key parameters were snowinfil_max, pref_flow_den, soil2gw_rate, soil2gw_max, and VKS. These parameters were set at values that resulted in the necessary large recharge and limited interflow and runoff. This is consistent with the observed conditions in the basin, where large areas have only a sparse and locally disconnected surface drainage network (O’Connor and others, 2003), as well as other modeling efforts showing recharge rates up to 70 percent of the annual precipitation (Manga, 1997; Gannett and others, 2001).

The GSFLOW model was calibrated to achieve a balance between hydraulic head distribution, the geographic distribution and rates of stream gains and losses, and the temporal variations in streamflow. Once recharge rates were generally correct, the timing of discharge was improved by adjusting snow and evapotranspiration (ET) parameters as well as the groundwater storage parameters (specific storage and specific yield). The head distribution, which has a large influence on the geographic distribution of groundwater discharge, was improved by adjusting hydraulic conductivity values and vertical anisotropy. Spatial distribution of stream gains and losses was also refined by adjusting streambed hydraulic conductivity values. Final MODFLOW parameter values are shown in table 3. Exact comparisons of parameter values between the MODFLOW model of Gannett and Lite (2004) and the GSFLOW model are difficult because of changes in the zonation, layering, and layer-type assignments (all layers were simulated as confined in the 2004 model). 


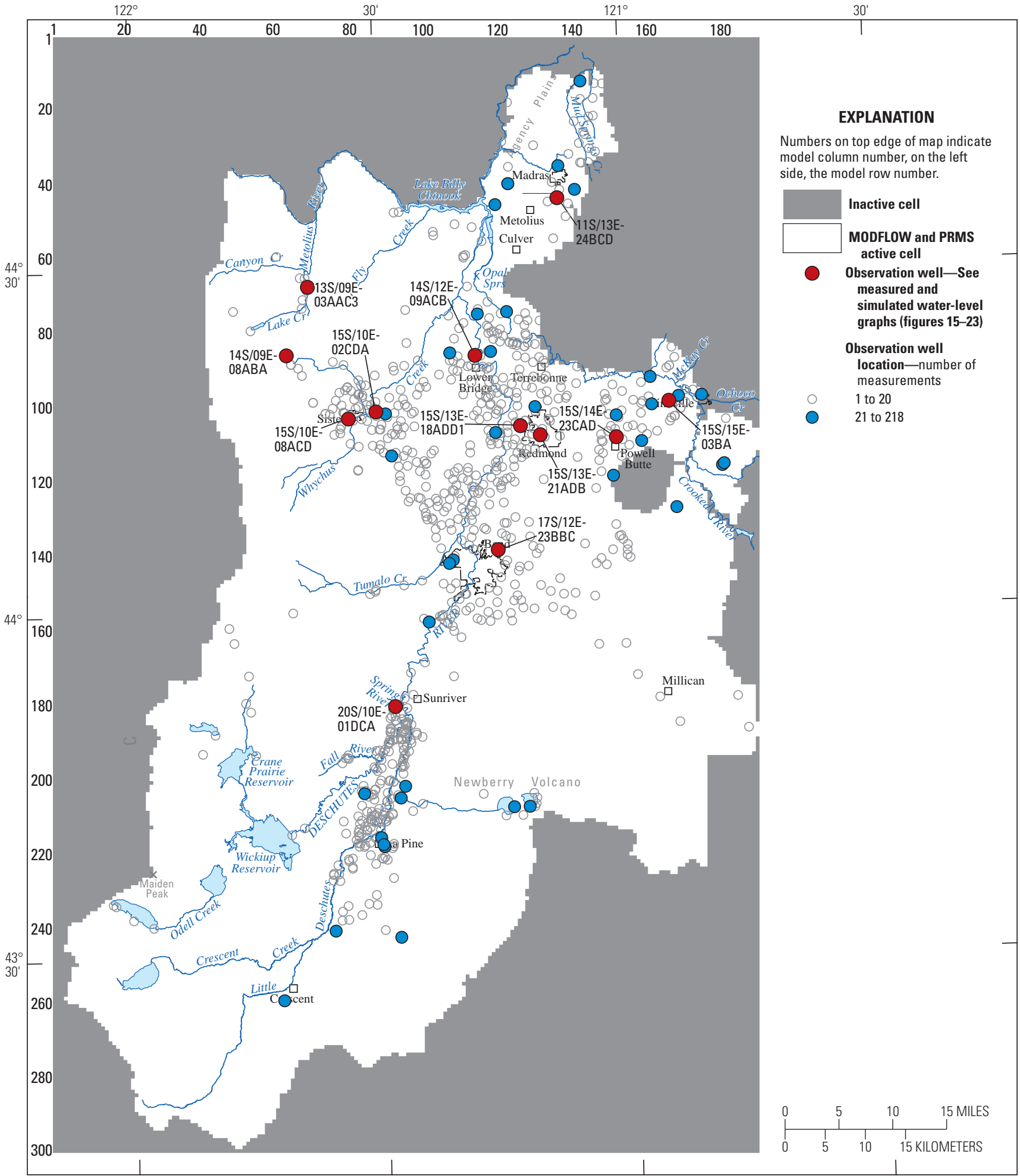

Coordinate reference system: Universal Transverse Mercator Zone 10 North, horizontal datum is Clarke 1866.

Figure 11. Head observation wells used for model calibration, upper Deschutes Basin, Oregon. Labeled wells correspond to figures 15-23 and have greater than 20 measurements. 
However, hydraulic conductivity values are generally of similar magnitude, with a median change of about 23 percent. The largest change (an increase in $\mathrm{K}$ by a factor of about 8 ) was to the surficial sediment (zone 6). This is because the mapped thickness in the current model is much smaller than the uniform $100 \mathrm{ft}$ thickness assigned in the 2004 model. Vertical anisotropy values are also of similar magnitudes in both models, except in the Cascade Range and the Redmond area, where the GSFLOW model values are about an order of magnitude larger, and in the La Pine graben, where values are about an order of magnitude smaller.

\section{Model Fit}

\section{Simulated Heads}

Simulated heads match measured values reasonably well over the more than $5,000 \mathrm{ft}$ of variation across the model domain (fig. 12). The average and median head residuals are -22.6 and -15.4 ft, respectively, and the standard deviation is $116 \mathrm{ft}$. Head residuals (observed minus simulated heads; fig. 13) show a slight negative bias, meaning that overall, simulated heads are too high more commonly than too low. There is no correlation between the bias and elevation. The general negative bias may be due to a combination of large vertical head gradients and the large thickness of layer 2 , which contains most observations.

Maps of head residuals (fig. 14) show that there are some geographic biases in the residuals, with some areas dominated by high or low residuals. This is an unavoidable consequence of the representation of subsurface hydraulic characteristics in discrete zones. In some instances, large residuals may be due to local perched aquifers not simulated by the model.

Transient variations in head are driven by many external stresses including climate, pumping, stream stage, canal leakage, and reservoir operations. Of these, climate is the dominant driver in the upper Deschutes Basin, followed by pumping and canal leakage (Gannett and Lite, 2013). Heads in the northern part of the study area exhibit a multi-decadal rise because of the installation of Round Butte Dam and filling of Lake Billy Chinook.

The influences of stresses vary spatially, in some cases over distances smaller than the hydraulic parameter zonation. As a result, the fit to head fluctuations varies between wells in some zones. Calibration efforts focused on wells with long periods of record and 20 or more measurements. The fit to transient head signals is discussed by geographic area using a subset of the observation wells (fig. 11).

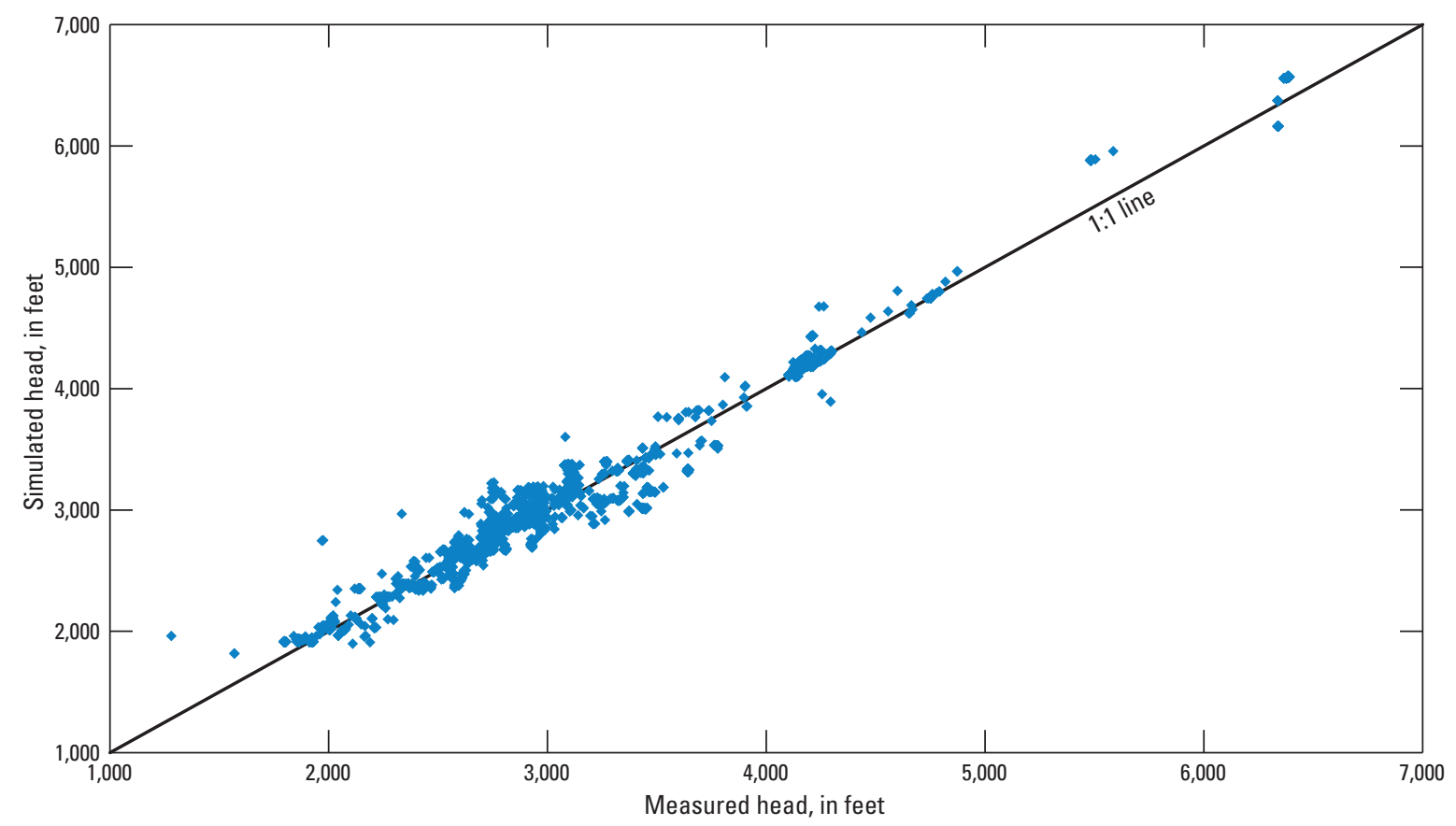

Figure 12. Simulated heads as a function of measured heads, 1980-2013, upper Deschutes Basin, Oregon. 


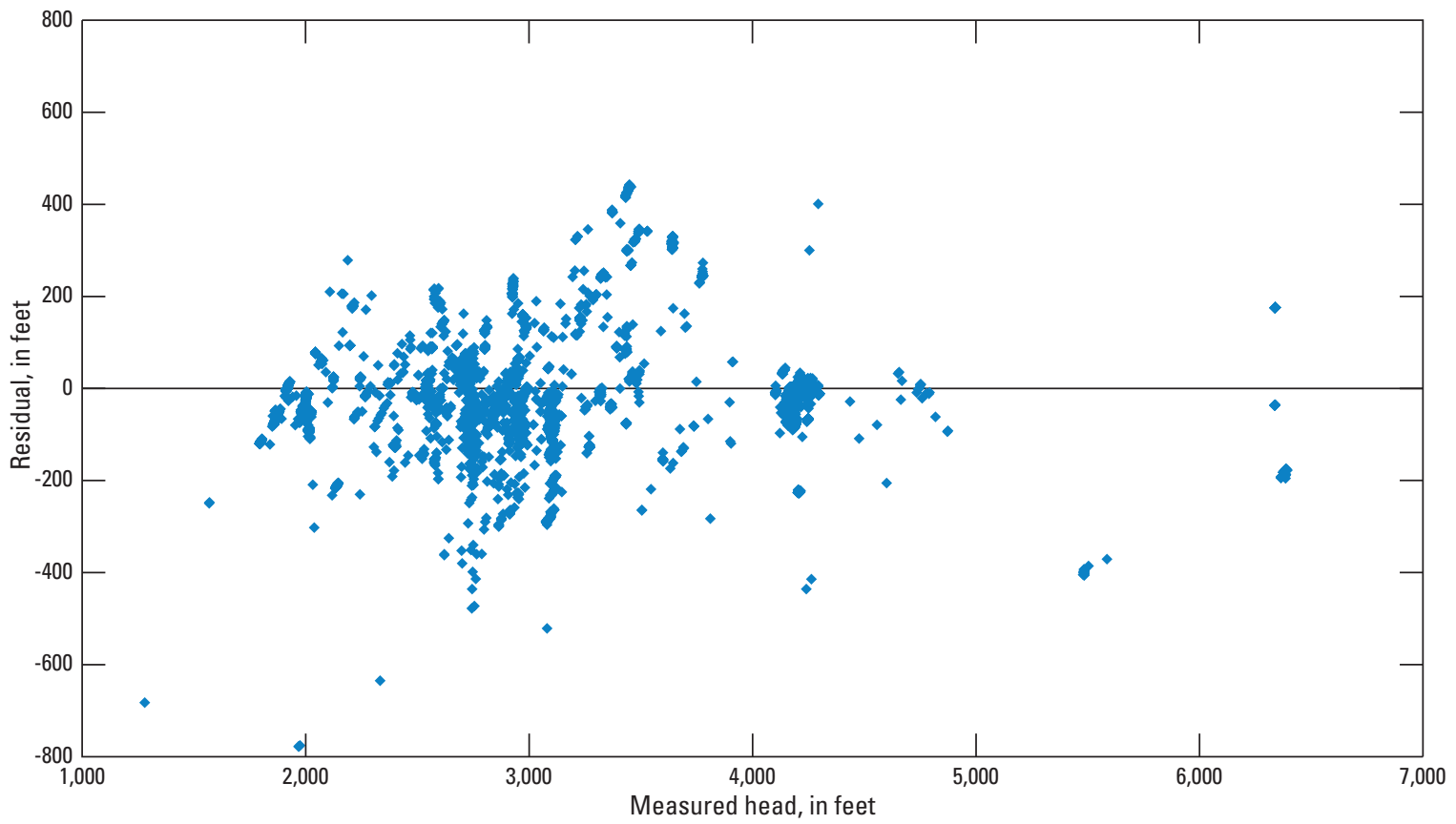

Figure 13. Head residuals (observed minus simulated values) as a function of measured heads, 1980-2013, upper Deschutes Basin, Oregon. 


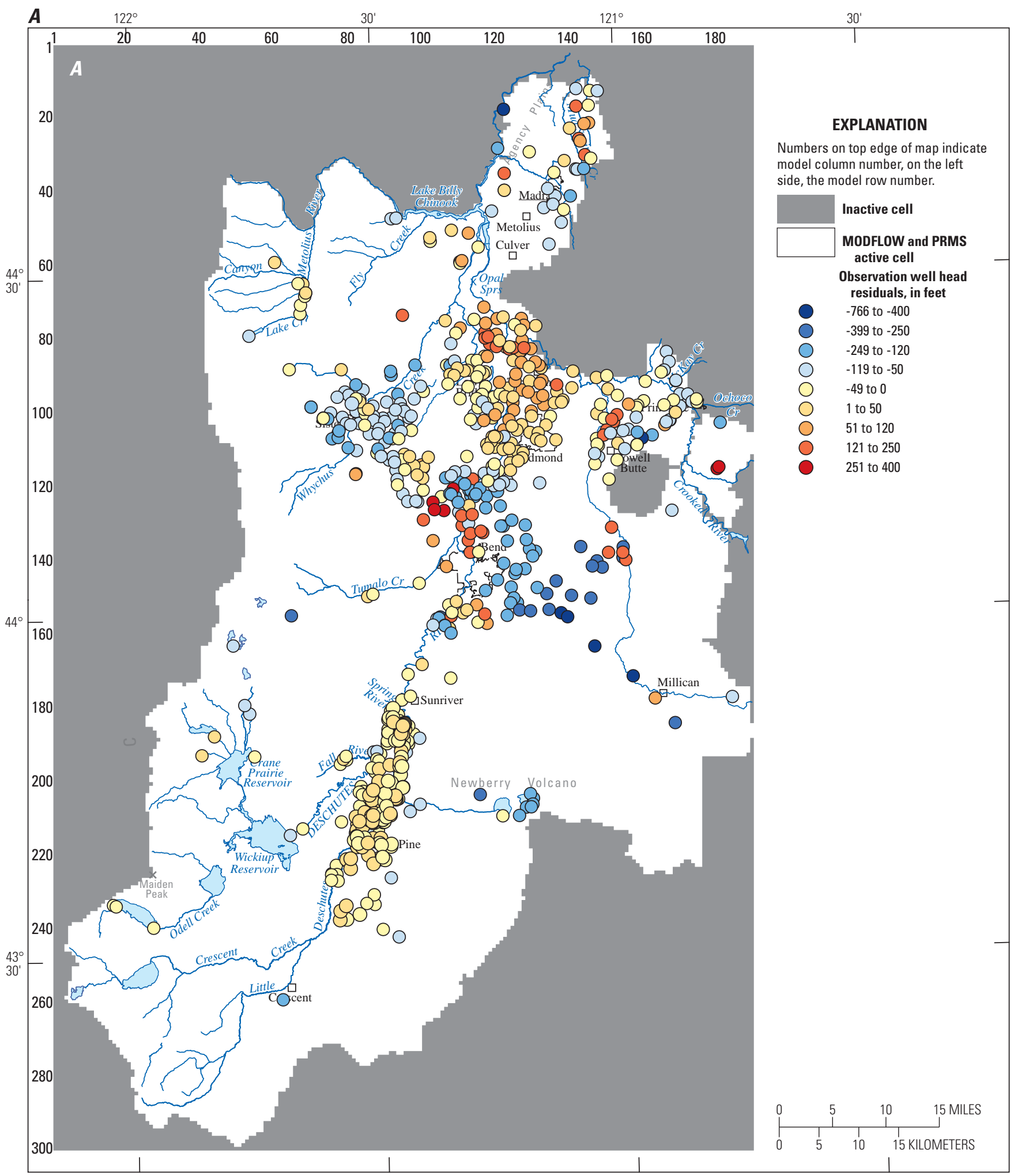

Coordinate reference system: Universal Transverse Mercator Zone 10 North, horizontal datum is North American Datum of 1983.

Figure 14. Head residuals averaged for each observation well, upper Deschutes Basin, Oregon, $(A)$ model layers 1-2, $(B)$ model layers 3-8. MODFLOW, modular groundwater flow model; PRMS, precipitation runoff modeling system. 


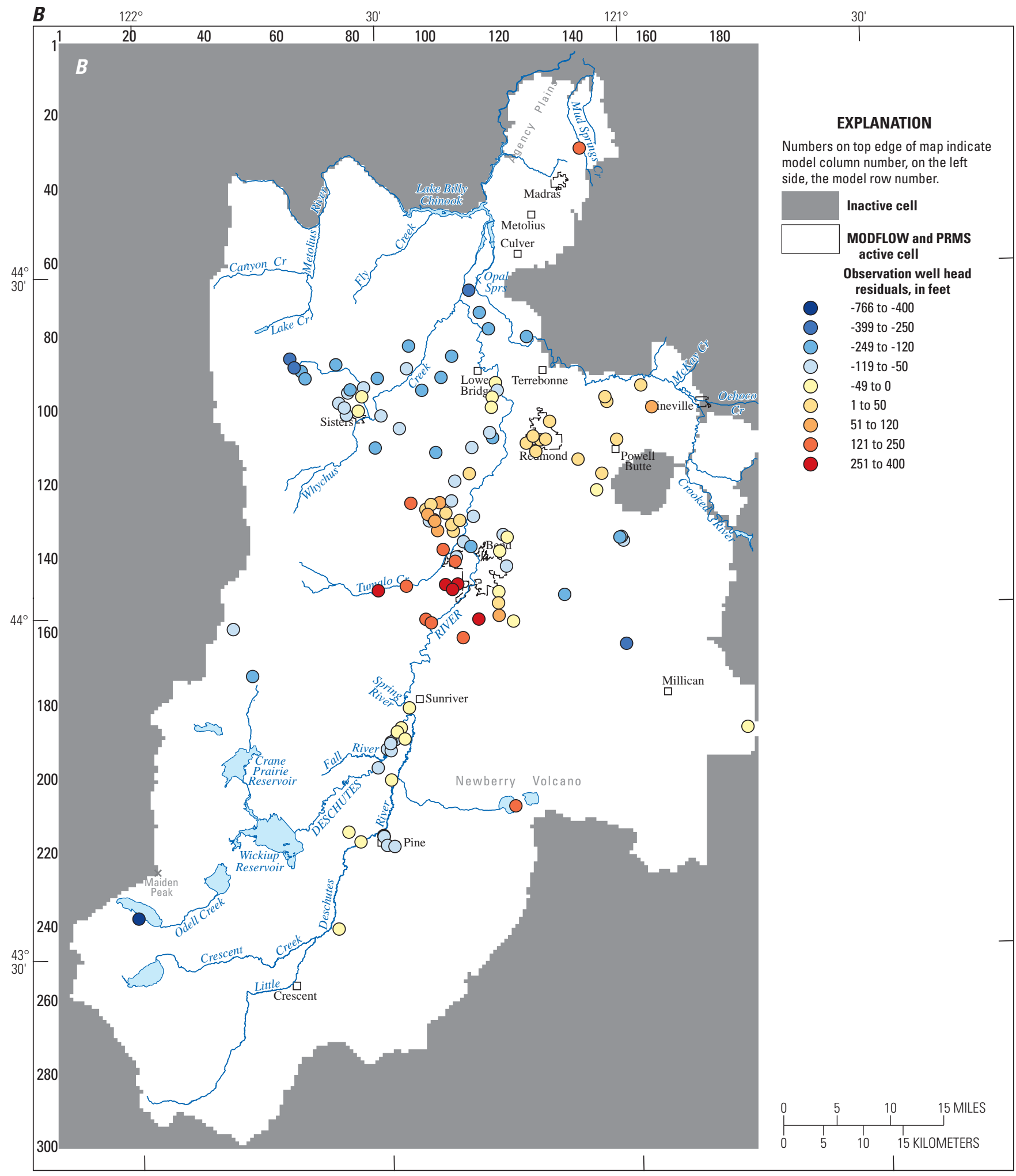

Coordinate reference system: Universal Transverse Mercator Zone 10 North, horizontal datum is North American Datum of 1983.

Figure 14.-Continued 


\section{La Pine Subbasin}

Climate is the predominant factor influencing head elevations in the La Pine subbasin. There are no significant long-term trends, and heads are stabilized by the shallow water table and close proximity to the stream system. Simulated head elevations are generally within a few feet of measured values, and generally match the timing of climate signals in the measurements (fig. 15). The simulated amplitude of the climate signal is slightly muted in some wells.

\section{Bend Area}

Continuous long-term groundwater-level records in the Bend area are sparse. Only one well with a long record was available in the calibration dataset (well 17S/12E23BBC, fig. 16). There is a gap in the record for this well between the late 1990s and early 2000s. The air line used for measurements prior to the gap failed and measurements were not possible until suitable tape access was made available in the early 2000s. The record shows a more or less linear decline of roughly $20 \mathrm{ft}$ between the mid-1990s and 2013 with no seasonal variation. There is some uncertainty in the magnitude of decline because of issues with the air line. Simulated heads show just over $10 \mathrm{ft}$ of decline over this period with no seasonal variation. Other observation wells in the Bend area are shallower and have shorter periods of record than well $17 \mathrm{~S} / 12 \mathrm{E}-23 \mathrm{BBC}$. Neither observations nor simulated values in those wells show trends of the magnitude seen in well 17S/12E-23BBC.
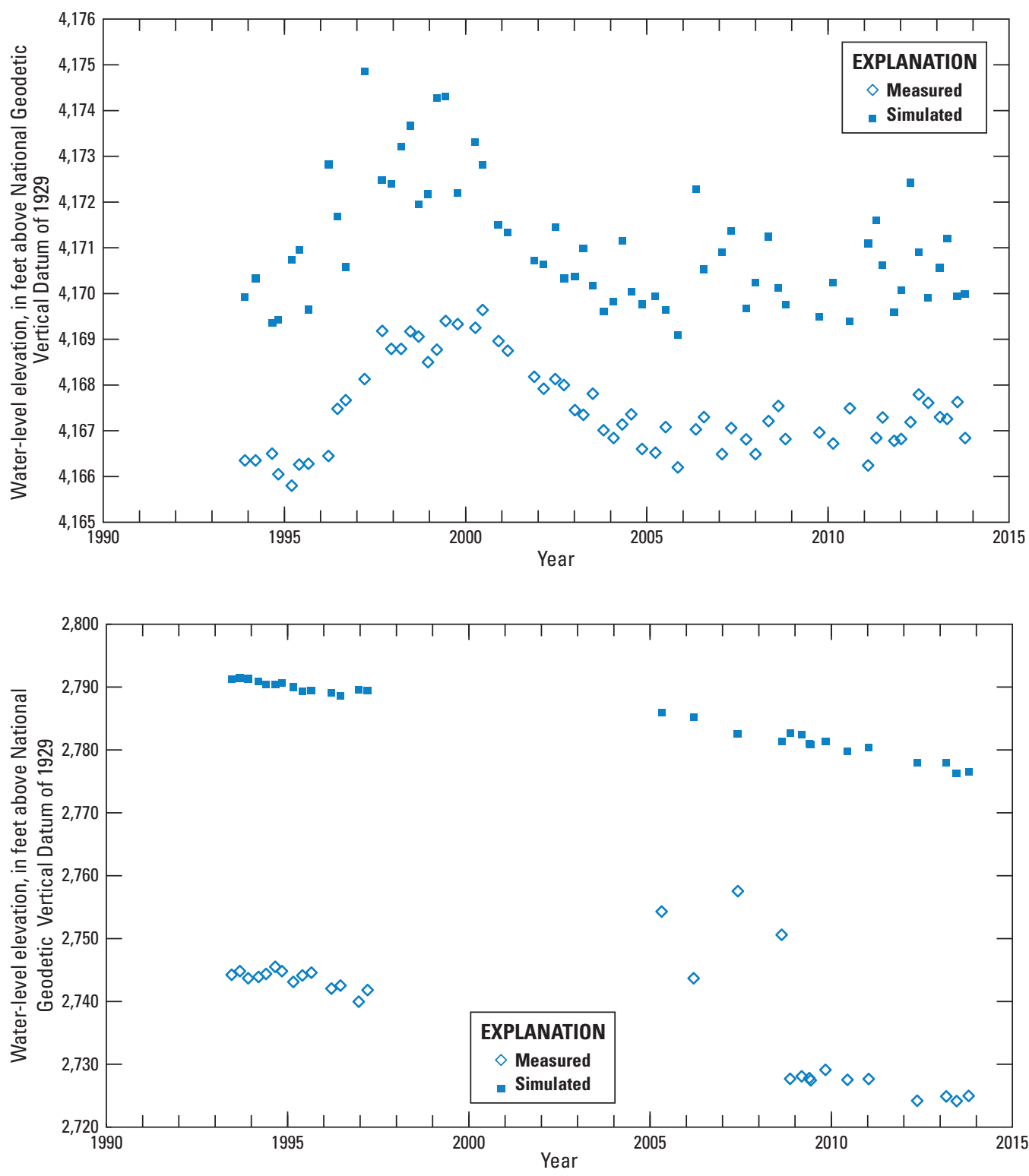

Figure 15. Measured and simulated water levels in observation well 20S/10E-01DCA in the La Pine subbasin, Oregon.
Figure 16. Measured and simulated water levels in observation well 17S/12E23BBC near Bend, Oregon. 


\section{Redmond Area}

Wells in the Redmond area are affected by climate, canal piping, and pumping (Gannett and Lite, 2013). Groundwater levels show a modest and spatially variable decline in recent decades, about $25 \mathrm{ft}$ since 1990 and $15 \mathrm{ft}$ since 2000. This decline abates for several years in the late 1990s in response to wet climate conditions (fig. 17). Simulated heads in the Redmond area match the observed post-1990 decline reasonably well. The late-1990s wet period manifests as a very slight rise in simulated heads.
Water levels in observation wells near Lower Bridge, north of Redmond, also show a combination of climate and pumping influences. Water levels in well 14S/12E-09ACB (fig. 18) exhibit a climate driven rise of about $6 \mathrm{ft}$ in the late-1990s followed by an 8-ft decline from about 2000 to 2013. Simulated water levels match the measured record quite well in this area.
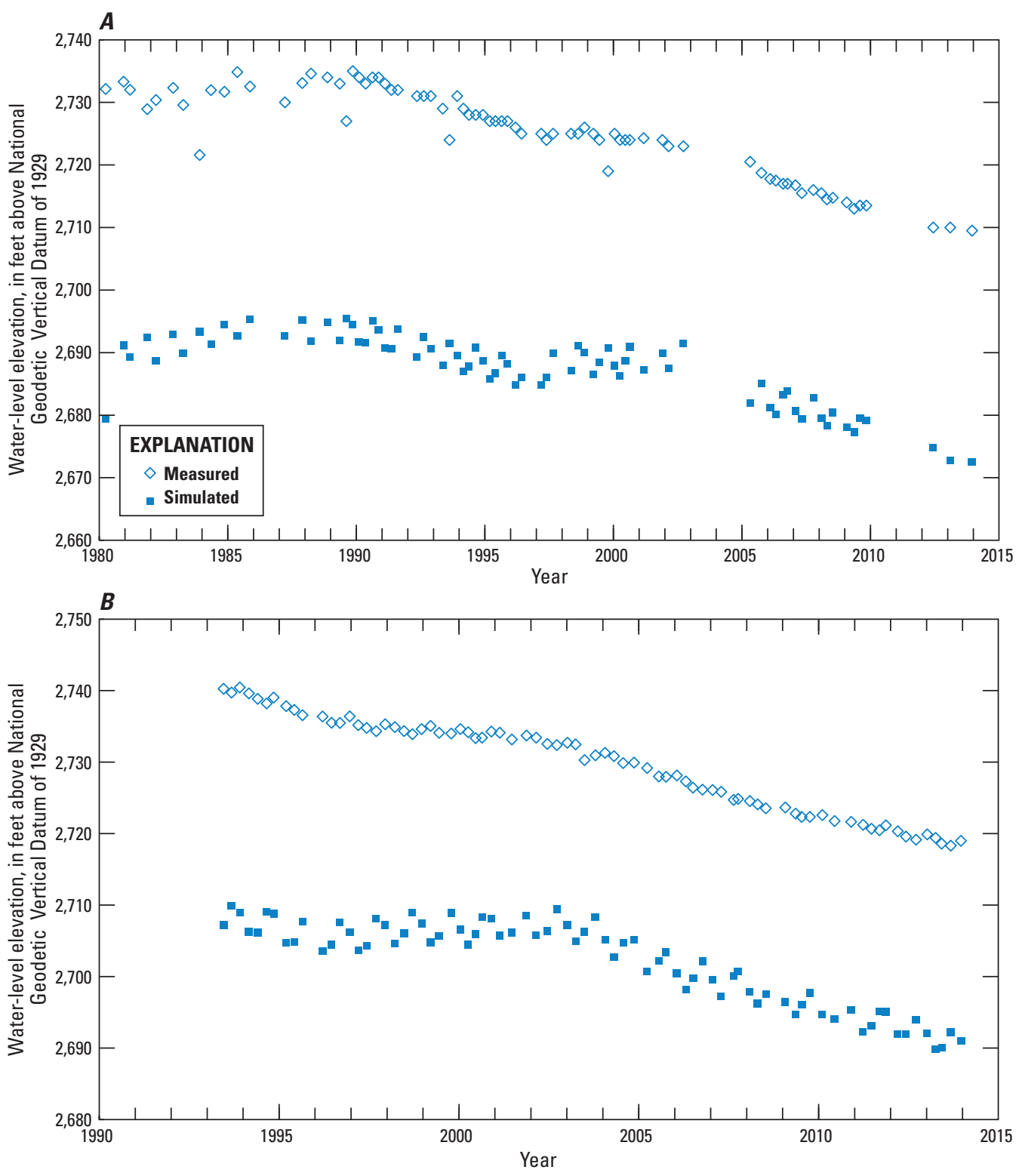

Figure 17. Measured and simulated water levels in observation wells $(A)$ 15S/13E18ADD1 and $(B)$ 15S/13E-21ADB near Redmond, Oregon. 


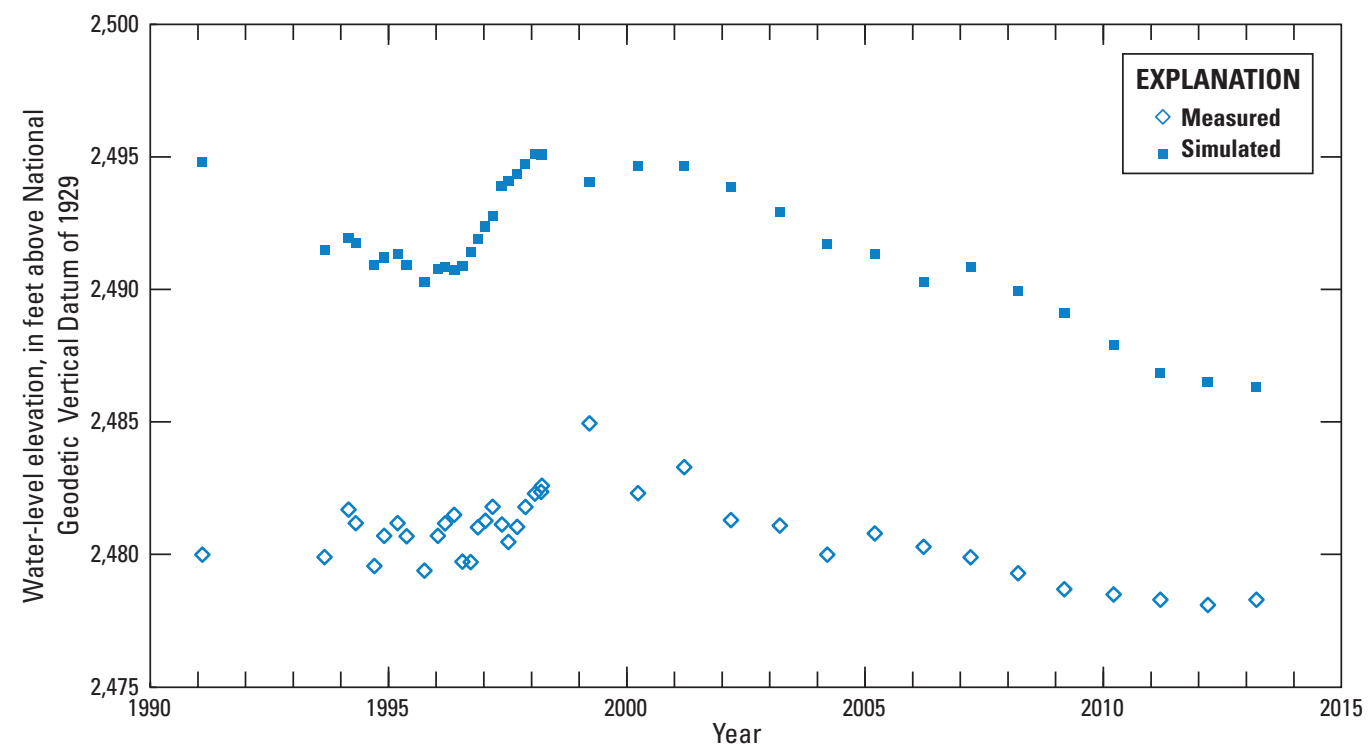

Figure 18. Measured and simulated water levels in observation well 14S/12E-09ACB near Lower Bridge, upper Deschutes Basin, Oregon.

\section{Sisters/Black Butte Area}

Groundwater-level fluctuations are largely driven by climate in the Sisters/Black Butte area, with no evidence of long-term declines in the available data. Simulated water levels match the timing of the climate signal in the measured data, but do not fully capture the amplitude of the fluctuations in all areas. Some of the observation wells in the Sisters area (for example well 15S/10E-08ACD and 15S/10E-02CDA, fig. 19A and $B$ ) exhibit a water-level rise between 2005 and 2013 of a few feet to as much as $15 \mathrm{ft}$. The magnitude of the observed post-2005 rise varies geographically, possibly reflecting local pumping stresses. This post 2005 rise is either not present or is small in simulated water levels.

Wells in the Black Butte area northwest of Sisters exhibit similar climate driven water-level fluctuations. Simulated water levels in well 14S/09E-08ABA (fig. 20) south of Black Butte capture the timing of the climate-driven rise and decline of water levels between the mid-1990s and mid-2000s, but only capture part of the post 2005 water-level rise. 

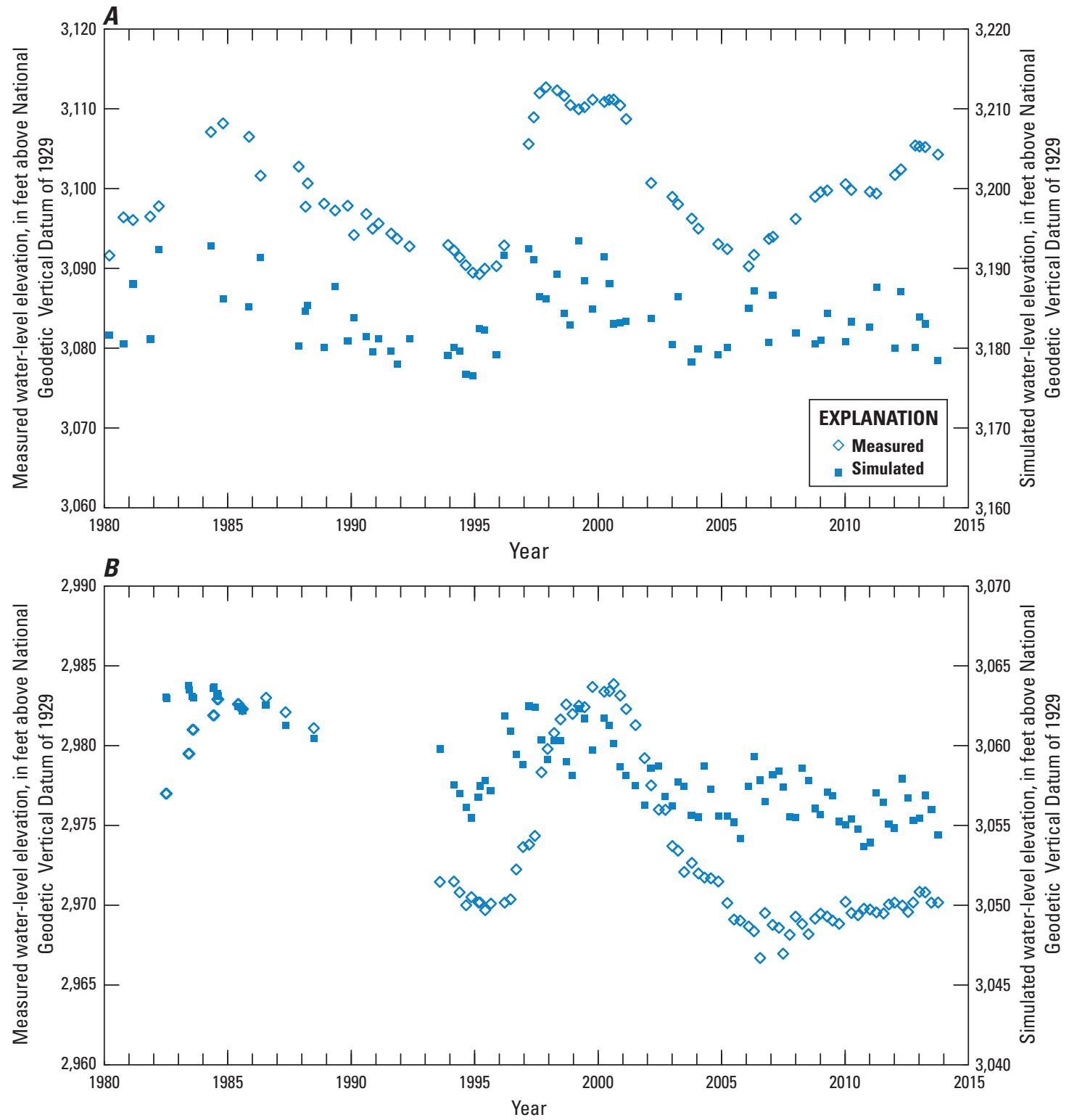

Figure 19. Measured and simulated water levels observation wells $(A)$ 15S/10E-08ACD and $(B)$ 15S/10E-02CDA near Sisters, Oregon. 


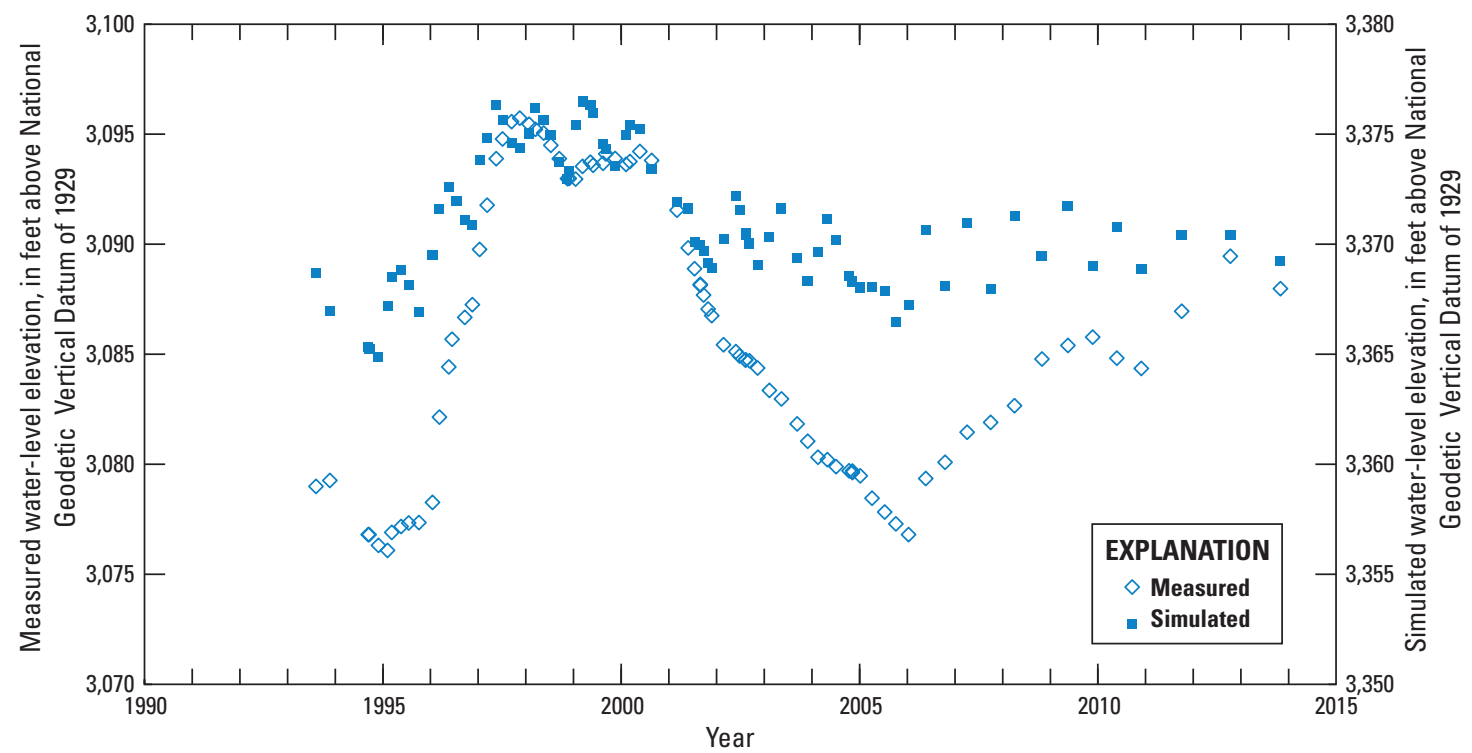

Figure 20. Measured and simulated water levels in observation well 14S/09E-08ABA near Black Butte, Oregon.

\section{Upper Metolius River Area}

Groundwater levels in the upper Metolius River area north of Black Butte are generally stable with little temporal variation. This stability is due to the presence of the Metolius River, a major head-dependent boundary. Well 13S/09E03AAC3 shows a rise less than a foot between 2006 and 2013 (fig. 21). Simulations closely match the absolute water levels and measured rise.

\section{Northern Area}

Many monitored wells in the northernmost part of the model, represented mostly by zone 13 (fig. 10), exhibit rising water levels. The rising trend, as much as $20 \mathrm{ft}$ since the mid-1980s, is the continued response to filling the $400 \mathrm{ft}$ deep reservoir behind Round Butte Dam, Lake Billy Chinook, in 1964. The rise is most prominent closest to the reservoir but is present over much of the zone except the easternmost part. This major change in boundary conditions, which occurred prior to the calibration period, is not simulated in the model. In the areas unaffected by the residual effects of filling Lake Billy Chinook, the model does a good job of simulating the relatively stable water levels (fig. 22). 


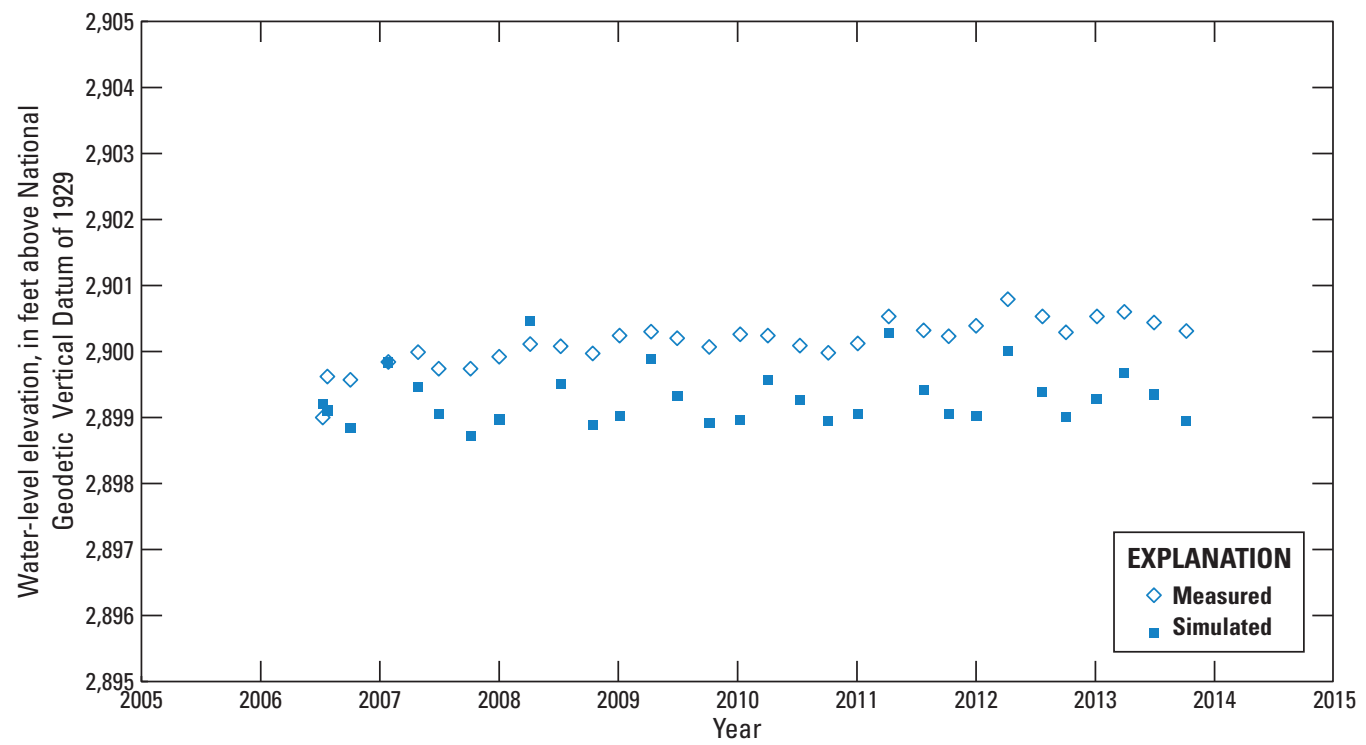

Figure 21. Measured and simulated water levels in observation well 13S/09E-03AAC3 in the upper Metolius River Basin near Camp Sherman, Oregon.

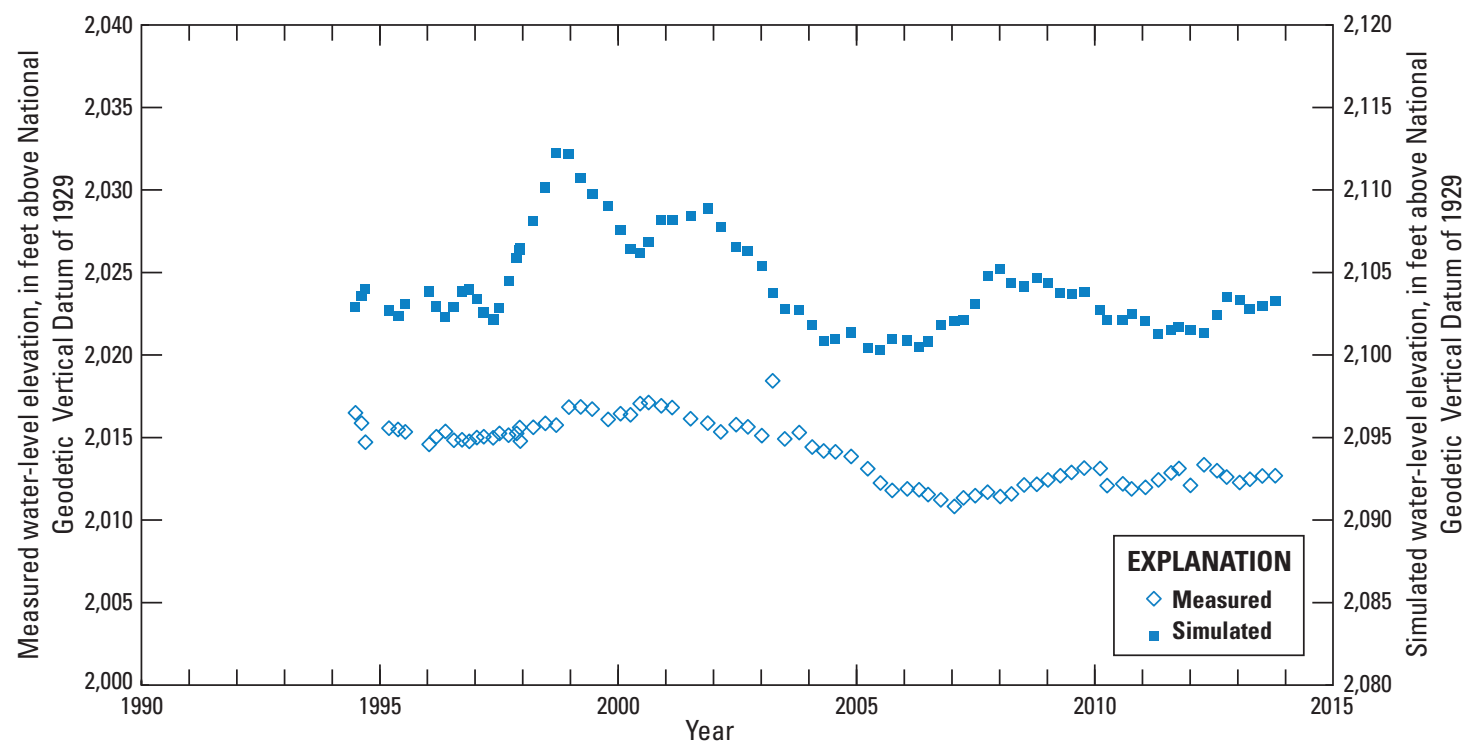

Figure 22. Measured and simulated water levels in observation well 11S/13E-24BCD east of Madras, Oregon. 


\section{Powell Buttes/Prineville Area}

The Powell Buttes area, in the northeastern part of the model, is largely represented by zone 9 (fig. 10). Water levels in monitored wells are for the most part stable in this area with some exceptions. A few wells southeast of Powell Buttes exhibit slightly rising water levels thought to be due to the filling of Prineville Reservoir which was completed in the early 1960s. In the western part of this area, northwest of Powell Buttes, post-2000 water-level declines of about $15 \mathrm{ft}$ measured in well 15S/14E-23CAD are reasonably well simulated (fig. 23A). A slight decline measured in well 15S/15E-03BA, a few miles west of Prineville, is also captured by the model (fig. 23B).
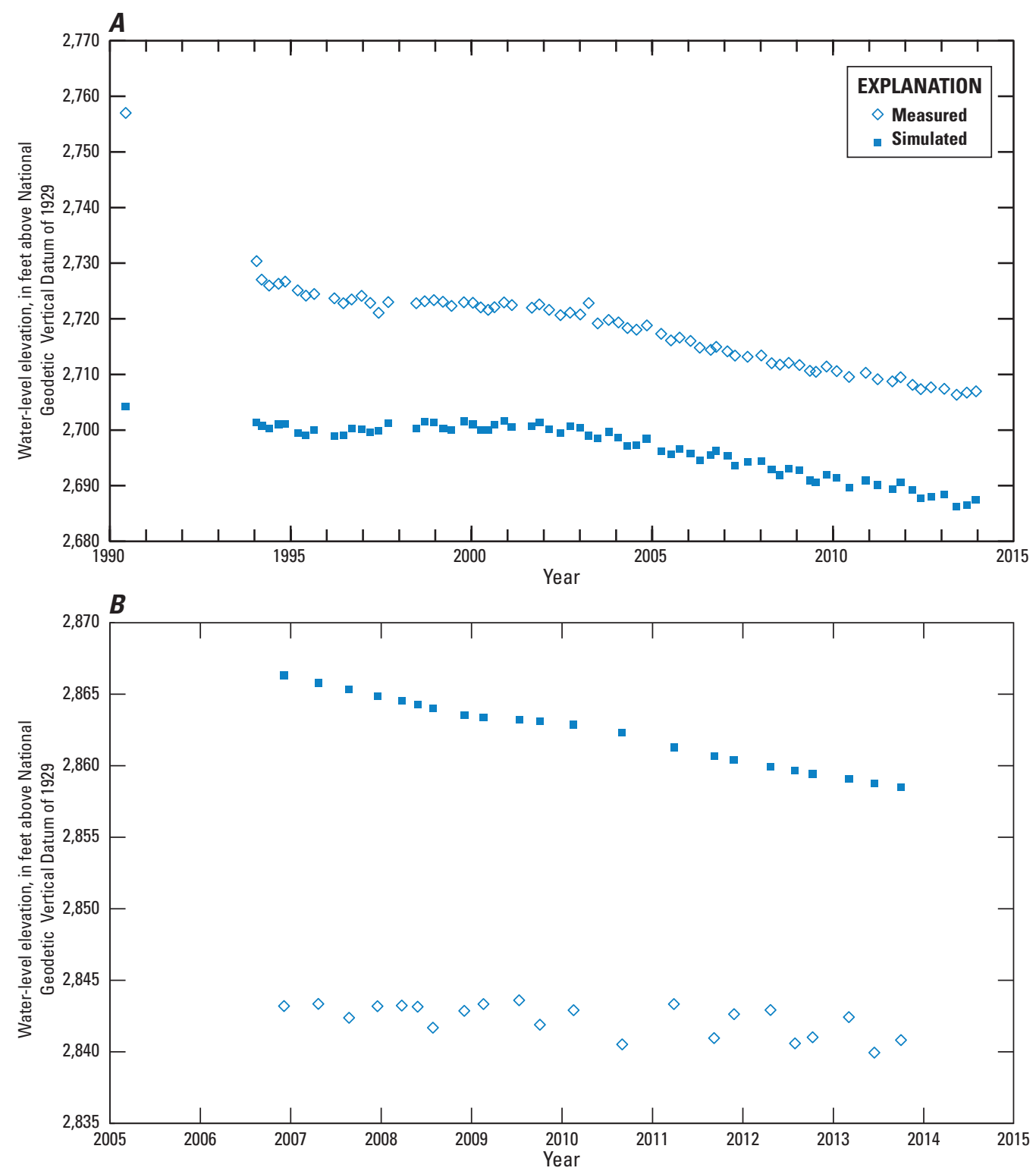

Figure 23. Measured and simulated water levels in observation wells 15S/14E-23CAD (A) and 15S/15E-03BA (B) near Powell Butte, Oregon. 


\section{Simulated Groundwater Discharge and Streamflow}

A substantial portion of the water that enters the upper Deschutes Basin as precipitation leaves as streamflow. GSFLOW simulates the major components of streamflow including the direct runoff (Hortonian flow), leakage of groundwater to the surface through springs where hydraulic head is above land surface (Dunnian flow), interflow (shallow subsurface water movement through the soil), and direct groundwater discharge to streams (which is primarily through springs in and adjacent to the streambed). In the upper Deschutes Basin, most of the streamflow is due to groundwater discharge through springs and spring complexes directly associated with streams. Many streams are entirely spring fed. Gannett and others (2003) estimate that groundwater discharge through all mechanisms accounts for about 80 percent of the streamflow of the Deschutes River near Culver, and 90 percent at Madras.

In GSFLOW, direct groundwater discharge occurs only to streams explicitly simulated in the model (fig. 7). Discharge to springs associated with small tributaries not explicitly simulated manifests as Dunnian flow, and is routed to the appropriate simulated stream according to the topographically derived cascade relations between grid cells.

The GSFLOW model was constructed and calibrated to simulate both the spatial distribution of groundwater discharge (fig. 5) and the temporal variation in streamflow. The spatial distribution was informed by streamgage data, seepage runs, analysis of stream hydrographs, and miscellaneous measurements as described in section, "Groundwater Movement to and from Streams." The temporal variation in streamflow, as well as the total volume, was informed by streamgage data and, where necessary, calculated naturalized flows described in the preceding section on "Flow Data."

The upper Deschutes Basin GSFLOW model is regional in scale and covers areas with little or no subsurface data. Because of this, conditions are generalized over large parts of the model domain. As a consequence, large streams, which tend to integrate conditions over large geographic areas, are generally simulated more accurately than small tributaries. The hydrology of small tributaries is more heavily influenced by small-scale local conditions not represented in the model. Efforts were made to achieve the best fit to streams at the full range of scales. Following are discussions of the model-wide spatial distribution of groundwater discharge to streams, and simulated streamflow at key gage locations.

\section{Spatial Distribution of Groundwater Discharge}

The overall spatial distribution and volume of simulated groundwater discharge to streams agrees with observations, especially along the main-stem streams and major tributaries (fig. 24). A direct visual comparison between the estimated gains and losses (fig. 5) and the simulated spatial gain/loss distribution (fig. 24) is difficult because estimated distributions are generalized over long stream reaches (upstream of gages or measurement locations, between gages, or between measurements points during seepage runs), and are intended to represent average conditions over time. Simulated values, in contrast, are at a cell by cell resolution at a particular point in time.

Simulations reproduce the location of gaining reaches in the upper parts of the Little Deschutes River and Crescent Creek. The relatively small downstream seepage losses, however, are not captured by the model. The small losses shown on figure 5 along the lower part of Crescent Creek are very small and within the streamflow measurement error (Gannett and others 2003). The loss shown on figure 5 along the Little Deschutes River upstream of Crescent Creek is also small and, although probably real, may not reflect average long-term conditions.

The location of simulated groundwater discharge to tributaries of Crane Prairie Reservoir (which, like Wickiup Reservoir, is simulated as part of the stream network) is also generally consistent with the spatial distribution of springs and spring-fed streams. The presence of simulated stream losses in the area of Crane Prairie reservoir agrees with known seepage at that location. The losses between Benham Falls and Bend, the volumetrically largest stream losses in the basin downstream of Wickiup Reservoir, are also simulated by the model.

The location of groundwater discharge to the upper part of Tumalo Creek (fig. 24) is consistent with recent measurements by OWRD (Rich Marvin, Oregon Water Resources Department, written commun., 2015). The locations of simulated gains along the upper reaches of Whychus Creek and Indian Ford Creek, are also consistent with earlier measurements and estimates. The gain to Whychus Creek east of McKinney Butte downstream of the confluence with Indian Ford Creek reflects known discharge from springs at that location (Hackett, 2011).

The spatial distribution of gains in the upper Metolius River drainage, which account for a substantial part of the discharge from the entire upper Deschutes Basin, is consistent with earlier estimates of Gannett and others (2001) as well as recent streamgage data by OWRD (Oregon Water Resources Department, 2017). The location of simulated gains along the main stem of the Deschutes River between Lower Bridge and Lake Billy Chinook, as well as the lowermost part of Whychus Creek, are consistent with field measurements. The overall magnitude and location of simulated groundwater discharge to the lower Crooked River are consistent with seepage runs as well as gage data. The simulation of groundwater discharge to Lake Billy Chinook is consistent with net groundwater discharge estimates derived from a mass balance done by Gannett and others (2001). 


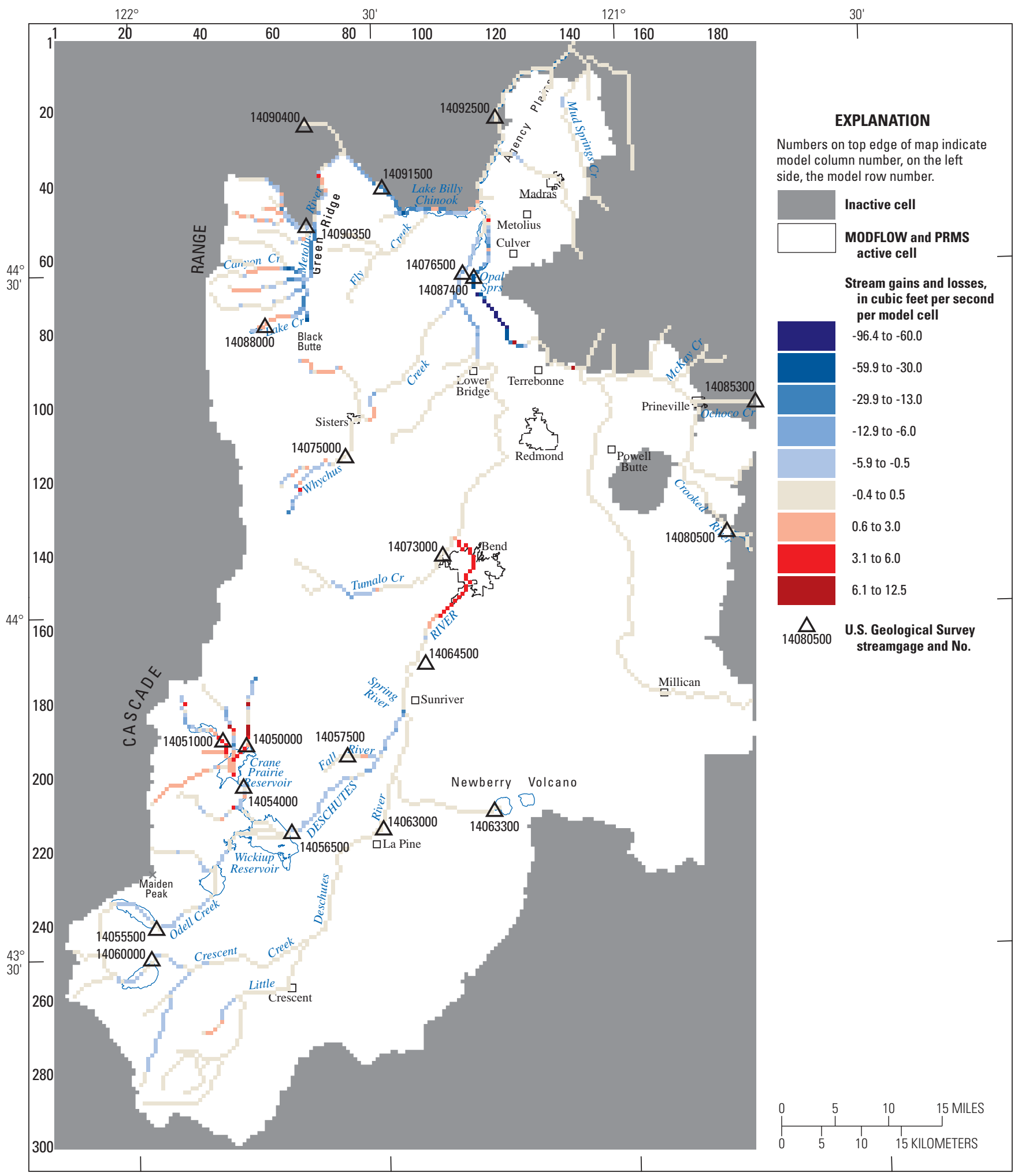

Coordinate reference system: Universal Transverse Mercator Zone 10 North, horizontal datum is North American Datum of 1983.

Figure 24. Spatial distribution of simulated groundwater discharge to streams, December 2013, and locations of selected streamgage locations, upper Deschutes Basin, Oregon. Per MODFLOW convention, negative values indicate groundwater discharge to streams (gaining reaches) and positive values indicate seepage from streams to the groundwater system (losing reaches). 


\section{Simulated Streamflow}

The temporal variations in groundwater discharge, along with the other components of streamflow, were evaluated using data from streamgages and the previously described naturalized flows at gage locations (fig. 24). Comparisons in this discussion begin in 1985 to reduce effects of model spin-up and end according to the period of record for the associated measurements. Where comparisons between simulated and naturalized flows are made in this section, the comparisons are limited to the period from 1985 to 2008, to match the period of record available for the naturalized flows.

The naturalized flows at the Deschutes River at Madras (USGS streamgage 14092500) and the Crooked River below Opal Springs (USGS streamgage 14087400) include flows originating outside the model domain in the upper parts of the Crooked River drainage. Most of the flow entering the model domain at the boundary is measured at two streamgage locations: the Crooked River near Prineville (USGS streamgage 14080500) and Ochoco Creek below Ochoco Reservoir (USGS streamgage 14085300). Catchments upstream of these boundary gage locations drain low-permeability terrain and have relatively flashy, runoff-dominated behavior. Naturalized flows have been calculated for these boundary gage locations to remove the effects of diversions and reservoir operations (Bonneville Power Administration, 2017). To aid in comparison between the simulated streamflows and the naturalized flows, the naturalized flow estimates for Ochoco Creek and Crooked
River near Prineville are added to the simulated flows of the Crooked River below Opal Springs and the Deschutes River near Madras.

In addition to having the effects of storage and diversion removed, the naturalized flows also have effects of canal leakage and groundwater pumping removed (Bureau of Reclamation, 2017). Like the naturalized flows, the model does not simulate the effects of storage and diversions. Canal leakage and pumping, however, are included in simulations. These stresses are necessary in the model to fit measured heads. Toward the end of the calibration period, these additional stresses combined (which are dominated by canal leakage) should result in the simulated mean annual discharge at Madras to be roughly $350 \mathrm{ft}^{3} / \mathrm{s}$ larger than the calculated naturalized flows, assuming the naturalized flows are exact and the model fit is perfect.

Daily flows of the Deschutes River near Madras (USGS streamgage 14092500) match the naturalized flows reasonably well (fig. 25). Mean simulated flow at Madras from 1985 to 2008 is about $247 \mathrm{ft}^{3} / \mathrm{s}$ larger than the mean naturalized flow of 5,342 $\mathrm{ft}^{3} / \mathrm{s}$ during the same period (table 5). The $247 \mathrm{ft}^{3} / \mathrm{s}$ difference at Madras is not quite as large as the expected $350 \mathrm{ft}^{3} / \mathrm{s}$ difference previously described, but is reasonably close. In addition to overall flows, the monthly distribution of flow and the interannual variations also match well (fig. 26). A comparison of mean monthly simulated and naturalized flows (fig. 26A) shows that peak timing of flow is consistent, and that much of the overall difference in flow occurs during the winter and spring months.

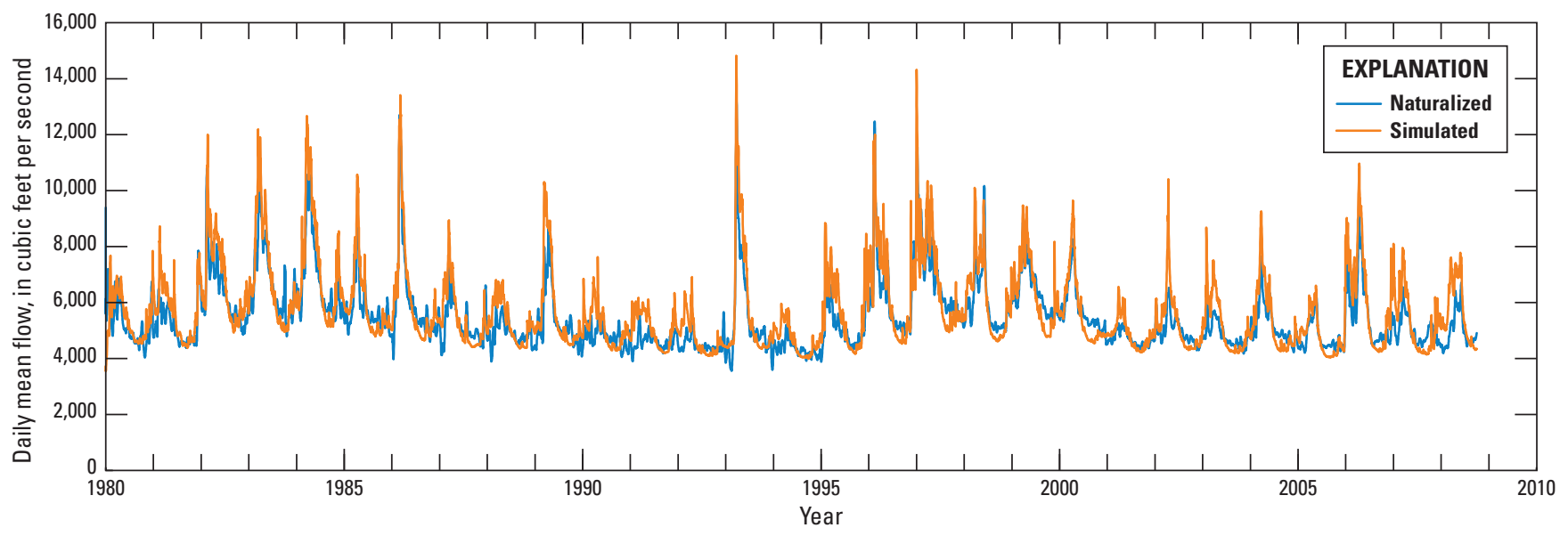

Figure 25. Simulated and naturalized daily mean flows of the Deschutes River near Madras, Oregon (USGS streamgage 14092500). Naturalized daily mean flows are smoothed using a 10-day running average. 

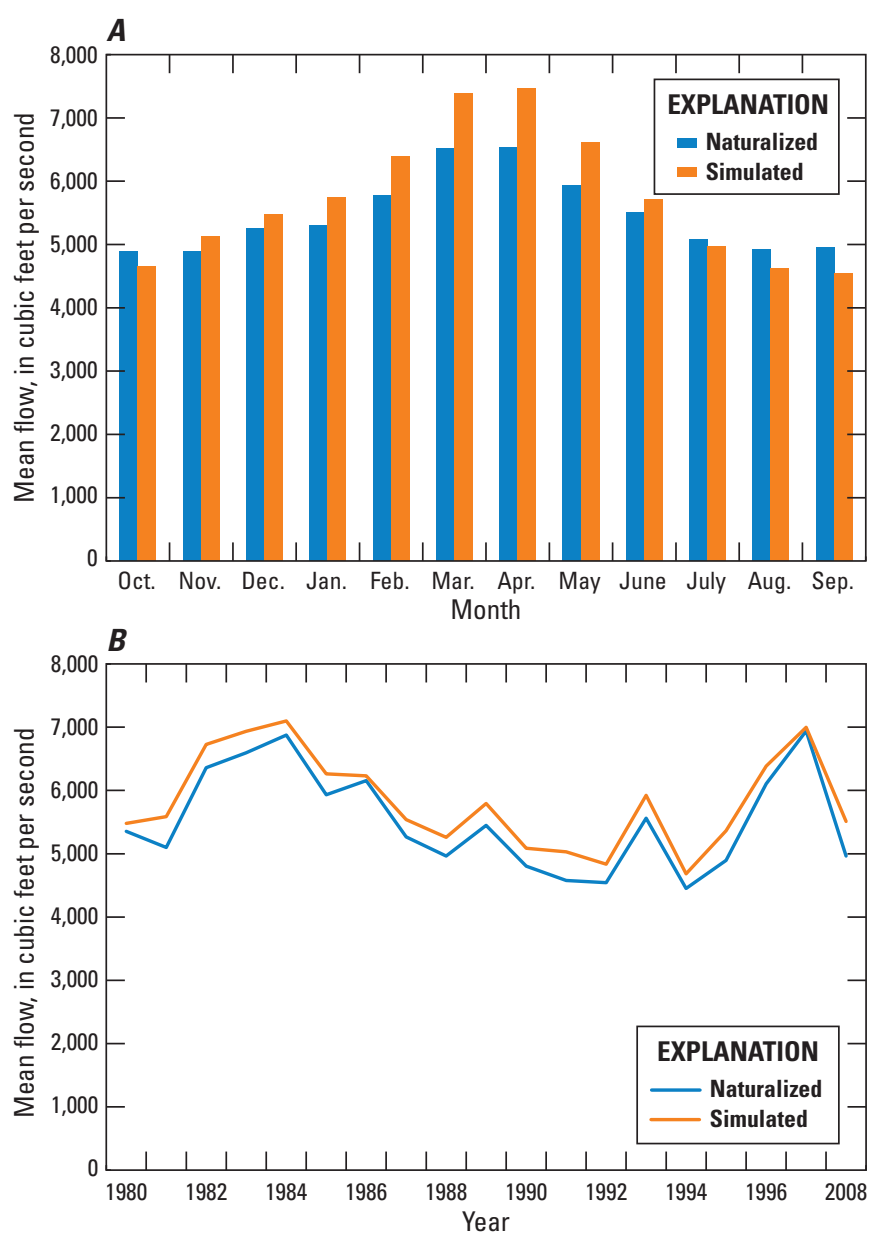

Figure 26. Simulated and naturalized $(A)$ mean-monthly flows and $(B)$ mean-annual flows of the Deschutes River near Madras, Oregon (USGS streamgages 14092500).

Table 5. Simulated and observed (gaged or naturalized) flows at selected USGS streamgages in the upper Deschutes Basin, Oregon.

[Period of comparision: Period of comparison starts at 1985 to reduce effects of model spin up. Period ending year dictated by period of record for observed data. O bservation type: gaged, streamflows measured at a gage; naturalized, synthetic streamflows representing naturalized conditions. Difference and Difference (percent of observed): Positive values indicate simulated value greater than observed, negative values indicate simulated values less than observed. A bbreviation: $\mathrm{ft}^{3} / \mathrm{s}$, cubic foot per second]

\begin{tabular}{|c|c|c|c|c|c|c|c|}
\hline USGS streamgage name & $\begin{array}{c}\text { Streamgage } \\
\text { No. }\end{array}$ & $\begin{array}{c}\text { Period of } \\
\text { comparison }\end{array}$ & $\begin{array}{c}\text { Observation } \\
\text { type }\end{array}$ & $\begin{array}{c}\text { Mean } \\
\text { observed } \\
\text { flow } \\
\left(\mathrm{ft}^{3} / \mathbf{s}\right)\end{array}$ & $\begin{array}{c}\text { Mean } \\
\text { simulated } \\
\text { flow } \\
\left(\mathrm{ft}^{3} / \mathbf{s}\right)\end{array}$ & $\begin{array}{c}\text { Difference } \\
\left(\mathrm{ft}^{3} / \mathbf{s}\right)\end{array}$ & $\begin{array}{l}\text { Difference } \\
\text { (percent of } \\
\text { observed) }\end{array}$ \\
\hline Cultus River & 14050500 & 1985-2013 & Gaged & 57.2 & 42.6 & -14.6 & -25.5 \\
\hline Deschutes River below Crane Prairie Reservoir & 14054000 & 1985-2008 & Naturalized & 288 & 458 & 170 & 59.0 \\
\hline Odell Creek near La Pine & 14055600 & 1985-2011 & Gaged & 113 & 125 & 12.2 & 10.8 \\
\hline Little Deschutes River near La Pine & 14063000 & 1985-2013 & Gaged & 172 & 230 & 58.2 & 33.8 \\
\hline Deschutes River near Benham Falls & 14064500 & 1985-2008 & Naturalized & 1,380 & 1,341 & -39.3 & -2.8 \\
\hline Deschutes River below Bend & 14070500 & 1985-2008 & Naturalized & 1,302 & 1,272 & -30.1 & -2.3 \\
\hline Tumalo Creek below Tumalo Feed Canal & 14073001 & 1985-2008 & Naturalized & 97.5 & 51.4 & -46.1 & -47.2 \\
\hline Whychus Creek near Sisters & 14075000 & 1985-2013 & Gaged & 101 & 128 & 27.1 & 26.9 \\
\hline Deschutes River near Culver & 14076500 & 1985-2008 & Naturalized & 1,742 & 1,735 & -6.8 & -0.4 \\
\hline
\end{tabular}


As with the flows at Madras, a comparison of daily simulated and naturalized flows of the Metolius River shows that the magnitude, and seasonal and interannual variations in flow match reasonably well (fig. 27). Mean simulated flow of the Metolius River at Grandview (USGS streamgage 14091500) is $107 \mathrm{ft}^{3} / \mathrm{s}$ larger than the gaged flow of $1,516 \mathrm{ft}^{3} / \mathrm{s}$ during the period of comparison, a difference of 7 percent (table 5). A comparison of mean monthly flows for the simulation period (fig. 28A) shows that the amplitude of the simulated seasonal variation is slightly larger than measured. Interannual variations are simulated well (fig. 28B). Simulated flows at the Metolius River are heavily influenced by the constant $994 \mathrm{ft}^{3} / \mathrm{s}$ boundary flow specified in the northwestern part of the model. The importance of the boundary flow is highlighted by the fact that although the Metolius River near Grandview accounts for about 28 percent of the flow at Madras, it encompasses only 4 percent of the contributing drainage area.

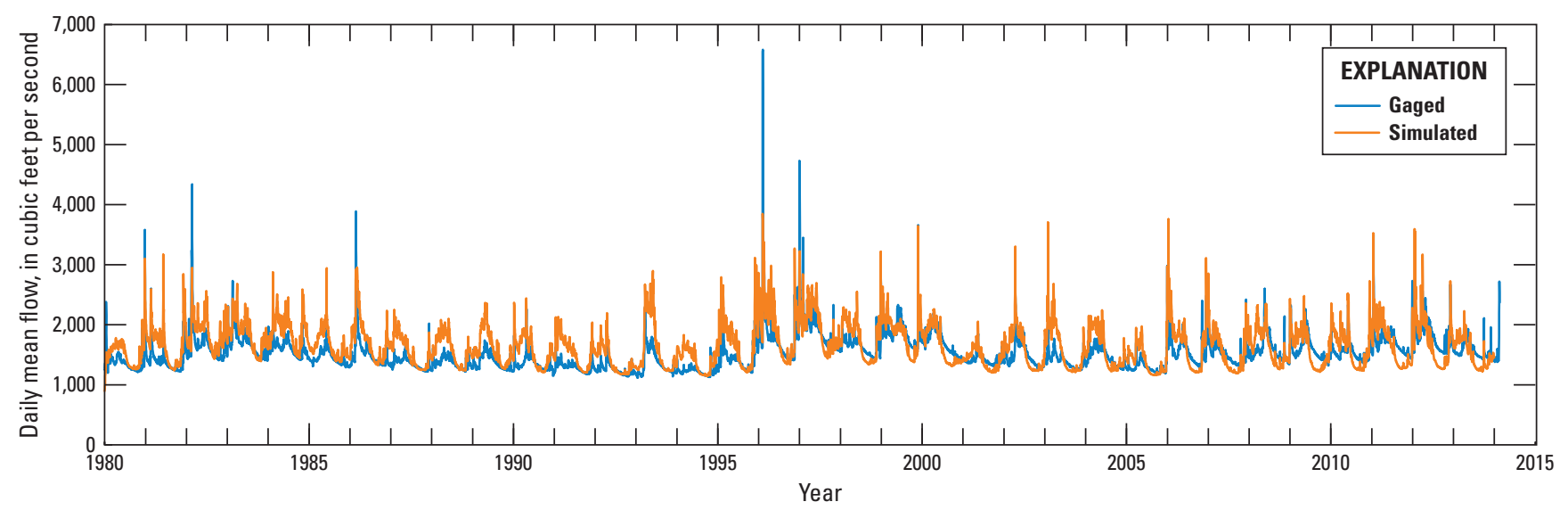

Figure 27. Simulated and gaged daily mean flows of the Metolius River near Grandview, Oregon (USGS streamgage 14091500). Naturalized daily mean flows are smoothed using a 10-day running average.
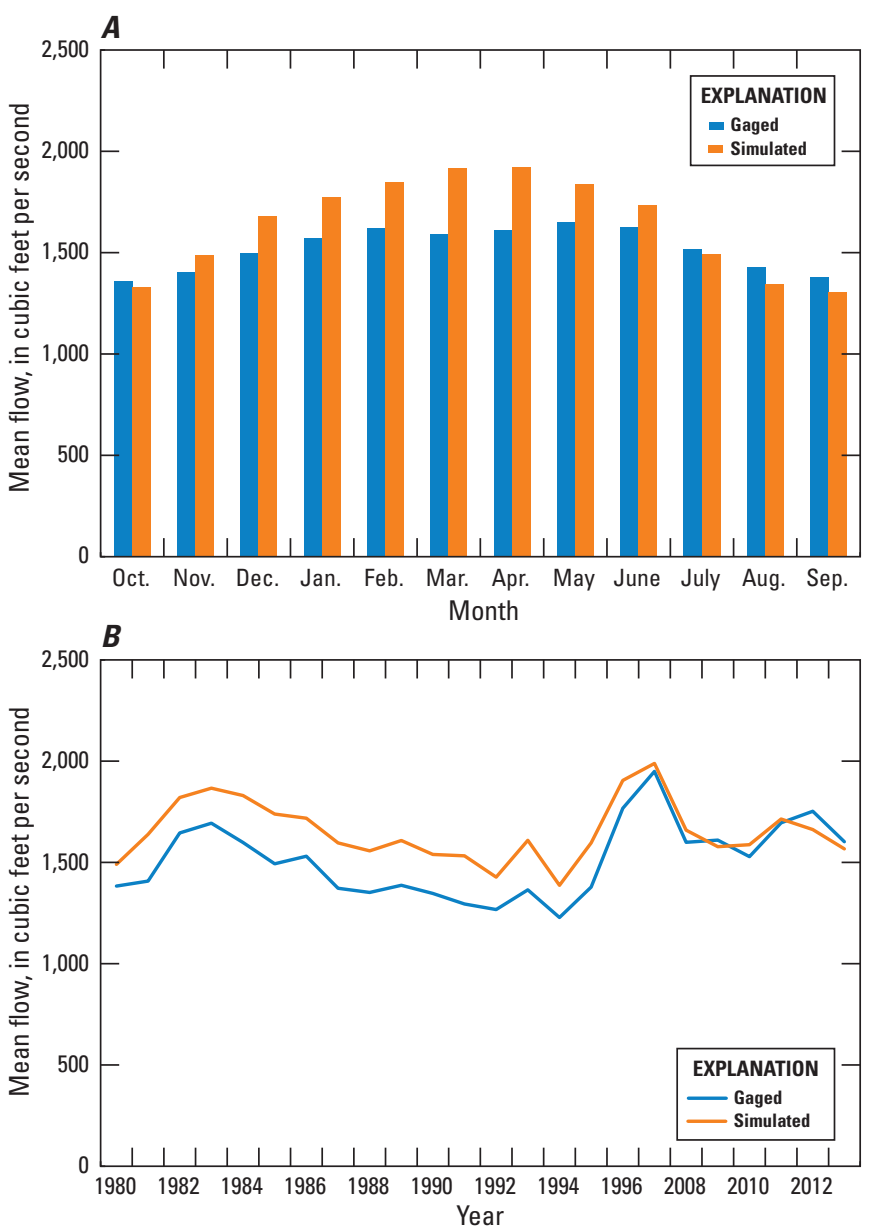

Figure 28. Simulated and gaged $(A)$ mean-monthly flows and $(B)$ mean-annual flows of the Metolius River near Grandview, Oregon (USGS streamgage 14091500). 
The Crooked River below Opal Springs (USGS streamgage 14087400) accounts for about 29 percent of the discharge of the Deschutes River near Madras. Most of the flow of the Crooked River at this location originates as groundwater discharge through springs in the streambed or canyon wall along the reach extending about $10 \mathrm{mi}$ upstream of the gage. Simulated daily flows are very constant with little seasonal variation (fig. 29), which is consistent with the behavior of groundwater discharge measured using gages bracketing the gaining reach. When the naturalized flows from the Crooked River near Prineville and Ochoco Creek below Ochoco Dam (the boundary gage locations) are added to the simulated flows, the resulting total matches well the naturalized flows of the Crooked River below Opal Springs (fig. 29). The mean of the sum of the simulated and boundary flows exceeds the naturalized flow at Opal Springs by about $46 \mathrm{ft}^{3} / \mathrm{s}$; about 3 percent of the naturalized flow (table 5).

Sceva (1968) and Gannett and others (2001) concluded from analysis of historical gage and canal-loss data that much of the water lost through canal leakage returns to the Crooked River upstream of the Opal Springs gage. Because the effects of canal leakage are removed from the naturalized flows, the simulated baseflow should exceed the naturalized flow by an additional $200-300 \mathrm{ft}^{3} / \mathrm{s}$. The fit between naturalized and simulated monthly and annual mean flows is shown in figure 30 .

About one-third of the flow of the Deschutes River near Madras passes the gage at the Deschutes River near Culver (USGS streamgage 14076500) upstream of Lake Billy Chinook. A comparison of simulated and naturalized flows (fig. 31 ) shows that the model simulates the overall flow volumes (table 5) and interannual variations reasonably well. The seasonal peaks, however, are not as well fit as with the Metolius and Crooked Rivers, and the Deschutes River near Madras. The mean simulated flow rate, $1,735 \mathrm{ft}^{3} / \mathrm{s}$, is about $7 \mathrm{ft}^{3} / \mathrm{s}$ less than the naturalized flow of $1,742 \mathrm{ft}^{3} / \mathrm{s}$, a difference of about -0.4 percent.

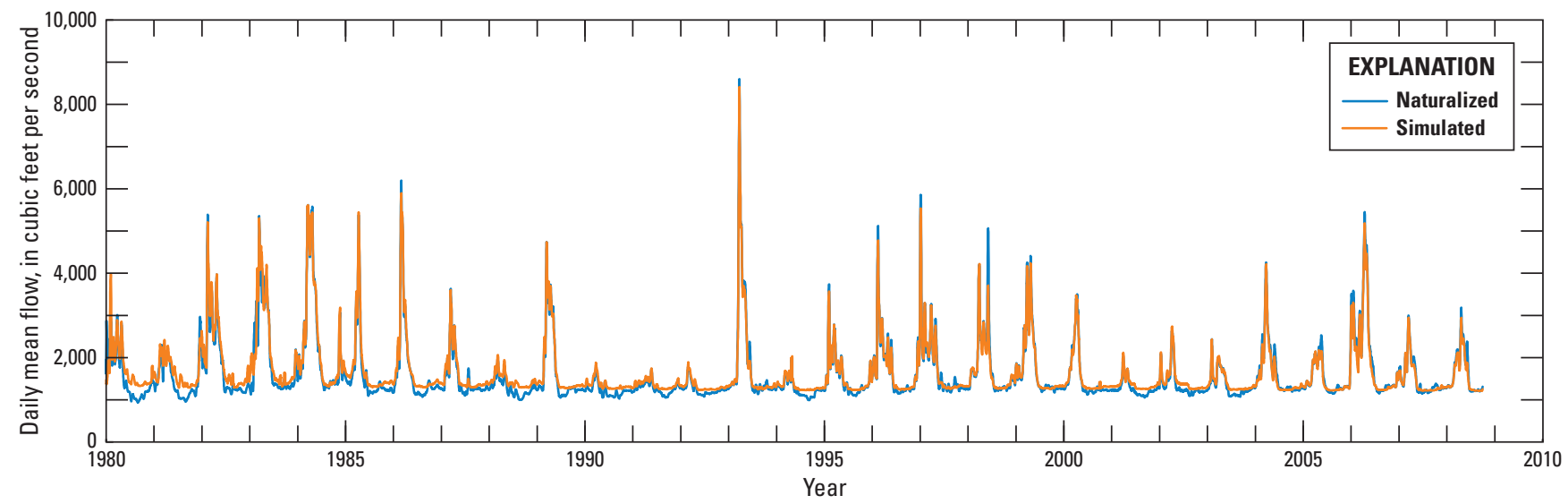

Figure 29. Simulated and naturalized daily mean flows of the Crooked River below 0pal Springs, Oregon (USGS streamgage 14087400). Naturalized daily mean flows are smoothed using a 10-day running average. 

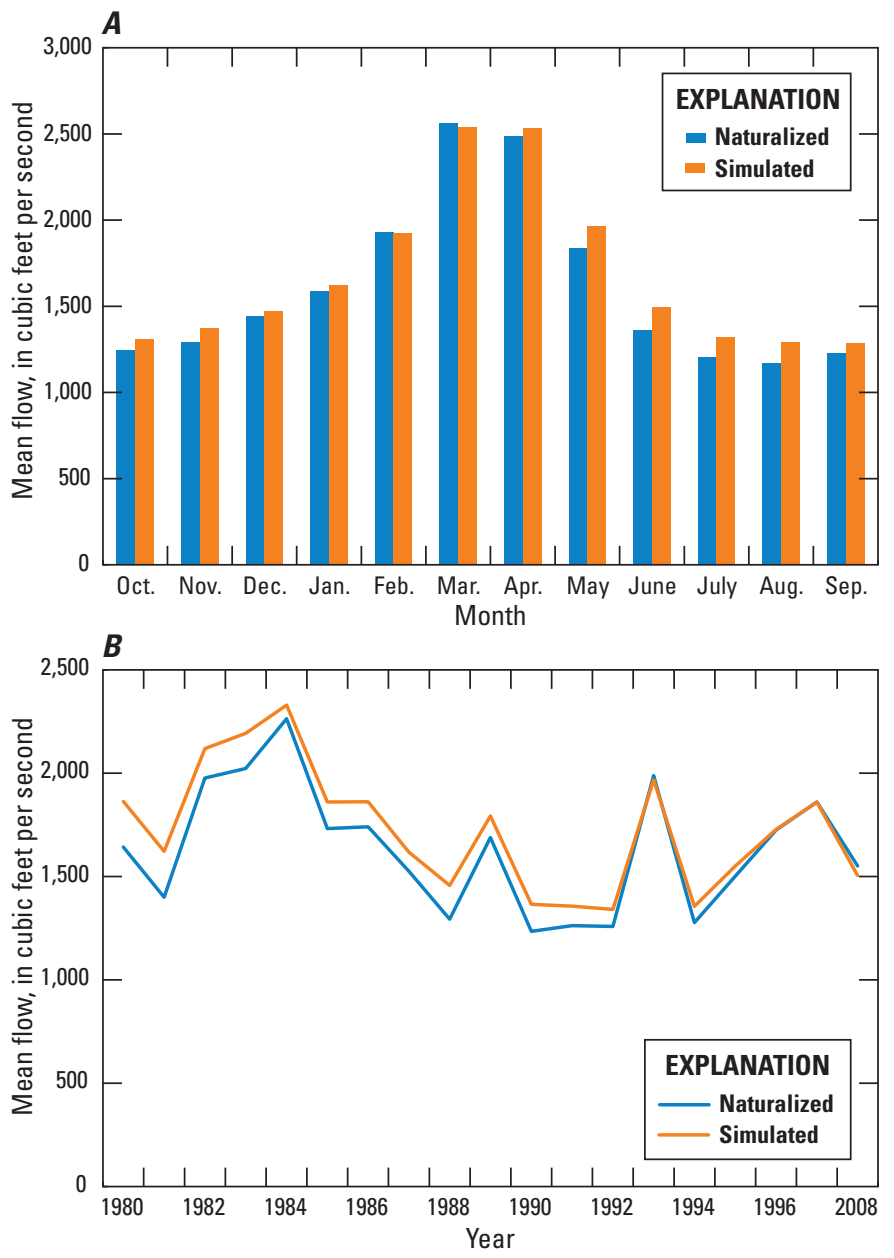

Figure 30. Simulated and naturalized $(A)$ mean-monthly and (B) mean-annual flows of the Crooked River below Opal Springs, Oregon (USGS streamgage 14087400).

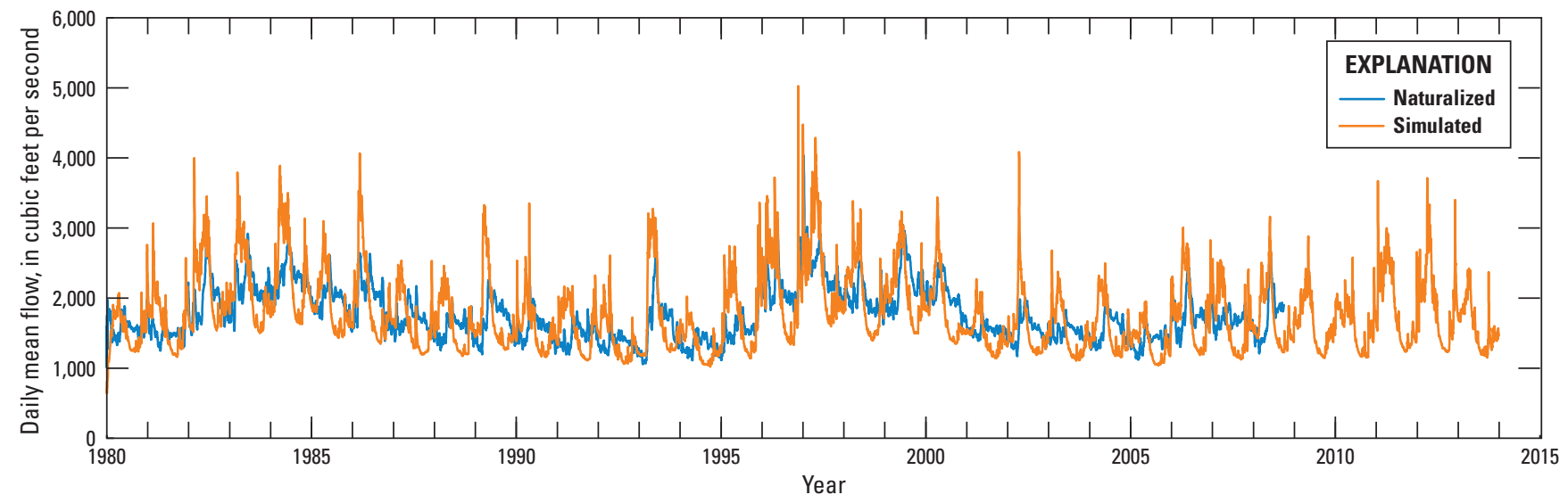

Figure 31. Simulated and naturalized daily mean flows of the Deschutes River near Culver, Oregon (USGS streamgage 14076500). Naturalized daily mean flows are smoothed using a 10-day running average. 
A comparison of mean monthly simulated and naturalized flows (fig. 32A) shows that simulated seasonal variations are larger than those of the naturalized flows and that simulated flows generally peak in April, while the naturalized flows peak in the May/June period. There is good fit between simulated and naturalized interannual variations in annual mean flows (fig. 32B). The model fit here reflects the attempt to balance overall budgets, flows at tributaries, and hydraulic heads. The upper Deschutes Basin upstream of the gage near Culver comprises about 54 percent of the model domain, spans large meteorological
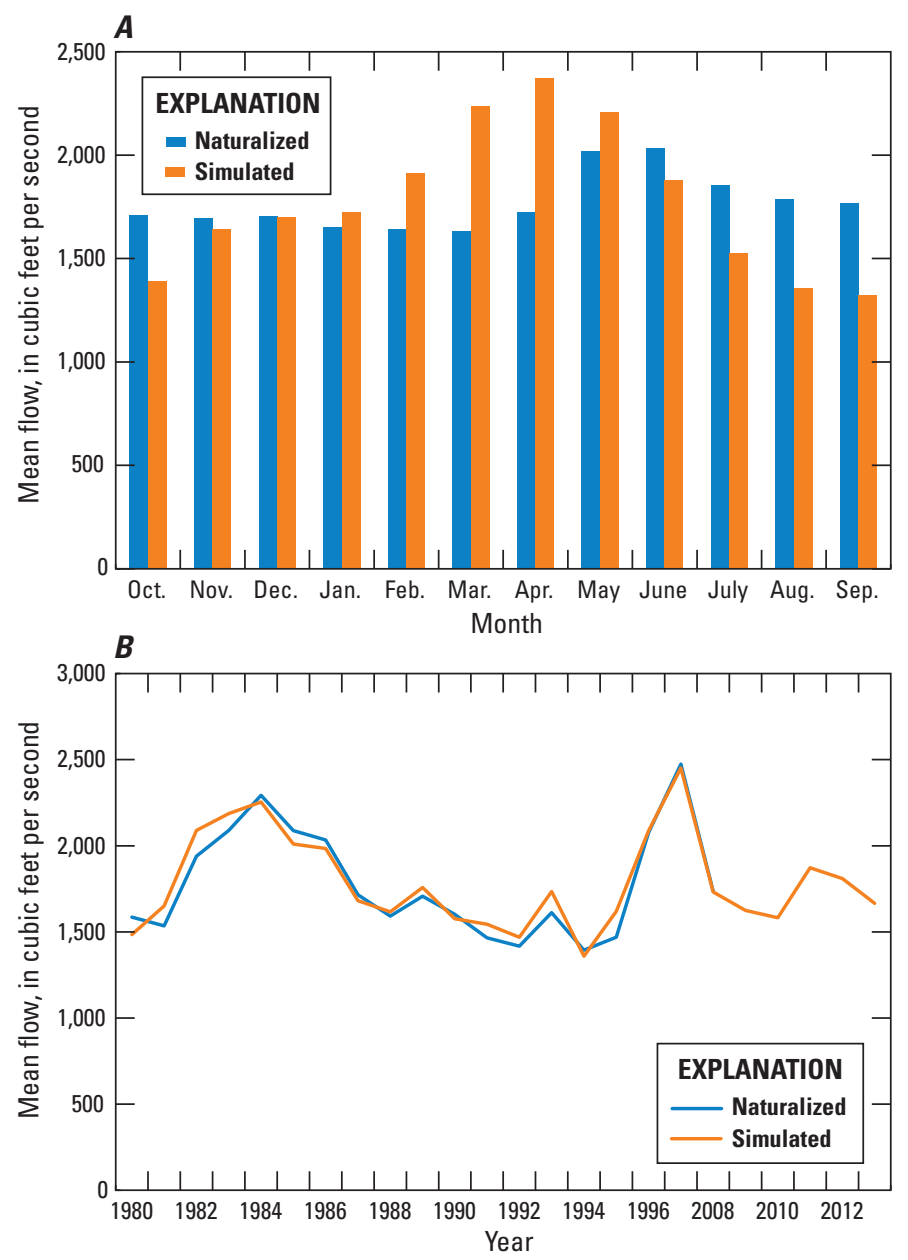

gradients and includes contributions from dozens of tributaries with diverse geology and hydrology. Moreover, the naturalized flows to which simulated values are being compared include corrections made for storage changes, evaporation, and seepage from multiple reservoirs, diversions to dozens of canals, artificial recharge from canal leakage, and groundwater pumping. Although the naturalized flows are corrected for reservoir storage, bank storage, which is not well understood, is not considered. The large complexity and multiple sources of error in both the simulated flows and the naturalized flows affect the model fit at this site.

Figure 32. Simulated and naturalized $(A)$ mean-monthly flows and $(B)$ mean-annual flows of the Deschutes River near Culver, Oregon (USGS streamgage 14076500). 
Whychus Creek is tributary to the Deschutes River upstream of Culver, and an important source of irrigation water. Gaged flows are available for Whychus Creek near Sisters (USGS streamgage 14075000). Simulated mean flow is $27 \mathrm{ft}^{3} / \mathrm{s}$ larger than the mean gaged flow of $101 \mathrm{ft}^{3} / \mathrm{s}$; a difference of about 27 percent (table 5). Simulated monthly mean flows (fig. 33A) show smaller variations than the gaged flows, and simulated annual mean flows (fig. 33B) show smaller interannual variations. Simulated flows generally peak in May, a month earlier than the gaged flows. Whychus is one of two simulated streams draining the Three Sisters area, the other being Tumalo Creek below Tumalo Feed Canal (USGS streamgage 14073001). Simulated flows of Tumalo Creek also under represent seasonal and interannual variations. Simulated mean flow of Tumalo Creek, $51 \mathrm{ft}^{3} / \mathrm{s}$, is $46 \mathrm{ft}^{3} / \mathrm{s}$ (47 percent)
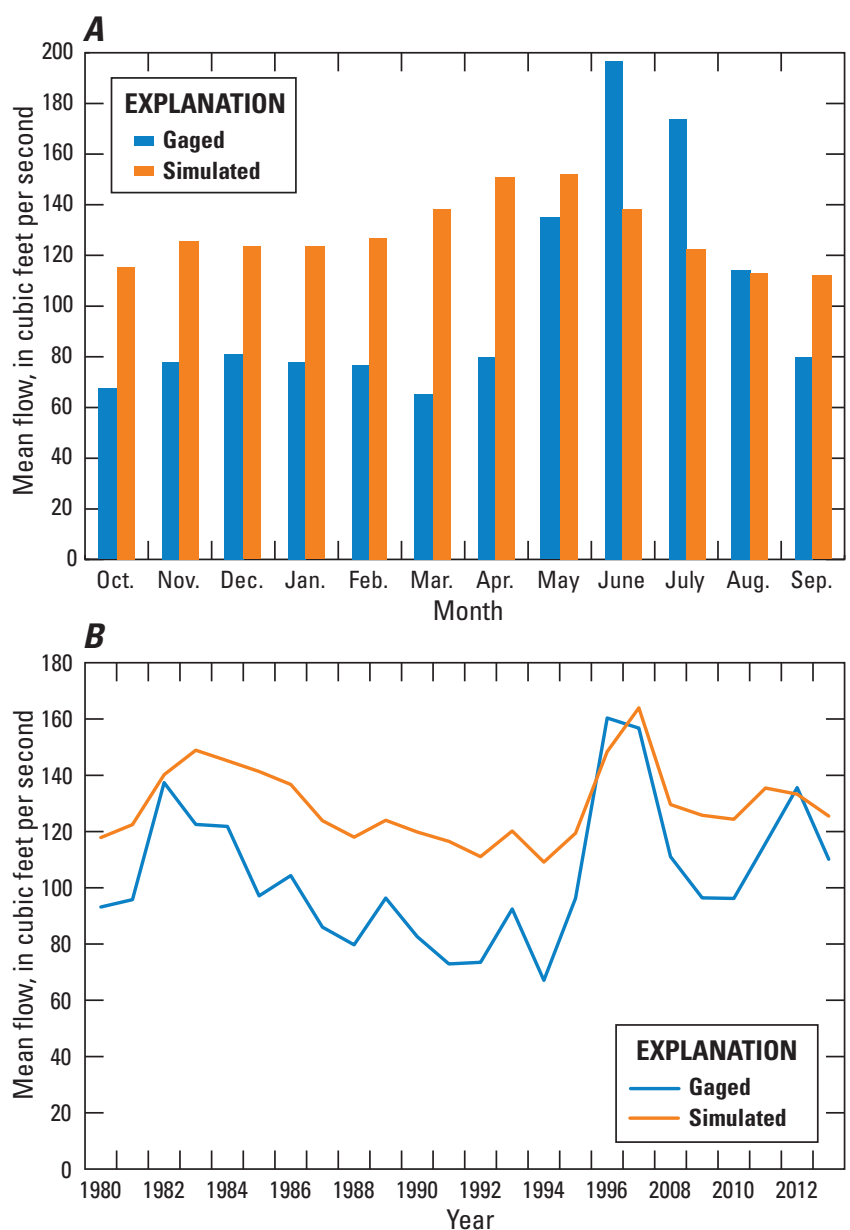

smaller than the mean naturalized flow of $97 \mathrm{ft}^{3} / \mathrm{s}$ table 5 . The Three Sisters area has the largest precipitation in the basin and is the locus of much of the groundwater recharge. Most of this water moves to other subbasins, and a relatively small fraction discharges to Whychus and Tumalo Creeks. The simple geologic zonation made it difficult to match hydrographs of Whychus and Tumalo Creeks while at the same time fit heads, head fluctuations, and groundwater flow to adjacent regions.

Discharge of the Deschutes River near Benham Falls (USGS streamgage 14064500), which drains about 35 percent of the model domain, accounts for about 26 percent of the flow at Madras. The mean simulated flow at Benham Falls, $1,341 \mathrm{ft}^{3} / \mathrm{s}$, is within about 3 percent of the mean naturalized flow of $1,380 \mathrm{ft}^{3} / \mathrm{s}$ during the period of comparison (table 5).

Figure 33. Simulated and gaged $(A)$ mean-monthly flows and (B) mean-annual flows of Whychus Creek near Sisters, Oregon (USGS streamgage 14075000). 
The interannual variations are also well simulated at this location (fig. 34A). Like the simulated hydrograph downstream at Culver, monthly mean flows at Benham Falls (fig. 34B) tend to show larger seasonal variation than the naturalized flows and peak in April, a month earlier than the naturalized flows. Historical monthly mean flow data from water years 1906-12 (Henshaw and others, 1914), prior to construction of Wickiup and Crane Prairie Reservoirs (Johnson and others, 1985) shows a May peak, similar timing to the naturalized flows. The pre-reservoir data show seasonal variations (based on mean monthly values) of about $467 \mathrm{ft}^{3} / \mathrm{s}$; larger than the $296 \mathrm{ft}^{3} / \mathrm{s}$ variation of the naturalized flows, but smaller than simulated $871 \mathrm{ft}^{3} / \mathrm{s}$ variation.

Mean simulated flow of the Deschutes River below Wickiup reservoir (USGS streamgage 14056500) is about
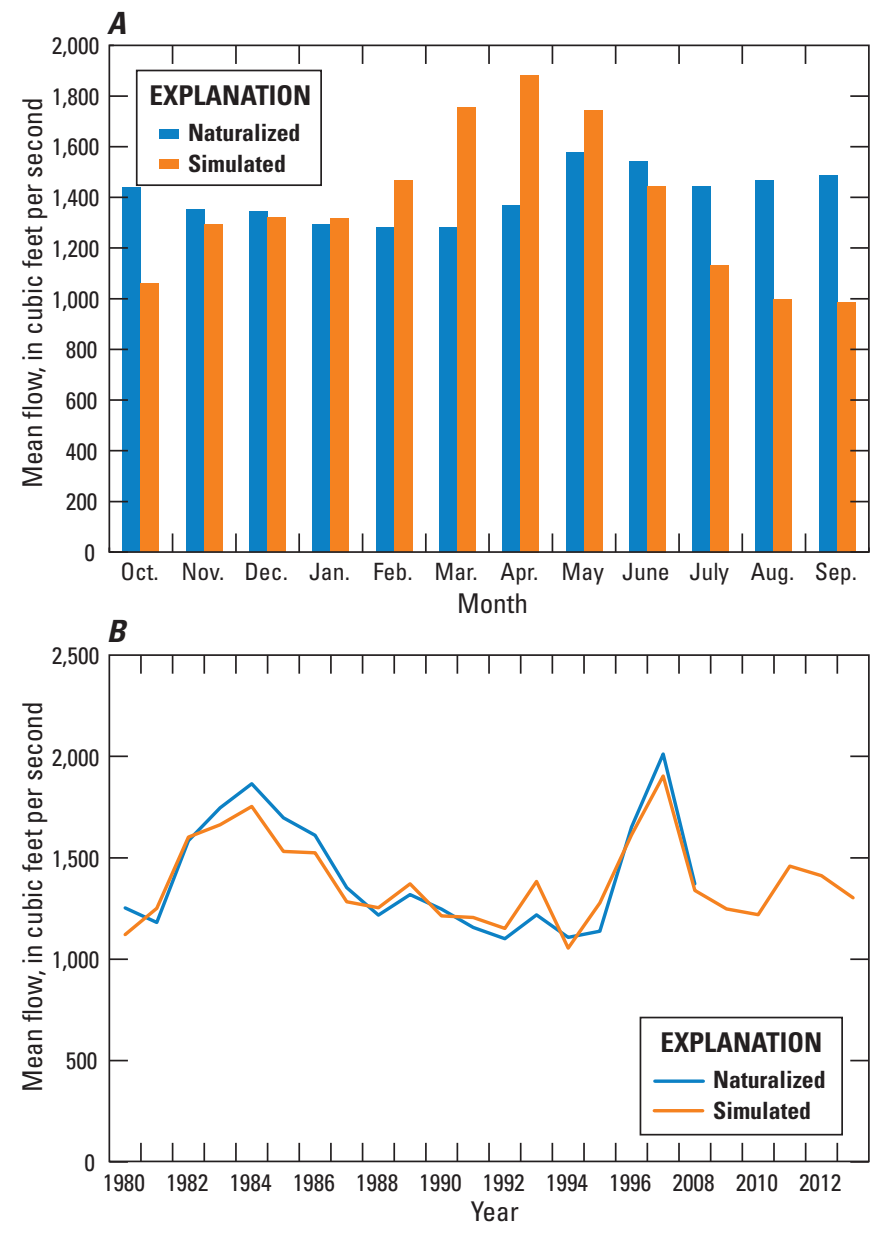

$865 \mathrm{ft}^{3} / \mathrm{s}, 12$ percent larger than the mean naturalized flow of $772 \mathrm{ft}^{3} / \mathrm{s}$ during the period of comparison (table 5). Simulated interannual variations at this location match the naturalized variations well (fig. 35).

The Little Deschutes River near La Pine (USGS streamgage 14063000) drains 11 percent of the Deschutes Basin upstream of the gage at Madras but accounts only for about 3 percent of the flow (using naturalized flow numbers). This is partly because it drains an arid part of the basin, but it is also likely that water leaves the subbasin as groundwater. Mean simulated flow of the Little Deschutes River is $230 \mathrm{ft}^{3} / \mathrm{s}$, which is about $58 \mathrm{ft}^{3} / \mathrm{s}$ (about 34 percent) larger than the mean naturalized flow of $172 \mathrm{ft}^{3} / \mathrm{s}$ (table 5). Simulated interannual and seasonal variations are smaller than observed in the naturalized flows (fig. 36).

Figure 34. Simulated and naturalized $(A)$ mean-monthly flows and $(B)$ mean-annual flows of the Deschutes River near Benham Falls, Oregon (USGS streamgage 14064500). 

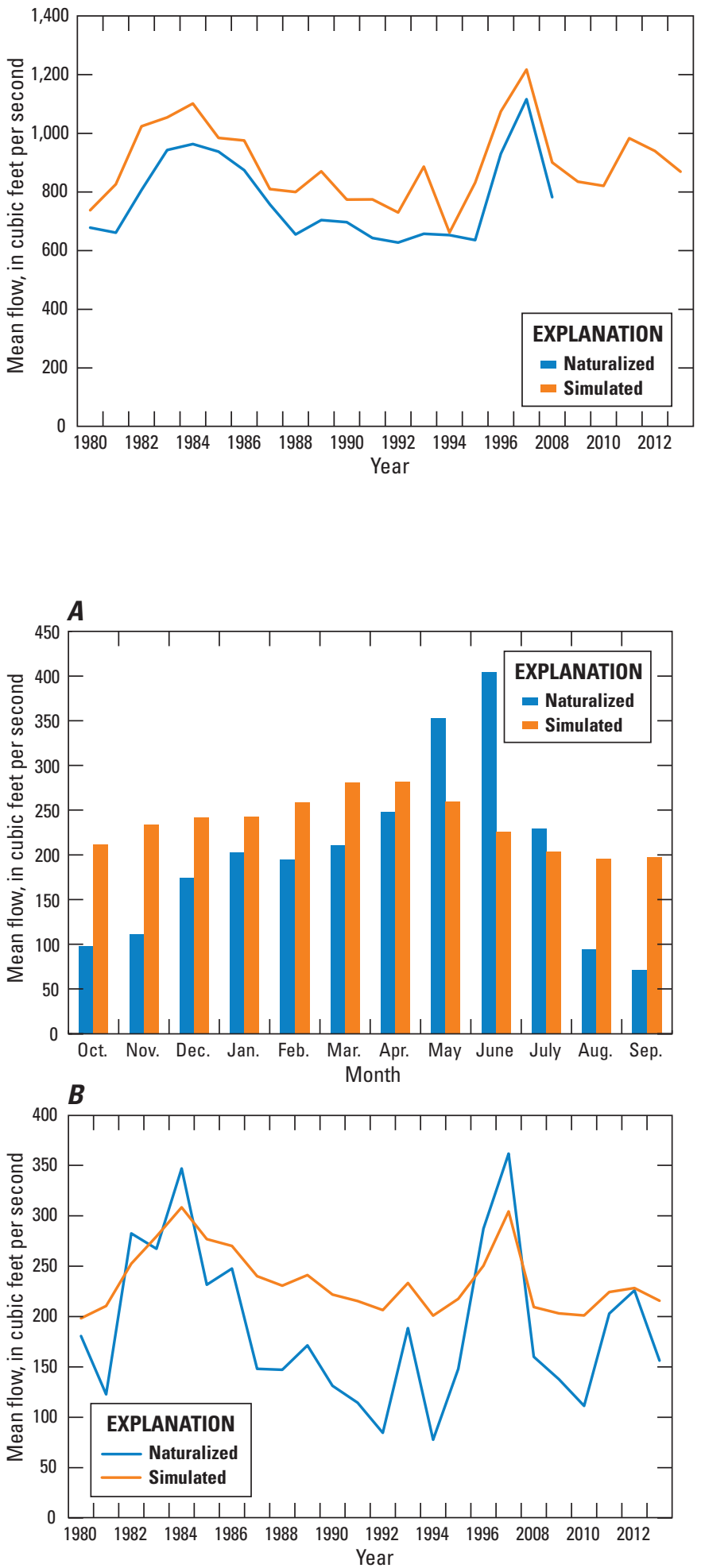

Figure 35. Simulated and naturalized mean-annual flows of the Deschutes River below Wickiup Reservoir, Oregon (USGS streamgage 14056500).
Figure 36. Simulated and naturalized $(A)$ mean-monthly flows and $(B)$ mean-annual flows of the Little Deschutes River near La Pine, Oregon (USGS streamgage 14056500). 
Simulated flows match gage data reasonably well at Odell Creek near La Pine (14055600; period of record 1980-2011). Mean simulated flow is $125 \mathrm{ft}^{3} / \mathrm{s}$, compared to a mean of $113 \mathrm{ft}^{3} / \mathrm{s}$ calculated from gage data. Simulated mean monthly
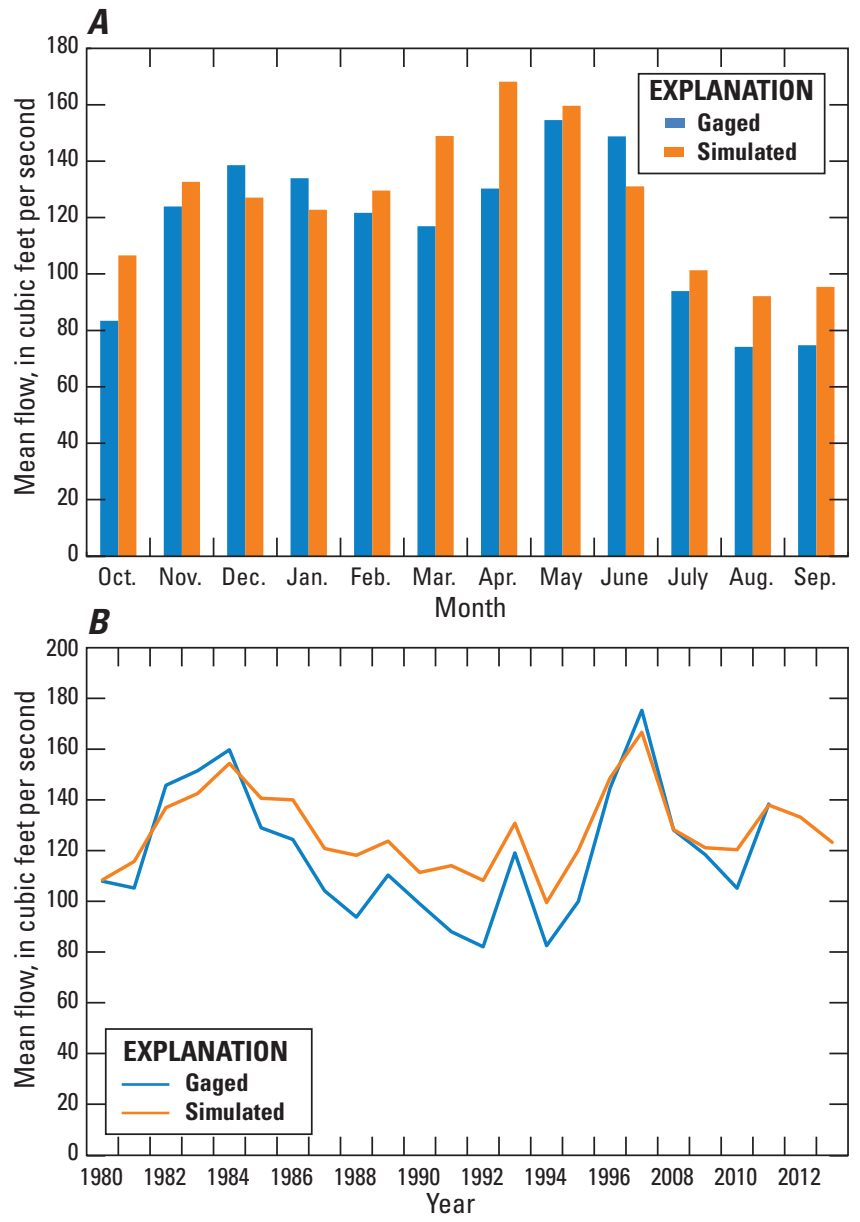

flows capture the double peak observed in the gage data, indicating both a winter storm peak and a spring snowmelt peak (fig. 37A). Simulated variations in annual mean flows match observed variations reasonably well (fig. 37B).

Figure 37. Simulated and gaged $(A)$ mean-monthly flows and $(B)$ mean-annual flows of Odell Creek near La Pine (USGS streamgage 14055600, period of record 1980-2011). 


\section{Simulated Hydrologic Budget}

The simulated hydrologic budget shows that precipitation, evapotranspiration, and streamflow are the largest components (fig. 38). Interbasin flow into the Metolius drainage (not shown on fig. 38) is also a large component, accounting for about 9 percent of the total inflow. Basin wide, groundwater pumping is a small fraction of the hydrologic budget (too small to show on fig. 38), but can be a major component at local scales, particularly in the arid basin interior.

In this model, canal leakage, which accounts for 3.6 percent of the total inflow, is introduced as a specified flow and added to the basin-wide budget. Canal leakage is actually supplied by surface-water diversions that reduce streamflow, and does not represent a net increase of the basin-wide budget. Diversions were not simulated, however, to better simulate the natural behavior of the stream system. Canal leakage was added as a specified flow because its effects are easily accounted for when evaluating the effect to streamflow (which is virtually all to the lower Crooked River), but there is no practical way to remove its influence on measured groundwater levels. As described in preceding sections of this report, this enabled historical heads to be used for calibration.

Changes in groundwater storage are an important part of the basin-wide hydrologic budget. Storage changes seasonally and on an interannual basis (fig. 38). During the winter and spring, inflow from precipitation and snowmelt exceed outflows. As a consequence, stored water increases as groundwater levels rise. This can be seen as a downward movement of the storage change term (in MODFLOW convention, water going into storage is a negative value). Note that the peak movement of water into storage does not coincide with the maximum precipitation, but occurs later in the season during snowmelt. Later in the year, outflows exceed inflows and water drains from storage as groundwater levels decline. This results in the positive movement of the storage change term.

Drought cycles (and wet periods) have an effect on storage similar to seasonal changes, but on an interannual basis. The years 1996 and 1997 were more wet than average, and the storage term remained negative (water went into storage) throughout those years (fig. 38). Conversely the1990s and early 2000s included drier than average periods when the change in storage was predominantly positive (storage diminished as water-levels declined). Long-term storage changes over the simulation period account for about $200 \mathrm{ft}^{3} / \mathrm{s}$. This is consistent with the general, but spatially variable, decline in groundwater levels measured in recent decades.

Simulated evapotranspiration varies seasonally (fig. 38) averaging about 56 percent of precipitation over the simulation period; a figure consistent with other studies. Basin-wide evapotranspiration calculated by Gannett and others (2001), using the DPM (Bauer and Vaccaro, 1987) averaged 53 percent of precipitation from 1962 to 1997. Manga (1997) estimated evapotranspiration to range from 27 to 60 percent of mean annual precipitation in four catchments in the Cascade Range where mean annual precipitation ranged from 42 to $69 \mathrm{in} / \mathrm{yr}$. The basin wide average proportion of precipitation lost to evapotranspiration is heavily influenced by the large fraction of precipitation that becomes groundwater recharge in the Cascade Range. Evapotranspiration is a much larger proportion of precipitation in arid parts of the basin.

Simulated groundwater recharge from precipitation averages about $3,031 \mathrm{ft}^{3} / \mathrm{s}$ over the simulation period. This number is smaller than the value reported by Gannett and others (2001) based on the DPM, but similar to the value determined during calibration of the earlier steady-state groundwater model of Gannett and Lite (2004). Additional inflows to the groundwater system (which are specified) are canal leakage, averaging about $411 \mathrm{ft}^{3} / \mathrm{s}$, and the boundary flow of $994 \mathrm{ft}^{3} / \mathrm{s}$.

Simulated streamflow volumes are close to gaged flows and (or) calculated naturalized flows over most of the basin as previously described. Of the various components of simulated streamflow, groundwater discharge to streams explicitly represented in the model is the largest, accounting for about 55 percent of total streamflow (fig. 39). Conceptually, this includes groundwater discharging directly to streams in addition to springs along streambeds and in canyon walls. It is not possible to simulate all surface features to which groundwater discharges. Groundwater discharge that occurs in areas where streams are not explicitly represented using the MODFLOW SFR2 package is routed along the surface to the closest downslope stream reach as Dunnian flow. This would include spring discharge to wetlands, spring brooks, and small intermittent or perennial streams. Dunnian flow accounts for about 18 percent of simulated streamflow. Interflow, water moving laterally downslope in the unsaturated zone, accounts for about 26 percent of streamflow. Simulated Hortonian flow, or direct runoff over the land surface, averages only about 0.3 percent of simulated streamflow (fig. 39).

Summing direct groundwater discharge and Dunnian flow to streams indicates that groundwater makes up about 73 percent of streamflow basinwide, with the remainder being mostly interflow. Gannett and others (2003) estimated that groundwater discharge accounted for about 80 percent of streamflow of the Deschutes River near Culver and 90 percent of the flow at Madras. These estimates are slightly larger than the simulated proportions. It is possible that these earlier estimates, which were based in part on late-season flows, may include some slow interflow. 


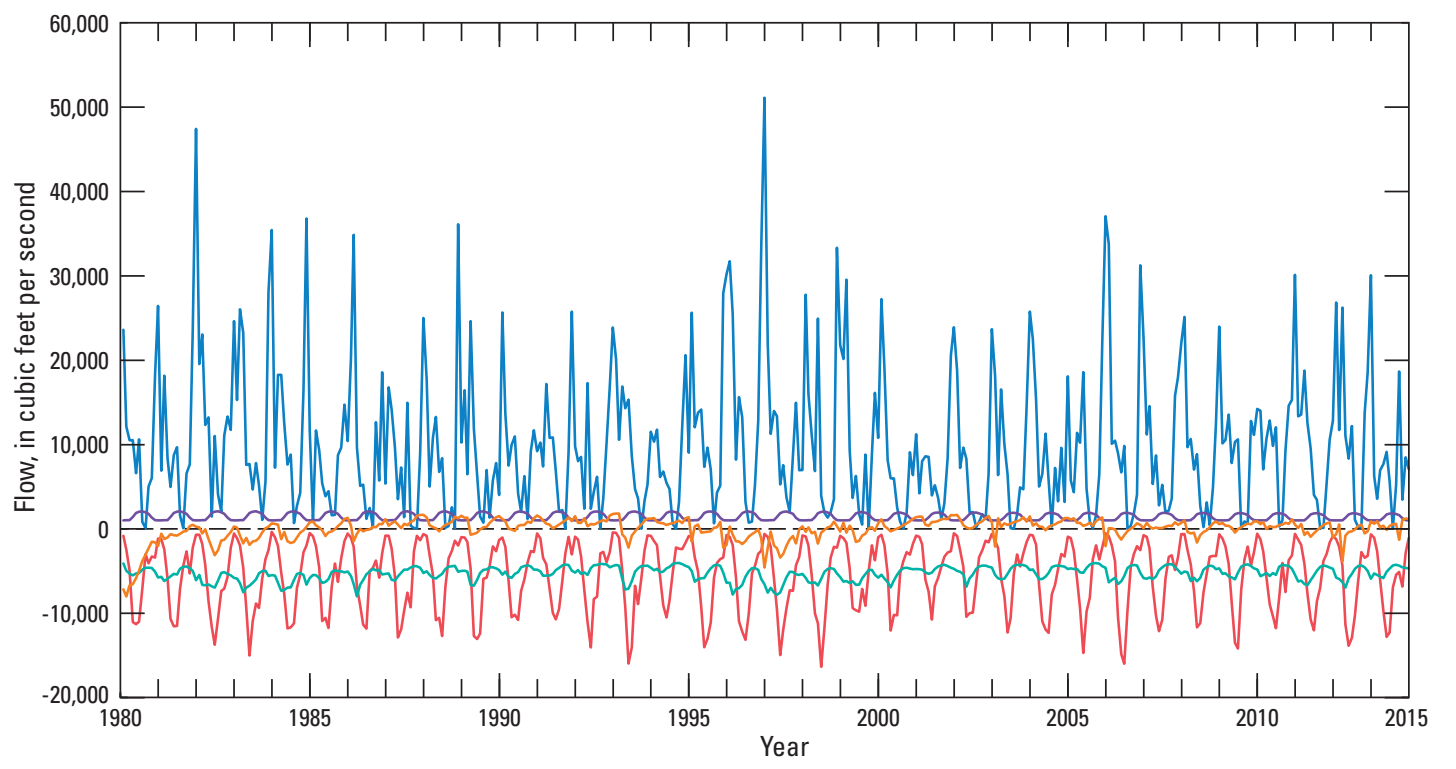

Figure 38. Monthly average simulated components of the hydrologic budget, upper Deschutes Basin, Oregon. Change in storage affected by model spin-up for first 5 years of simulation.

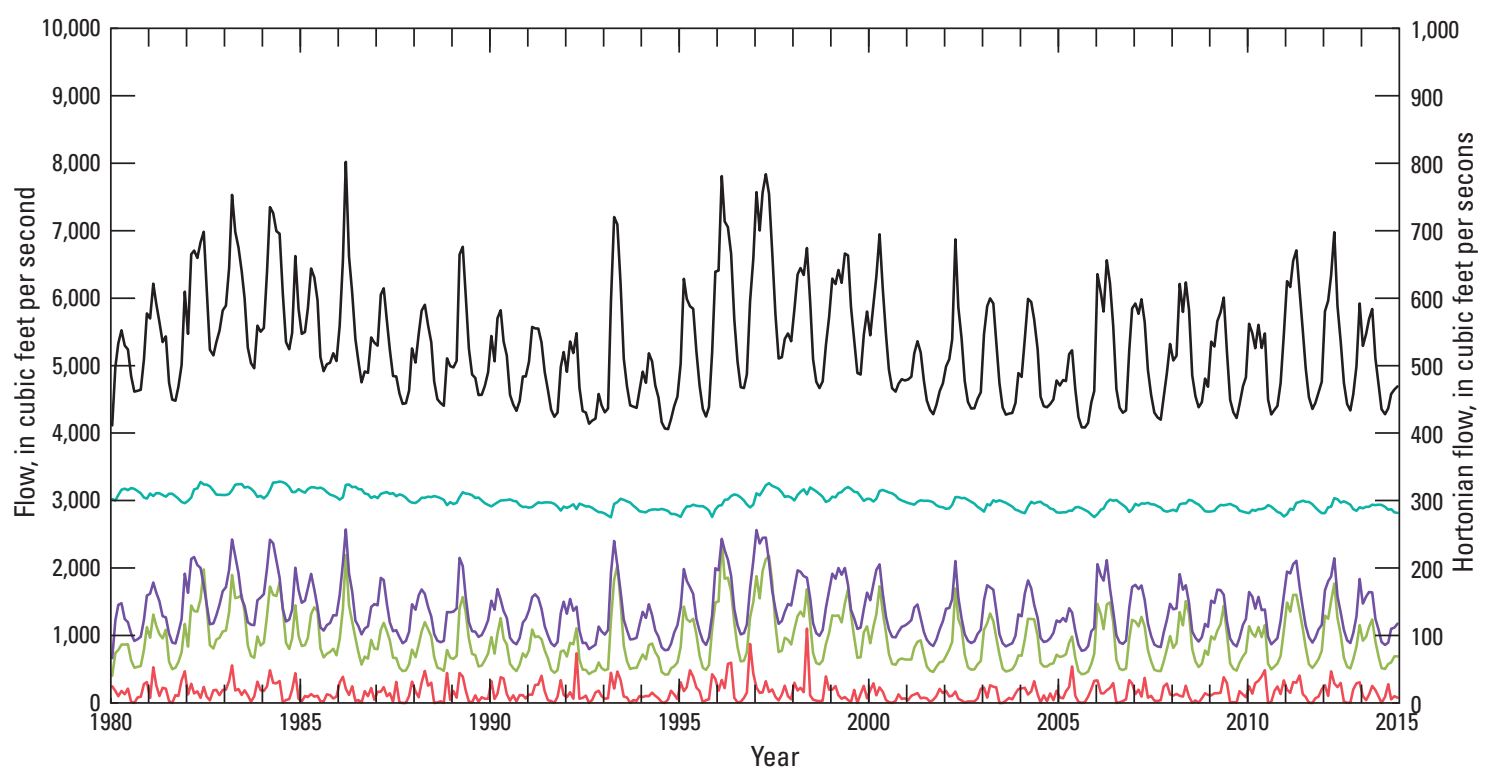

\section{EXPLANATION}

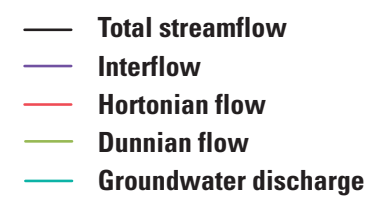

Figure 39. Simulated monthly average components of streamflow, upper Deschutes Basin, Oregon. Flows affected by model spin up during first 5 years of simulation. 


\section{Evaluating Effects of Proximity and Geologic Structure on Changes in Springs and Streamflow Resulting from Groundwater Pumping}

One of the goals of this project is to provide improved capability for evaluating the impacts of pumping on springs and streams. This is of particular interest in areas where existing and potential future pumping stresses are close to gaining streams and spring complexes. Wells can diminish streamflow by inducing additional leakage from the stream to the aquifer in areas of losing streams, or by intercepting groundwater moving toward gaining streams and springs (Barlow and Leake, 2012). The latter process is more likely in the upper Deschutes Basin.

Many factors influence impacts from pumping including the proximity of the well to springs and streams, hydraulic characteristics of geologic strata, presence of intervening geologic structure, and the depth of pumping. A thorough summary of streamflow depletion by wells discussing these factors is provided by Barlow and Leake (2012). The effects of well depth on pumping impacts in the upper Deschutes Basin are explored by Gannett and Lite (2004). The analysis presented here using the GSFLOW model focuses on the effects of faults (simulated using the Horizontal Flow Barrier package) that are known to affect groundwater flow in the area of Sisters, Oregon, and on the proximity of the pumping stress relative to known groundwater discharge areas including the upper Metolius River drainage, the headwaters of Indian Ford Creek, Whychus Creek in the McKinney Butte area, and reaches of the Deschutes and Crooked Rivers within about $10 \mathrm{mi}$ upstream of their confluence.

Three scenarios are presented with wells on either side of the Sisters fault zone and at varying distances to the discharge areas previously described. Each scenario involves adding a single well to the existing simulated pumping. In each scenario, the well is pumped at $20 \mathrm{ft}^{3} / \mathrm{s}$ (about 9,000 gallons per minute) for 7 months (April to October). This pumping rate is larger than average, but insures that the effects can be discerned from other signals. The mean annual pumping rate is $11.7 \mathrm{ft}^{3} / \mathrm{s}$. The pumping begins April 2000 and continues each year through the end of the simulation (2013). All wells used in the scenarios are in model layer 2, the layer from which the majority of the actual wells pump.

The first scenario simulates a hypothetical well about 3 mi east-southeast of Sisters, just west of the Sisters fault zone (fig. 40). The largest impact from pumping evaluated at the end of the simulation is to Whychus Creek along the east side of McKinney Butte. Smaller impacts occur to Indian Ford Creek and the Crooked River at and upstream of Opal Springs.
There are also small impacts to the Deschutes River between Lower Bridge and the confluence with Whychus Creek (fig. 40). This indicates that the Sisters fault zone, which has sufficiently low permeability to affect water-level elevations, does not totally block groundwater flow. Graphs showing the impacts with time indicate that effects to Whychus and Indian Ford Creeks have a rapid onset and are mostly manifested after about 6 or 7 years (fig. 41). Impacts on the Deschutes and Crooked Rivers have a slow onset and are still steadily increasing after 14 years of pumping at the end of the simulation. By the final year of the simulation, the 14th year of pumping, about 31 percent of the pumped water is being captured from Whychus Creek upstream of the Sisters fault zone, 15 percent from Indian Ford Creek, 17 percent from the Crooked River, and 3 percent from the Deschutes River. Although the Crooked River is more distant from the well than is the Deschutes River, the impacts are larger because of the significantly larger regional groundwater discharge. After 14 years of pumping at this location, about 73 percent of the average annual pumping is manifested in diminished streamflow as accounted for at the streamgage near Madras, with the remainder still coming primarily from changes in groundwater storage.

The second scenario simulates a well near the head of Indian Ford Creek about 3 mi south-southwest of Black Butte (fig. 42). This well is also west of the Sisters fault zone, but closer to the major groundwater discharge areas of upper Indian Ford Creeks and the headwaters of the Metolius River. As expected, impacts from pumping from this location are primarily to Indian Ford Creek and the upper Metolius River, with smaller impacts to the Crooked River (fig. 43). The onset of impacts to Indian Ford Creek and the Metolius River is rapid and largely manifested after a few years of pumping. Impacts to the Crooked River have a slow onset and are still ramping up after 14 years of pumping. In the 14th year of pumping (2013), about 39 percent of the pumped water is from reduced flows to Indian Ford Creek and another 28 percent is coming from reductions in discharge to the Metolius River upstream of the Allingham Ranger Station. Another 11 percent manifests as reduced groundwater discharge to the Metolius River drainage between the Allingham Ranger Station and the gage near Grandview (USGS streamgage 14091500). About 3 percent of the pumped water is captured from the Crooked River. The capture of flow from the Crooked River is due to stresses imposed by the pumping on deeper layers in the model. After 14 years of pumping at this location, about 89 percent of the average annual pumping is reflected in diminished streamflow as accounted for at the gage near Madras, with the remainder still coming primarily from changes in groundwater storage. The larger proportion of streamflow depletion relative to the first scenario is largely due to closer proximity to major spring areas. 


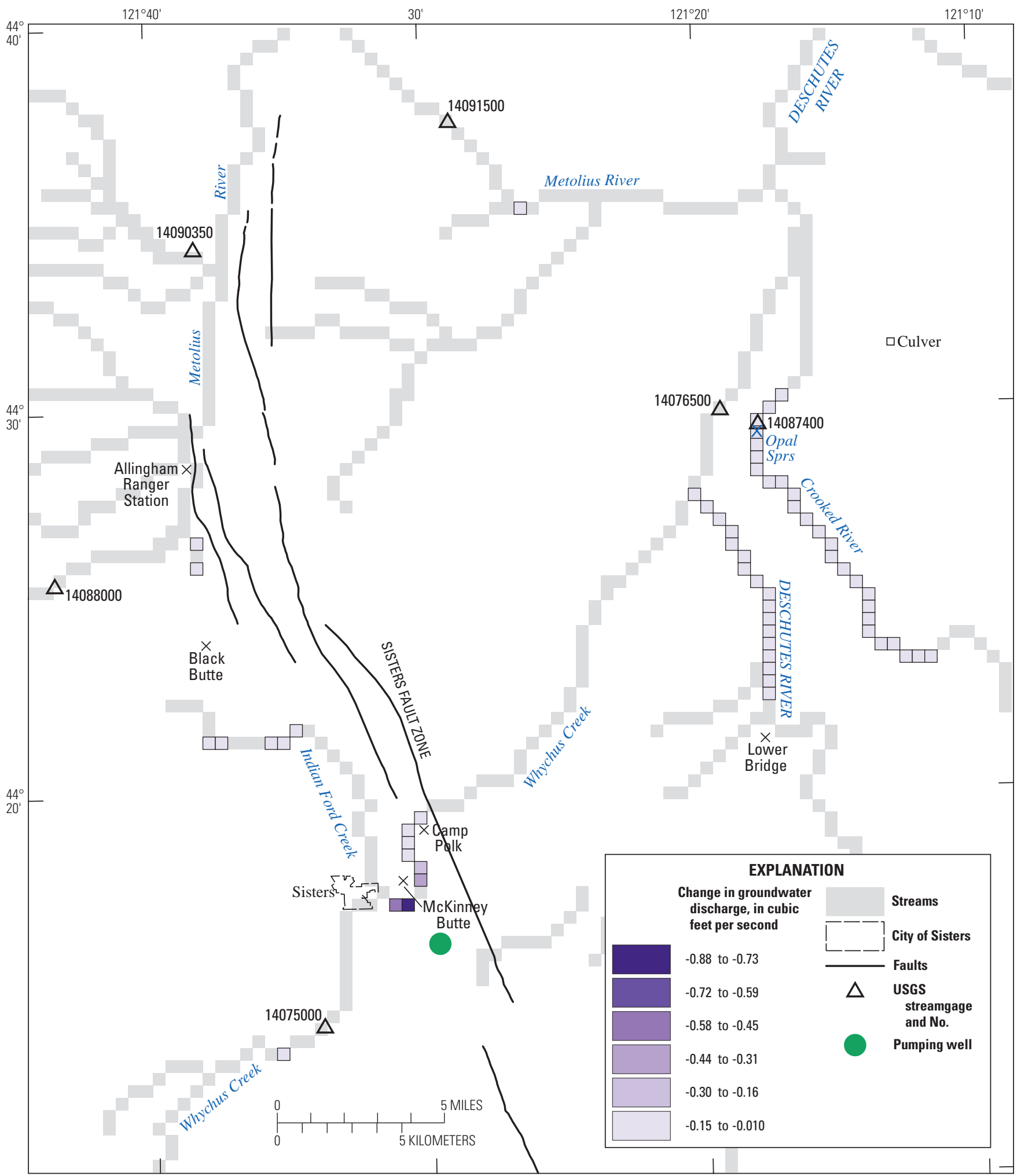

Coordinate reference system: Universal Transverse Mercator Zone 10

North, horizontal datum is North American Datum of 1983

Figure 40. Simulated average annual depletion of groundwater discharge to stream cells after 14 years of pumping 20 cubic feet per second April through October from a well about 3 miles east-southeast of Sisters, Oregon. 


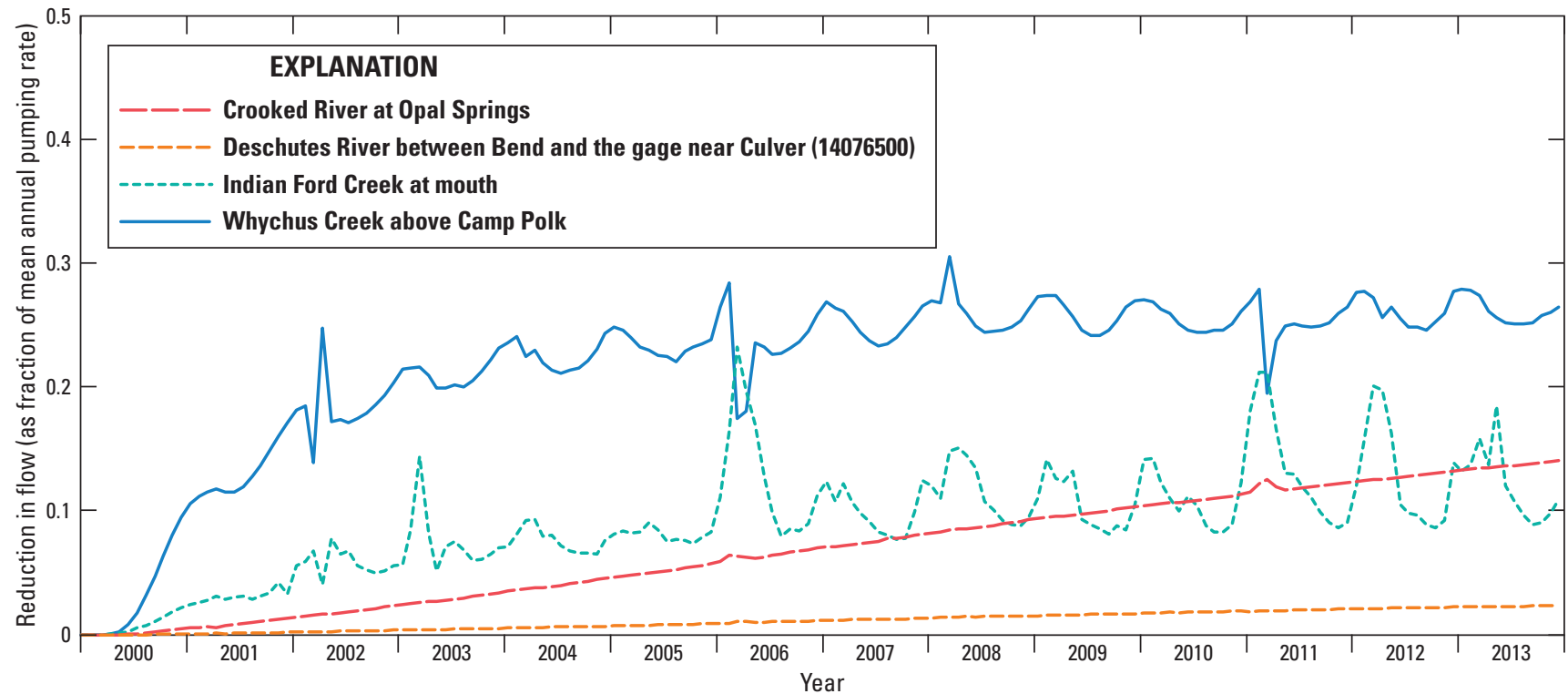

Figure 41. Simulated depletion of streamflow to heavily affected stream reaches from pumping a well about 3 miles eastsoutheast of Sisters, Oregon. Onset of pumping was April 1, 2000. 


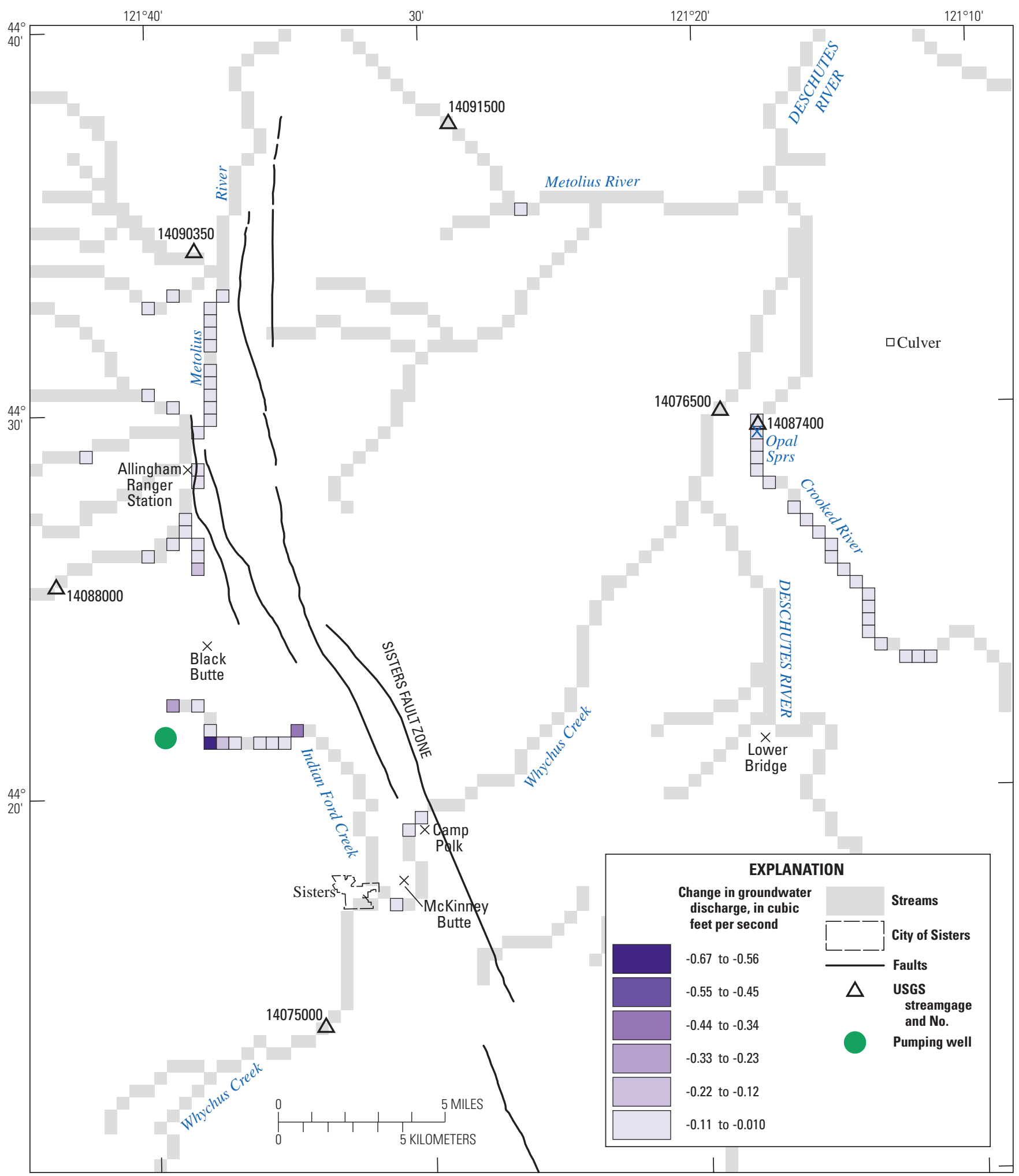

Coordinate reference system: Universal Transverse Mercator Zone 10 North, horizontal datum is North American Datum of 1983.

Figure 42. Simulated average annual depletion of groundwater discharge to stream cells after 14 years of pumping 20 cubic feet per second April through October from a well about 3 miles south-southwest of Black Butte, Oregon. 


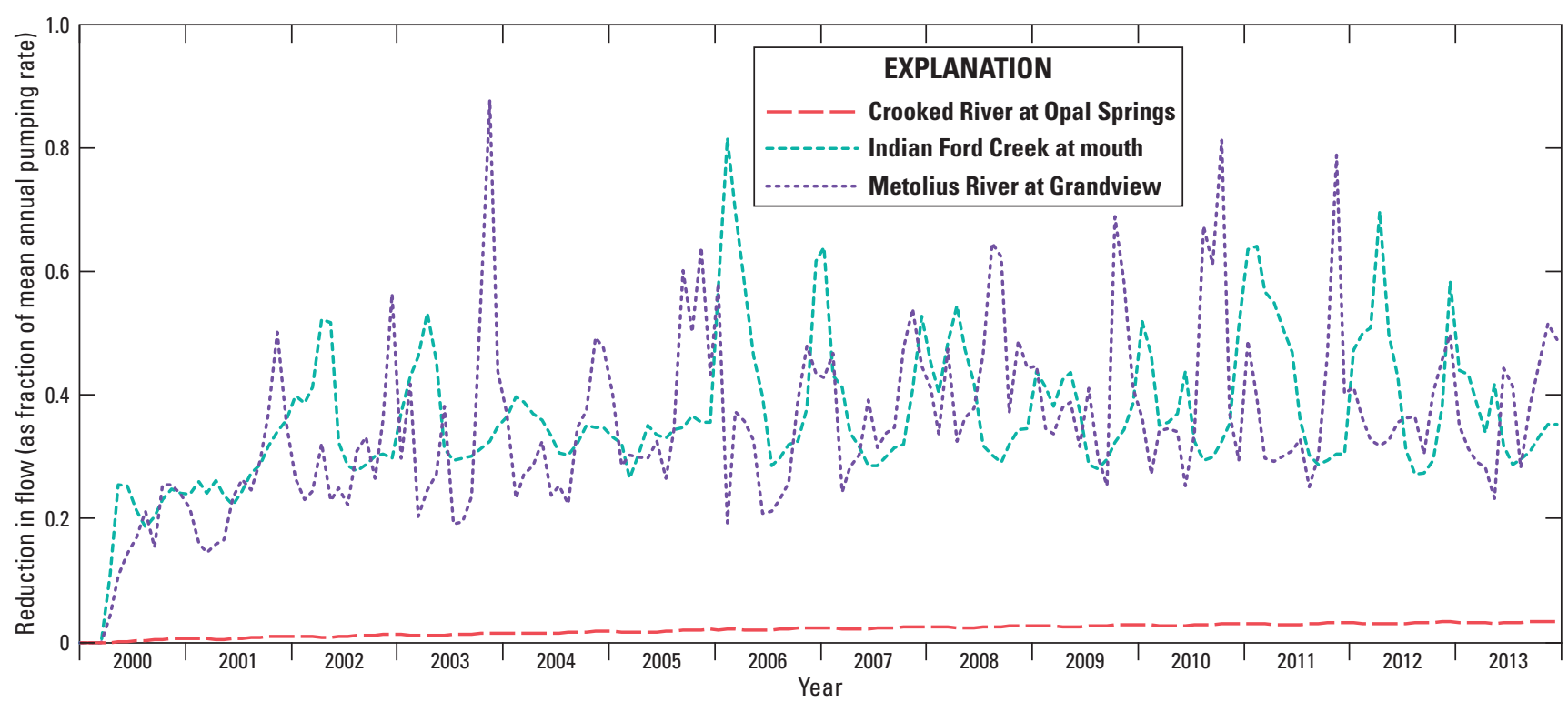

Figure 43. Simulated depletion of streamflow to heavily affected stream reaches from pumping a well about 3 miles southsouthwest of Black Butte, Oregon. Onset of pumping was April 1, 2000.

The third scenario simulated pumping from a hypothetical well about $6.6 \mathrm{mi}$ east-northeast of Sisters. This scenario differs from the first two in that the well is east of the Sisters fault zone (fig. 44). Groundwater pumped at this location is captured primarily from the Crooked River in the reach upstream of Opal Springs (fig. 44). Smaller amounts of water are captured from the Deschutes River between Lower Bridge and the gage near Culver (USGS streamgage 14076500) and from the Whychus Drainage (primarily the McKinney Butte area and the reach close to the mouth). The increase in capture from the Crooked River and decrease in capture from Whychus Creek are disproportional to the change in proximity to either stream, and are due in large part to the pumping stress being east of the Sisters fault zone. A graph of impacts with time (fig. 45) shows that the onset of impacts is gradual. Impacts to Whychus Creek and the Deschutes River are largely fully manifested after 14 years of pumping, but impacts to the Crooked River still are ramping up. In the last year of pumping, about 43 percent of the pumped water is being captured from the Crooked River, 9 percent from the Deschutes River, and about 8 percent from Whychus Creek. After 14 years of pumping at this location, only about 70 percent of the average annual pumping is manifest as diminished streamflow as accounted for at the gage near Madras, with the remainder still coming primarily from changes in groundwater storage.

These three scenarios show the large influence of well location and proximity to groundwater discharge area on the location and magnitude of impacts. The disproportionate shift in impacts to the Crooked River from the Whychus Creek drainage relative to the change in proximity to either stream in the third pumping scenario is because that well is east of the Sisters fault zone, which attenuates pumping effects. It is important to note that faults do not act as partial barriers to flow everywhere in the basin. Gannett and Lite (2004) show that increasing well depth tends to spread out the distribution of stream capture spatially and increase the timing of impacts. 


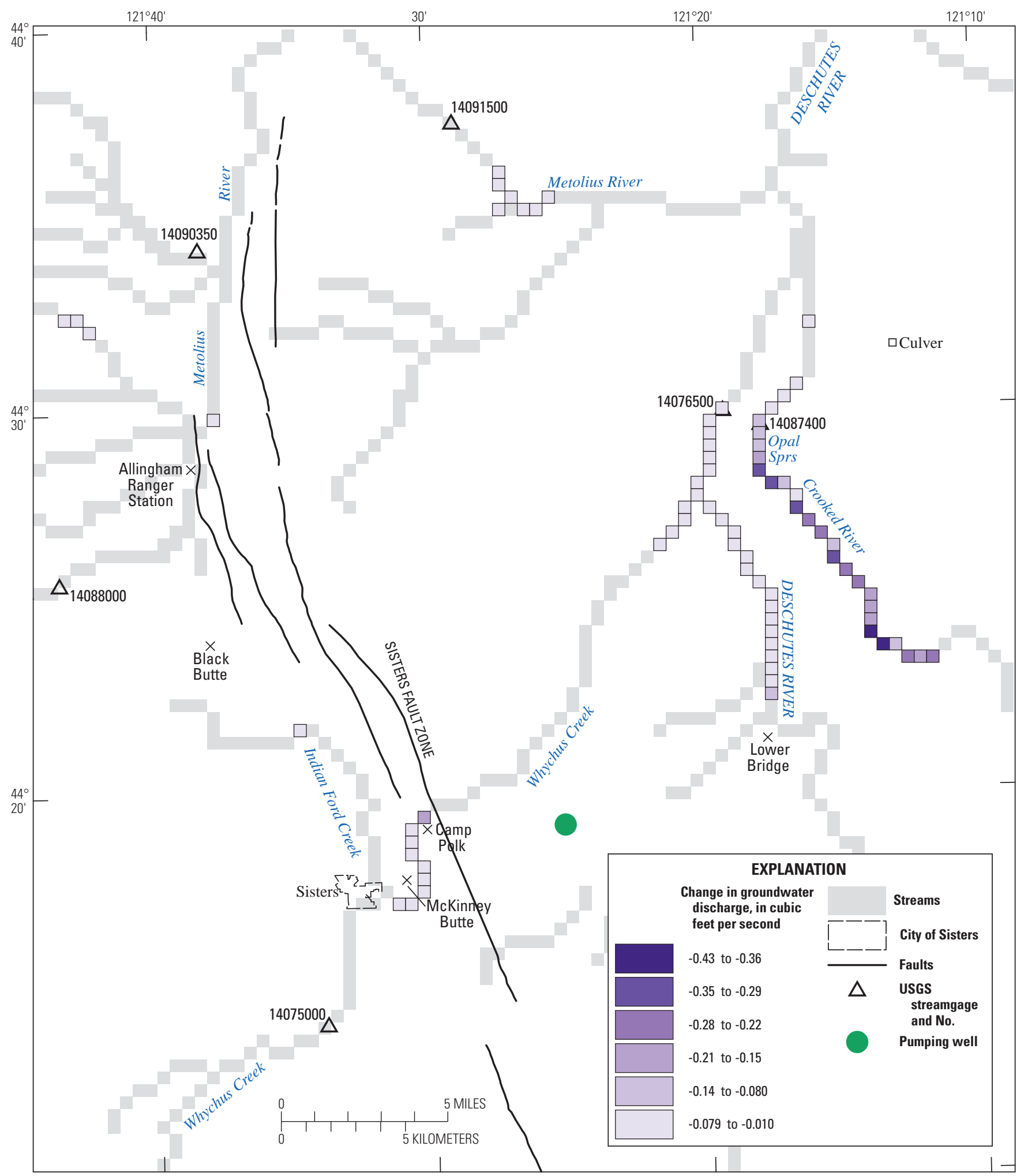

Coordinate reference system: Universal Transverse Mercator Zone 10

North, horizontal datum is North American Datum of 1983.

Figure 44. Simulated average annual depletion of groundwater discharge to stream cells after 14 years of pumping 20 cubic feet per second April through October from a well about 6.5 miles east-northeast of Sisters, Oregon. 


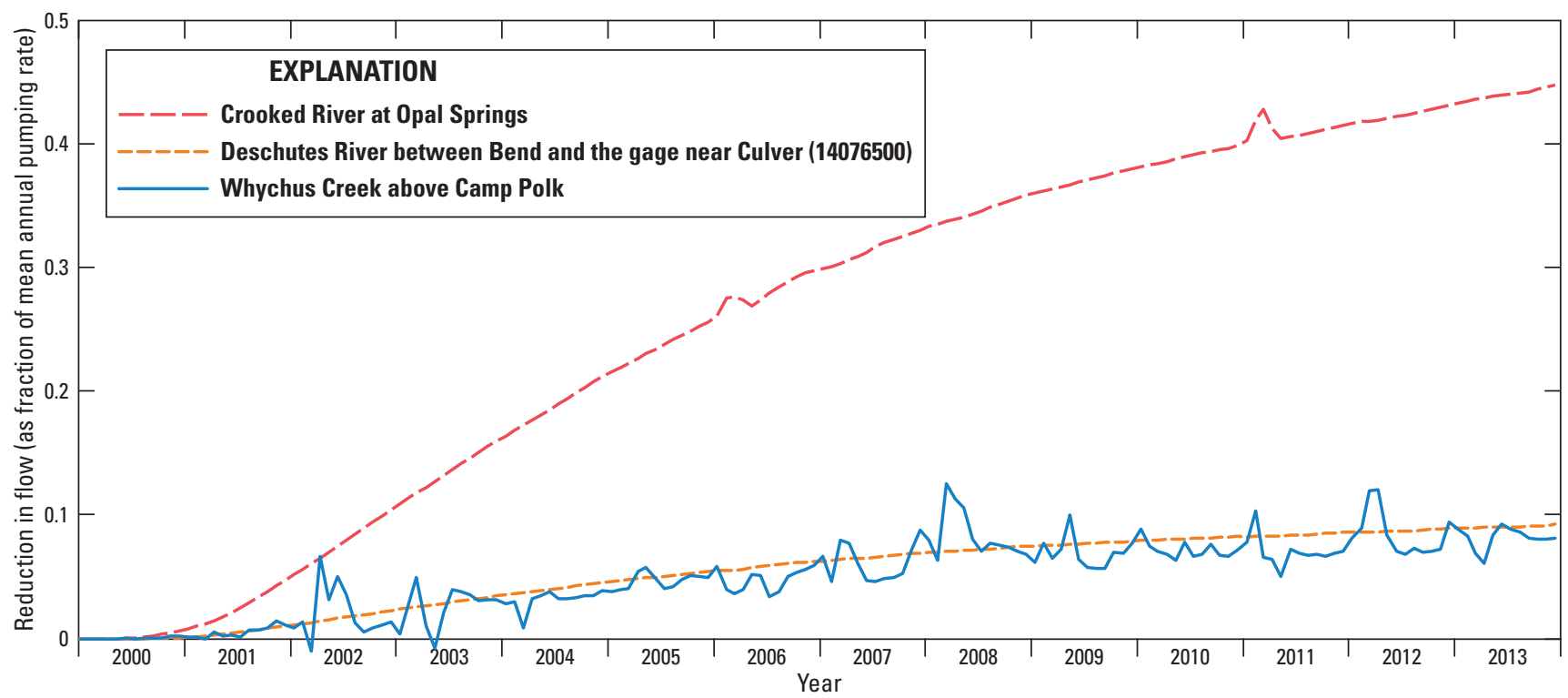

Figure 45. Simulated depletion of streamflow to heavily affected stream reaches due to pumping a well about 6.5 miles east-northeast of Sisters, Oregon. Onset of pumping was April 1, 2000.

\section{Model Limitations}

Hydrologic models are mathematical representations of infinitely complex natural systems. As such they are approximations and have inherent uncertainty and error. One source of model uncertainty is the limitations of the data used to construct and calibrate the model. There are large parts of the domain of the model described here where wells are sparse or nonexistent, and subsurface conditions are not fully understood. Subsurface conditions must be inferred from other parts of the model where geology is better known, from indirect methods such as geophysics, or inferred from the hydrologic behavior. Where measurements of subsurface hydraulic characteristics do occur, they have their own uncertainty and cannot be assumed to be generally representative.

Hydraulic head and streamflow measurements used for model calibration also have inherent uncertainty. For example, confidence intervals on streamflow measurements are commonly $\pm 5-10$ percent (Rantz, 1982). The naturalized streamflows to which simulated flows are compared have additional (unquantified) uncertainty. Hydraulic head elevations from wells in the upper Deschutes Basin are usually referenced to land-surface elevations determined from quadrangle maps with contour intervals of 20-40 ft. Both head and streamflow measurements are unevenly distributed in space and time. The meteorologic inputs to the PRMS model are derived from Daymet, which is a modeled distribution of precipitation and temperature based on widely spaced meteorological observations.
The model itself has inherent error stemming from the spatial discretization as well as the assumptions underlying the formulation of hydrologic processes. Error results from representing continuously variable aquifer properties in homogeneous zones because of the lack of subsurface information. The 1,968 ft grid spacing limits the spatial resolution of the model and ability to represent topographic complexities. Vertical discretization of the flow system into eight layers limits the ability to simulate vertical head gradients and variations with depth at any given location. The formulations of hydrologic processes commonly include simplifying assumptions.

Model error and uncertainty notwithstanding, the Deschutes GSFLOW model is a substantial improvement over the model of Gannett and Lite (2004) in its ability to accurately simulate a range of groundwater and surface-water processes at useful scales, and in the representation of the stream system. Properly used, the model can provide considerable insight into the hydrology of the upper Deschutes Basin and the response to a range of water management strategies, changes in pumping stresses, or changes in climate. Care must be taken when evaluating simulated results in areas of sparse data, in geographic areas where the fit between simulated and measured conditions is not good, or under meteorological or pumping conditions significantly outside those occurring during the calibration period. Users of the model must also be mindful of the limitations imposed by the spatial resolution. 


\section{Summary}

The Deschutes River drains much of the eastern side of the Cascade Range in central Oregon, and has geology consisting largely of permeable late Tertiary to Holocene volcanic deposits. The large annual precipitation in the Cascade Range coupled with the permeable geology results in a substantial regional groundwater system and a stream system largely groundwater dominated, with 70-90 percent of the flow coming directly from groundwater.

The upper Deschutes Basin is home to a growing population, burgeoning tourism and service industries, and associated growth in municipal and agricultural water demand. Increased demand is problematic because surface-water resources were heavily developed for irrigation by the mid-20th century and no new appropriations are allowed. In addition, some streams have legally set minimum flow requirements in place for scenic and ecological purposes. This has caused water users to turn toward groundwater to meet new demand. Water managers recognize, however, that consumptive use of groundwater will affect the already fully allocated streams in this closely coupled basin. To accommodate the growing demand, a process was developed by the Oregon Water Resources Department (OWRD) whereby new groundwater uses can be approved as long as the impacts to streams are mitigated. Such mitigation requires understanding of the spatial and temporal distribution of the impacts to streams from groundwater pumping.

Prior to this study, a groundwater model developed cooperatively by the U.S. Geological Survey (USGS) and OWRD has been used to provide insights into the spatial and temporal distribution of pumping impacts. That model has coarse grid spacing, however, and cannot resolve impacts to many important headwater streams or simulate flows to some environmentally sensitive spring areas. Moreover, the model was not well suited for efficiently exploring the hydrologic response to climate change or extended drought, an area of increasing interest and need.

To remedy these shortcomings, a new model has been developed that simulates both surface-water and groundwater flow using the USGS Coupled Groundwater and Surface-Water Flow Model (GSFLOW) which combines a surface-water model, Precipitation Runoff Modeling System (PRMS), and the Modular Groundwater Flow Model (MODFLOW). GSFLOW simulates surface processes (such as snowpack accumulation and melting, evapotranspiration, and soil moisture), streamflow, and groundwater flow. The new model was based on the existing USGS regional groundwater model, but with refined spatial and temporal resolution allowing better simulation of headwater streams and spring complexes.
The upper Deschutes Basin GSFLOW model is set up to simulate natural conditions, meaning that the effects of storage reservoirs and diversions are not simulated. The effects of groundwater pumping and artificial groundwater recharge by leaking irrigation canals are simulated. Principal model inputs include spatially distributed daily precipitation and temperature data from Daymet, monthly estimates of municipal and irrigation pumping, and monthly estimates of irrigation canal leakage.

The model was calibrated comparing simulated and measured water levels from 800 wells, 144 of which have time series of 10 or more measurements. Data from 21 gage locations in the basin were available for calibration of simulated streamflow. Flows at 14 of these sites are heavily affected by reservoirs and (or) diversions, which limits the usefulness of gage data directly for calibration. Fortunately, the Bureau of Reclamation has calculated naturalized flow time series for these sites by removing the effects of reservoir storage and evaporation, diversions, and seepage. Simulated flows were compared to these naturalized flows at these locations. Surface processes simulated by the PRMS model were calibrated using national datasets of simulated variables such as potential evapotranspiration and solar radiation, as well as measurements at specific SNOTEL and AgriMet sites in the basin.

The calibrated model does a good job of simulating hydraulic head elevation over the 5,000 ft range heads observed across the model domain. The average and median head residuals are -22.6 and $-15.4 \mathrm{ft}$, respectively, and the standard deviation is $116 \mathrm{ft}$. Temporal variations in heads are also well simulated, capturing the effects of external stresses such as drought cycles (and intervening wet periods), changes in pumping and canal leakage, and seasonal variations in recharge. The fit to daily streamflow is good for main-stem streams such as the Metolius and Crooked Rivers, and the lower part of the Deschutes River. The fit to seasonal peaks in streamflow is off by 1-2 months in parts of the southernmost basin. Annual streamflow is generally good throughout the basin, with the exception of Tumalo and Whychus Creeks and the Little Deschutes River. The geographic distributions of groundwater discharge to streams and stream leakage to the aquifer system are well simulated. Simulation results confirm results of earlier studies showing the large proportion of streamflow originating as groundwater either as direct discharge to streams or from Dunnian flow (representing spring flow to streams that are not explicitly simulated).

Use of the model is demonstrated by exploring the influence of proximity and geologic structure on the impacts to streams from groundwater pumping. Pumping scenarios were run for three hypothetical wells within 12 miles of each 
other. The wells have differing proximity to spring complexes and groundwater discharge areas in the northwestern part of the study area near Sisters, Oregon, and on different sides of the Sisters fault zone. Measured head changes across the Sisters fault zone indicate it is a region of low permeability affecting groundwater flow. The scenarios demonstrate that well location is a major factor influencing the distribution of capture of water from streams and springs by groundwater pumping. The scenarios also demonstrate the considerable influence geologic structure can have on the propagation of pumping stresses in a basin. Scenarios such as these can provide useful insights into the possible impacts from proposed groundwater pumping.

Like all models, the upper Deschutes Basin GSFLOW model has inherent uncertainty and error. Sources include uncertainty in the knowledge of subsurface conditions in the basin caused by, among other things, the lack of subsurface data over large parts of the basin; and uncertainty in hydraulic head and streamflow data, including the calculated naturalized flows. Model error results from discretization and representing continuously variable hydraulic properties as large homogeneous zones, and in the simplifying assumptions in the formulation of hydrologic processes. Model uncertainty and fit are spatially variable. Regardless, the model simulates well the observed hydraulic head data (both spatially and temporally), and streamflow, particularly to the main streams. Annual water balances are reasonable for most streams throughout the model.

The model provides useful insights into the hydrology of the upper Deschutes Basin, and should be of considerable use exploring effects of different water management strategies, changes in pumping stresses or canal leakage, and the effects of extended drought or climate change. Users of the model must be mindful of model limitations, geographic variability in the model fit, and limitations due to grid resolution.

\section{Acknowledgments}

This project benefitted from many individuals who generously shared their time, expertise, and insights. Paul Barlow with the USGS Office of Groundwater was instrumental in procuring seed funding to initiate the project. Rich Niswonger and Steve Regan were key in implementing GSFLOW in this complex and unique basin, and provided great (and prompt) technical support throughout the project. Jen Johnson with the Bureau of Reclamation provided information on the naturalized flows and shared many insights into the hydrology of the basin. Mike Relf, also with the Bureau of Reclamation, was instrumental in securing funding to assist with model calibration, and setting it up for future use in climate studies. Erick Burns helped with early parameter-estimation efforts with the MODFLOW model, and wrote many key Python scripts used for pre- and post-processing.

\section{References Cited}

Allen, J.E., 1966, The Cascade Range volcano-tectonic depression of Oregon, in Benson, G.T., ed., Transactions of the Lunar Geological Field Conference, Bend, Oregon, August 1965: Oregon Department of Geology and Mineral Industries, p. 21-23.

Anderson, M.P., and Woessner, W.W., 1992, Applied ground-water modeling: Academic Press Inc., San Diego, California, $381 \mathrm{p}$.

Barlow, P.P., and Leake, S.A., 2012, Streamflow depletion by wells-Understanding and managing the effects of groundwater pumping on streamflow: U.S. Geological Survey Circular 1376, 84 p., https://pubs.er.usgs.gov/ publication/cir1376.

Bauer, H.H., and Vaccaro, J.J., 1987, Documentation of a deep percolation model for estimating ground-water recharge: U.S. Geological Survey Open-File Report 86-536, 180 p., https://pubs.er.usgs.gov/publication/ofr86536.

Blackwell, D.D., 1992, Thermal results of the Santiam Pass 77-24 drill hole, in Hill, B.E., ed., Geology and geothermal resources of the Santiam Pass area of the Oregon Cascade Range, Deschutes, Jefferson and Linn Counties, Oregon: Oregon Department of Geology and Mineral Industries Open-File Report O-92-3, p. 37-52.

Blackwell, D.D., and Priest, G.R., 1996, Comment on, in Ingebritsen, S.E., Sherrod, D.R,. and Mariner, R.H., Rates and patterns of groundwater flow in the Cascade Range volcanic arc and the effect on subsurface temperatures: Journal of Geophysical Research, v. 101, no. B8, p. $17,561-17,568$.

Bonneville Power Administration, 2017, 2010 Modified Streamflows: Bonneville Power Administration online database, accessed March 5, 2017, at https://www.bpa.gov/ power/streamflow/.

Blodgett, D.L., Booth, N.L., Kunicki, T.C., Walker, J.L., and Viger, R.J., 2011, Description and testing of the Geo Data Portal-Data integration framework and web processing services for environmental science collaboration: U.S. Geological Survey Open-File Report 2011-1157, 9 p.

Bureau of Reclamation, 1991a, Canal lining demonstration project-Canal ponding tests and seepage rate determinations: Denver, Colorado, Pacific Northwest Region Office, 10 p.

Bureau of Reclamation, 1991b, Geology report-Central Oregon canal system, upper Deschutes River Basin water conservation project, Oregon: Boise, Idaho, Division of Design and Construction, 80 p. 
Bureau of Reclamation, 1993, Water loss analysis-Upper Deschutes River Basin water conservation project: Boise, Idaho, Pacific Northwest Region, 12 p.

Bureau of Reclamation, 2016, Pacific Northwest region, AgriMet: Bureau of Reclamation AgriMet database, accessed November 7, 2016, at https://www.usbr.gov/pn/ agrimet/.

Bureau of Reclamation, 2017, Development of a daily water management model of the Deschutes River, Oregon, using RiverWare: U.S. Department of the Interior, Bureau of Reclamation, Northwest Region, Boise, Idaho, 46 p. plus appendix.

Conrey, R.M., 1985, Volcanic stratigraphy of the Deschutes Formation-Green Ridge to Fly Creek—north-central Oregon: Corvallis, Oregon State University, M.S. thesis, 349 p.

Couch, R., and Foote, R., 1985, The Shukash and La Pine basins-Pleistocene depressions in the Cascade Range of central Oregon [abs]: EOS (American Geophysical Union Transactions), v. 66, no. 3, p. 24.

Cuenca, R.H., Nuss, J.L., Martinez-Cob, Antonio, and Katul, G.G., 1992, Oregon crop water use and irrigation requirements: Oregon State University Extension Miscellaneous 8530, 184 p.

Ely, D.M., Burns, E.R., Morgan, D.S., and Vaccaro, J.J., 2014, Numerical simulation of groundwater flow in the Columbia Plateau Regional Aquifer System, Idaho, Oregon, and Washington (ver. 1.1, January 2015): U.S. Geological Survey Scientific Investigations Report 2014-5127, 90 p., http://dx.doi.org/10.3133/sir20145127.

Farnsworth, R.K., Thompson, E.S., and Peck, E.L, 1982, Evaporation atlas for the contiguous 48 United States: Washington D.C., National Oceanic and Atmospheric Administration, NOAA Technical Report NWS 33, p. 27.

Farnsworth, R.K., and Thompson, E.S., 1982, Mean monthly, seasonal, and annual pan evaporation for the United States: Washington D.C., National Oceanic and Atmospheric Administration, NOAA Technical Report NWS 34, p. 85.

Fry, J., Xian, G., Jin, S., Dewitz, J., Homer, C., Yang, L., Barnes, C., Herold, N., and Wickham, J., 2011, Completion of the 2006 National Land Cover Database for the Conterminous United States: PE\&RS, v. 77, no. 9, p. 858-864.

Gannett, M.W., and Lite, K.E., Jr., 2004, Simulation of regional ground-water flow in the upper Deschutes Basin, Oregon: U.S. Geological Survey Water-Resources Investigations Report 03-4195, 84 p., https://pubs.er.usgs. gov/publication/wri034195.
Gannett, M.W., and Lite, K.E., Jr., 2013, Analysis of 19972008 groundwater level changes in the upper Deschutes Basin, Central Oregon: U.S. Geological Survey Scientific Investigations Report 2013-5092, 34 p., http://pubs.usgs. gov/sir/2013/5092.

Gannett, M.W., Lite, K.E., Jr., Morgan, D.S., and Collins, C.A., 2001, Ground-water hydrology of the upper Deschutes Basin, Oregon: U.S. Geological Survey WaterResources Investigations Report 00-4162, 77 p., https:// pubs.er.usgs.gov/publication/wri20004162.

Gannett, M.W., Manga, Michael, and Lite, K.E., Jr., 2003, Groundwater hydrology of the upper Deschutes Basin and its influence on streamflow, in O’Connor, J.E., and Grant, G.E., eds., A peculiar river-Geology, geomorphology, and hydrology of the Deschutes River, Oregon: American Geophysical Union Water Science and Application No. 7, p. 31-49, http://dx.doi.org/10.1029/007ws04.

Hackett, J.A., 2011, Hydrogeology of the McKinney Butte area, Sisters, Oregon: Portland, Oregon, Portland State University, M.S. Thesis, 167 p. plus appendices.

Harbaugh, A.W., 2005, MODFLOW-2005, The U.S. Geological Survey modular ground-water model-The Ground-Water Flow Process: U.S. Geological Survey Techniques and Methods 6-A16, variously paginated, https://pubs.er.usgs.gov/publication/tm6A16.

Henshaw, F.F., Lewis, J.H., and McCaustland, E.J., 1914, Deschutes River, Oregon, and its utilization: U.S. Geological Survey Water Supply Paper 344, 200 p.

Henson, W.R., Medina, R.L., Mayers, C.J., Niswonger, R.G., and Regan, R.S., 2013, CRT_Cascade Routing Tool to define and visualize flow paths for grid-based watershed models: U.S. Geological Survey Techniques and Methods 6-D2, 28 p., https://pubs.er.usgs.gov/publication/tm6D2.

Hsieh, P.A., and Freckleton, J.R., 1993, Documentation of a computer program to simulate horizontal-flow barriers using the U.S. Geological Survey modular three- dimensional finite-difference ground-water flow model: U.S. Geological Survey Open-File Report 92-477, 32 p., https://pubs.er.usgs. gov/publication/ofr92477.

Ingebritsen, S.E., Sherrod, D.R., and Mariner, R.H., 1992, Rates and patterns of groundwater flow in the Cascade Range volcanic arc, and the effect on subsurface temperatures: Journal of Geophysical Research, v. 97, no. B4, p. 4,599-4,627.

Johnson, D.M., Peterson, R.R., Lycan, D.R., Sweet, J.W., and Neuhaus, M.E., 1985, Atlas of Oregon Lakes: Corvallis, Oregon, Oregon State University Press, 317 p. 
Knowles, N., Dettinger, M.D., and Cayan, D.R., 2006, Trends in snowfall versus rainfall in the western United States: Journal of Climate, v. 19, n. 18, p. 4,545-4,559.

Lite, K.E., Jr., and Gannett, M.W., 2002, Geologic framework of the regional ground-water flow system in the upper Deschutes Basin Oregon: U.S. Geological Survey WaterResources Investigations Report 02-4015, 44 p., https:// pubs.er.usgs.gov/publication/wri024015.

Manga, Michael, 1996, Hydrology of spring-dominated streams in the Oregon Cascades: Water Resources Research, v. 32, no. 8, p. 2,435-2,439.

Manga, Michael, 1997, A model for discharge in springdominated streams and implications for the transmissivity and recharge of Quaternary volcanics in the Oregon Cascades: Water Resources Research, v. 33, no. 8, p. 1,813-1,822.

Mantua N.J., Hare, S.J., Zhang, Yuan, Wallace, J.M., and Francis, R.C., 1997, A Pacific interdecadal climate oscillation with impacts on salmon production: Bulletin of the American Meteorology Society, v. 78, no. 6, p. 1,069-1,079.

Markstrom, S.L., Niswonger, R.G., Regan, R.S., Prudic, D.E., and Barlow, P.M., 2008, GSFLOW-Coupled ground-water and surface-water flow model based on the integration of the Precipitation-Runoff Modeling System (PRMS) and the Modular Ground-Water Flow Model (MODFLOW-2005): U.S. Geological Survey Techniques and Methods 6-D1, 240 p., https://pubs.er.usgs.gov/publication/tm6D1.

Markstrom, S.L., Regan, R.S., Hay, L.E., Viger, R.J., Webb, R.M.T., Payn, R.A., and LaFontaine, J.H., 2015, PRMS-IV, the precipitation-runoff modeling system, version 4: U.S. Geological Survey Techniques and Methods, book 6, chap. B7, 158 p., http://dx.doi.org/10.3133/tm6B7.

Mayer, T.D., and Naman, S.W., 2011, Streamflow response to climate as influenced by geology and elevation. Journal of the American Water Resources Association, v. 47, no. 4, p. 724-738.

McDonald, M.G., and Harbaugh, A.W., 1988, A modular three-dimensional finite-difference ground-water flow model: U.S. Geological Survey Techniques of WaterResources Investigations, Book 6, Chapter A-1, 586 p., https://pubs.er.usgs.gov/publication/twri06A1.

Morgan, D.S., Hinkle, S.R., and Weick, R.J., 2007, Evaluation of approaches for managing nitrate loading from on-site wastewater systems near La Pine, Oregon: U.S. Geological Survey Scientific Investigations Report 2007-5237, 66 p., https://pubs.er.usgs.gov/publication/sir20075237.
Mote, P.W., Hamlet, A.F., Clark, M.P., Lettenmaier, D.P., 2005, Declining mountain snowpack in western North America: Bulletin of the American Meteorological Society, v. 86 , no. 1 , p. 39-44.

National Renewable Energy Laboratory, 2017, Geospatial Data Science_-Solar data: National Renewable Energy Laboratory solar database for the United States, accessed February 26, 2017, at http://www.nrel.gov/gis/data-solar. $\mathrm{html} /$.

Natural Resource Conservation Service, 2016, Snow telemetry (SNOTEL) and snow course data and products: National Weather and Climate Center database, accessed November 7, 2016, at https://www.wcc.nrcs.usda.gov/ snow/.

Niswonger, R.G., Panday, Sorab, and Ibaraki, Motomu, 2011, MODFLOW-NWT, A Newton formulation for MODFLOW-2005: U.S. Geological Survey Techniques and Methods 6-A37, 44 p., https://pubs.er.usgs.gov/publication/ tm6A37.

Niswonger, R.G., and Prudic, D.E., 2005, Documentation of the Streamflow-Routing (SFR2) Package to include unsaturated flow beneath streams-A modification to SFR1: U.S. Geological Survey Techniques and Methods 6-A13, 50 p., https://pubs.er.usgs.gov/publication/tm6A13.

O’Connor, J.E., Grant, G.E., and Haluska, T.L., 2003, Overview of geology, hydrology, geomorphology, and sediment budget of the Deschutes river basin, Oregon, in O’Connor, J.E., and Grant, G.E., eds., A peculiar riverGeology, geomorphology, and hydrology of the Deschutes River, Oregon: American Geophysical Union Water Science and Application Series No. 7, p. 7-29, http://dx.doi. org/10.1029/007ws04.

Oregon Water Resources Department, 1965, Compilation of surface water records of Oregon: Oregon Water Resources, Salem, Oregon, 219 p.

Oregon Water Resources Department, 2017, Water level data and hydrographs: Oregon Water Resources Department database, accessed March 6, 2017, at http://www.oregon. gov/owrd/pages/gw/well_data.aspx.

PRISM Climate Group, 2017, 30-year normals: PRISM Climate Group database, Oregon State University, accessed March 27, 2017, http://www.prism.oregonstate.edu/ normals/.

Rantz, S.E., 1982, Measurement and computation of streamflow_Volumes I and II: U.S. Geological Survey Water-Supply Paper 2175, 631 p. 
Redmond, K.T., and Koch, R.W., 1991, Surface climate and streamflow variability in the western United States and their relationship to large-scale circulation indices: Water Resources Research, v. 27, no. 9, p. 2,381-2,399.

Robison, J.H., Forcella, L.S., and Gannett, M.W., 1981, Data from geothermal test wells near Mt. Hood, Oregon: U.S. Geological Survey Open-File Report 81-1002, 24 p., https:// pubs.er.usgs.gov/publication/ofr811002.

Russell, I.C., 1905, Geology and water resources of central Oregon: U.S. Geological Survey Bulletin 252, 138 p.

Sceva, J.E., 1960, A brief description of the ground water resources of the Deschutes River Basin, Oregon: Salem, Oregon, Oregon State Engineer (now Oregon Water Resources Department), 55 p.

Sceva, J.E., 1968, Liquid waste disposal in the lava terrane of central Oregon: U.S. Department of the Interior, Federal Water Pollution Control Administration, Technical Projects Branch Report No. FR-4, 66 p., plus a 96 page appendix.

Sherrod, D.R., Taylor, E.M., Ferns, M.L., Scott, W.E., Conrey, R.M., and Smith, G.A., 2004, Geologic map of the Bend 30- × 60-minute quadrangle, Central Oregon: U.S. Geological Survey Geologic Investigations Series Map I-2683, 2 sheets, 49 p. pamphlet, https://pubs.er.usgs.gov/ publication/i2683.

Smith, G.A., 1986, Stratigraphy, sedimentology, and petrology of the Neogene rocks in the Deschutes basin, central Oregon-A record of continental-margin volcanism and its influence on fluvial sedimentation in an arc-adjacent basin: Corvallis, Oregon, Oregon State University, Ph.D. dissertation, 464 p. (also Richland, Washington, Rockwell Hanford Operations Report RHO-SA-555P, 260 p.)

Smith, G.A., Snee, L.W., and Taylor, E.M., 1987, Stratigraphic, sedimentologic, and petrologic record of late Miocene subsidence of the central Oregon High Cascades: Geology, v. 15, no. 5, p. 389-392.

Stearns, H.T., 1931, Geology and water resources of the middle Deschutes River Basin, Oregon: U.S. Geological Survey Water-Supply Paper 637-D, 220 p.
Tague, C., Grant, G., Farrell, M., Choate, J., and Jefferson, A., 2008, Deep groundwater mediates streamflow response to climate warming in the Oregon Cascades: Climatic Change, v. 86, no. 1, p. 189-210.

Taylor, E.M., 1981, Central High Cascade roadside geologyBend, Sisters, McKenzie Pass, and Santiam Pass, Oregon, in Johnston, D.A., and Donnelly-Nolan, J.M., eds., Guides to some volcanic terranes in Washington, Idaho, Oregon, and northern California: U.S. Geological Survey Circular 838, p. 55-83.

Taylor, G.H., 1993, Normal annual precipitation, State of Oregon: Corvallis, Oregon State University, Oregon Climate Service, map.

Thornton, P.E., Thornton, M.M., Mayer, B.W., Wei, Y., Devarakonda, R., Vose, R.S., and Cook, R.B., 2016, Daymet-Daily surface weather data on a 1-km grid for North America, Version 3: Oak Ridge National Laboratory Distributed Active Archive Center (ORNL DAAC), accessed June 2014 at http://dx.doi.org/10.3334/ ORNLDAAC/1328.

U.S. Geological Survey, 2012, National Elevation Dataset (NED) 10-meter resolution arc info GRID: National Elevation Dataset release notes, accessed February 27, 2017, at https://nationalmap.gov/3DEP/documents/NED_ Release_Notes_Apr12.pdf.

U.S. Geological Survey, 2017, USGS Water Data for the Nation: National Water Information System, Web Interface, accessed at various times, at https://waterdata.usgs.gov/ nwis.

Waibel, M.S., Gannett, M.W., Chang, H., and Hulbe, C.L, 2013 Spatial variability of the response to climate change in regional groundwater systems-Examples from simulations in the Deschutes Basin, Oregon: Journal of Hydrology, v. 486, p. 187-201, http://dx.doi.org/10.1016/j. jhydrol.2013.01.019. 
Publishing support provided by the U.S. Geological Survey Science Publishing Network, Tacoma Publishing Service Center

For more information concerning the research in this report, contact the Director, Oregon Water Science Center

U.S. Geological Survey

2130 SW 5th Avenue

Portland, Oregon 97201

https://or.water.usgs.gov 
里

票

⿳亠丷厂

㝠

$\frac{\pi}{\infty}$

里

흘.

옹

옴

른

蛋

를

ㄴ

苛

隻

余

끙

言

듬

용

产

思

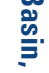

옹

!

cs

힌

言:

స్ํำ

禺.

ิㅟำ

훙.

ग0

음

N

齐 